\title{
RETENTION OF A MODEL PATHOGEN \\ IN A POROUS MEDIA BIOFILM
}

\author{
by
}

Wesley James Bauman

A thesis submitted in partial fulfillment of the requirements for the degree

of

Master of Science

in

Environmental Engineering

Montana State University

Bozeman, Montana State University

April 2007 


\section{(C) COPYRIGHT}

by

Wesley James Bauman

2007

All Rights Reserved 


\section{APPROVAL \\ of a thesis submitted by \\ Wesley James Bauman}

This thesis has been read by each member of the thesis committee and has been found to be satisfactory regarding content, English usage, format, citations, bibliographic style, and consistency, and is ready for submission to the Division of Graduate Education.

\section{Dr. Anne Camper}

Approved for the Department of Civil Engineering

Dr. Brett Gunnink

Approved for the Division of Graduate Education

Dr. Carl A. Fox 


\section{STATEMENT OF PERMISSION TO USE}

In presenting this thesis in partial fulfillment of the requirements for a master's degree at Montana State University, I agree that the Library shall make it available to borrowers under rules of the Library.

If I have indicated my intention to copyright this thesis by including a copyright notice page, copying is allowable only for scholarly purposes, consistent with "fair use" as prescribed in the U.S. Copyright Law. Requests for permission for extended quotation from or reproduction of this thesis in whole or in parts may be granted only by the copyright holder.

Wesley James Bauman

April 2007 


\section{ACKNOWLEDGEMENTS}

This research was funded by the Army Research Office.

In $2001 \mathrm{I}$ had the pleasure of being introduced to environmental engineering as well as the Center for Biofilm Engineering (CBE) by Dr. Warren Jones. Since that time he has been an invaluable mentor and patient sounding board both as an undergraduate advisor and a graduate committee member. While working at the CBE as an undergraduate intern I had an opportunity to reunite with my first undergraduate advisor Dr. Anne Camper, working for one of her graduate students, Alex Bargmeyer. Alex truly went out of his way to teach me about engineering research and I always appreciated his

guidance. The support I received from Alex, Anne, Warren and the entire CBE convinced me that pursuing a Masters' degree at Montana State University would be a rewarding experience. I cannot thank Anne enough for the opportunity she gave me to pursue that goal and for her unwavering support as the chair of my graduate committee. I would also like to thank Andreas Nocker for sharing his wisdom and positivity while helping me learn to perform quantitative PCR. Lastly I would like to thank my family; their passion for education and constant encouragement are always a blessing. Thank you all very much. 
TABLE OF CONTENTS

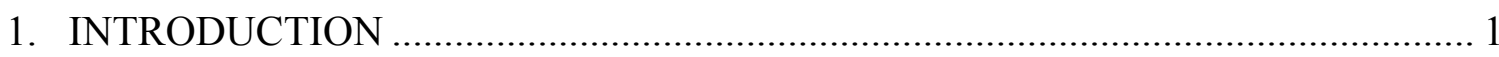

Drinking Water Distribution Systems ................................................................ 1

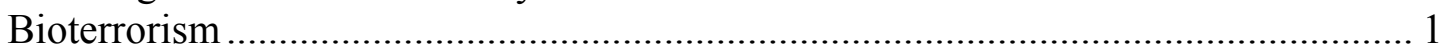

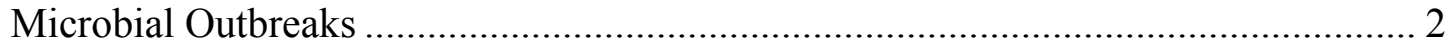

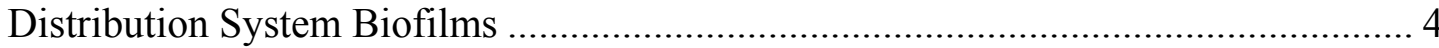

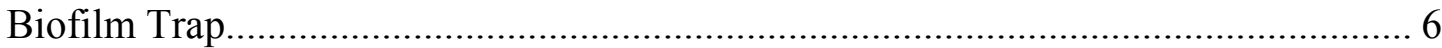

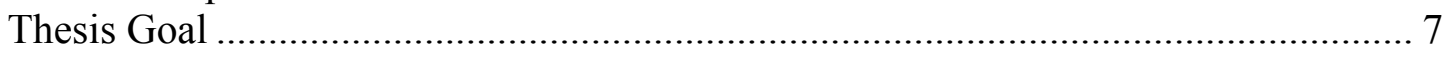

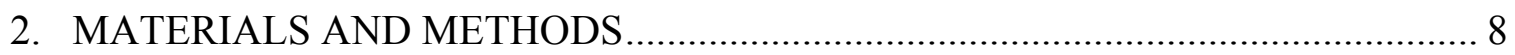

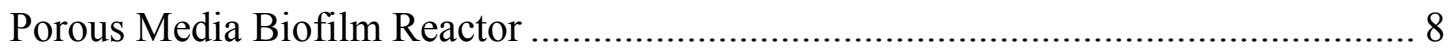

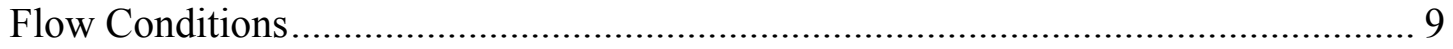

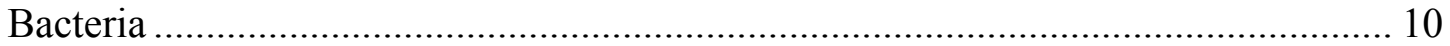

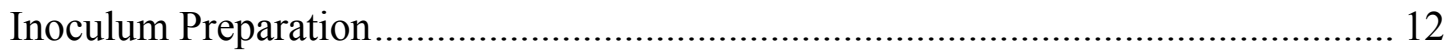

Inoculation and Sampling Procedure …………………….................................... 12

Non-Reactive Tracer Test …………………………….................................... 15

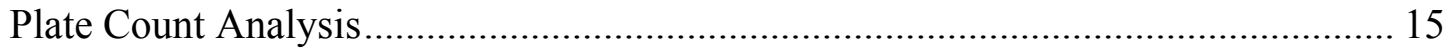

Direct Count Analysis...................................................................................... 15

DNA Extraction and Purification....................................................................... 16

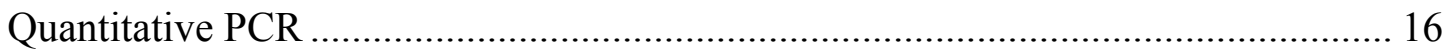

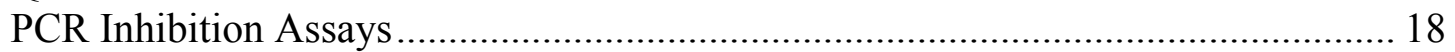

Mass Balance on E. coli O157:H7 ................................................................. 19

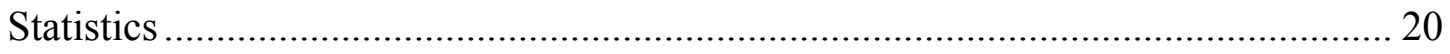

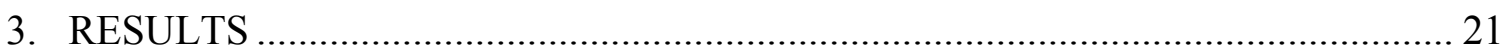

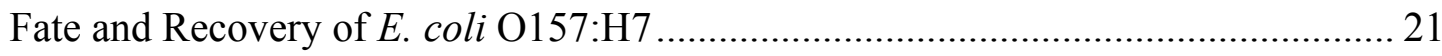

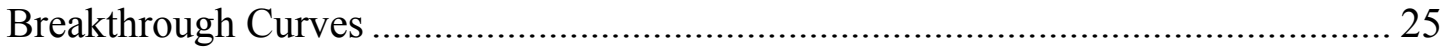

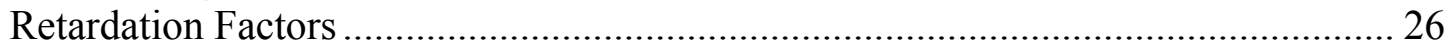

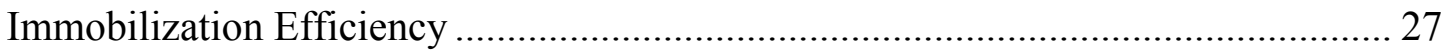

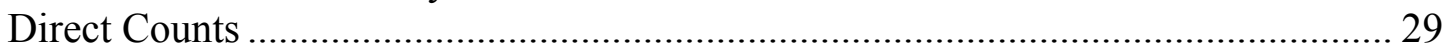

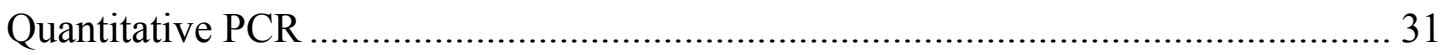

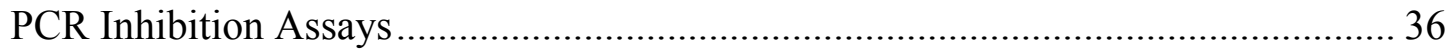

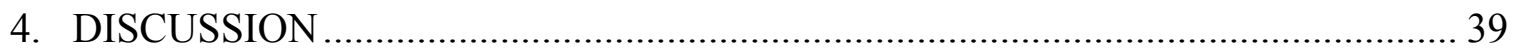

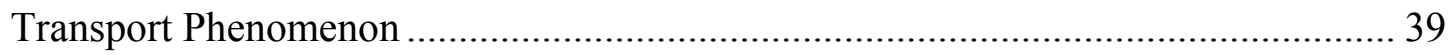

Detection and Quantification of $E$. coli $\mathrm{O} 157: \mathrm{H} 7$.................................................. 42 
TABLE OF CONTENTS - CONTINUED

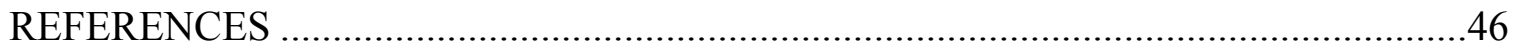

\section{APPENDICES}

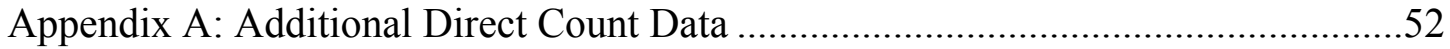

Appendix B. Additional Quantitative PCR Data .....................................................55 


\section{LIST OF TABLES}

Table Page

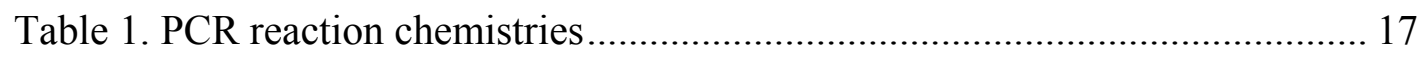

Table 2. Summary of experiments and E. coli O157:H7 enumeration methods ..... 22

Table 3. Percent recoveries for E. coli $\mathrm{O} 157: \mathrm{H} 7$............................................. 22

Table 4. Average hydraulic residence times, mean cell residence times and

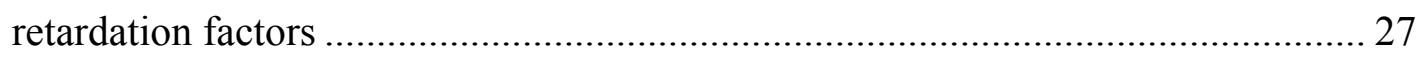




\section{LIST OF FIGURES}

Figure

Page

1. Microbial outbreak frequencies

2. Cross-sectioned water distribution pipe showing biofilm colonization.

3. Scanning electron micrograph showing bacteria on pipe surface.

4. Packed porous media biofilm reactor (A), and close-up of the reactor base (B)...8

5. Flow schematic for biofilm experiments . .9

6. Maps of delivery and helper plasmids .11

7. Harvesting biofilm from stir bar .... .14

8. Total number of $E$. coli $\mathrm{O} 157: \mathrm{H} 7$ within reactors .23

9. Total number of $E$. coli $\mathrm{O} 157: \mathrm{H} 7$ in effluent samples. .24

10. Breakthrough curves .25

11. E. coli $\mathrm{O} 157: \mathrm{H} 7$ in inocula, and the average immobilized fraction of inocula ..28

12. Plate counts compared with direct counts for control experiment $\# 5$. .29

13. Plate counts compared with direct counts for thin biofilm experiment \#5 _........30

14. Plate counts compared with direct counts for thick biofilm experiment \#2 .......30

15. Plate counts vs. qPCR for effluent samples from control experiment \#5 ..........31

16. Plate counts vs. qPCR for control experiment \#5 .32

17. Plate counts vs. qPCR for effluent samples from thin biofilm experiment \#5 ...32

18. Plate counts vs. qPCR for thin biofilm experiment \#5 .33

19. Plate counts vs. qPCR for effluent samples from thick biofilm experiment \#2 .33

20. Plate counts compared with qPCR for thick biofilm experiment \#2 .34 


\section{LIST OF FIGURES - CONTINUED}

Figure

Page

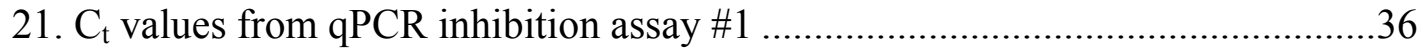

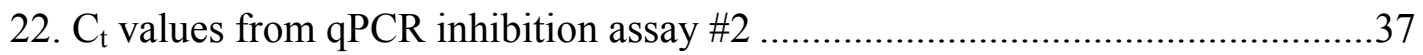




\begin{abstract}
The inadvertent or deliberate introduction of bacterial pathogens into drinking water systems can lead to serious public health consequences. As a result, rapid sampling opportunities within distribution systems are needed that can provide information on the source, species and fate of introduced pathogens. In this study, a porous media biofilm reactor was used to investigate the ability of an established mixed-species drinking water biofilm to immobilize cyan-labeled Escherichia coli $0157: \mathrm{H} 7$ as a model pathogen. Test reactors were colonized with biofilm for two or three weeks at $0.5 \mathrm{mg} / \mathrm{l} \mathrm{C}$, resulting in the formation of thin and thick biofilms, respectively. Colonized reactors were then injected with slug doses of approximately 1 x $10^{9} \mathrm{cfu} E$. coli O157:H7. Plate counts were able to successfully close a mass balance on $E$. coli $\mathrm{O} 157: \mathrm{H} 7$ around the reactor and were used measure the fractions of inocula immobilized within reactors. Compared with control reactors $(0.22 \%)$, reactors colonized for two or three weeks immobilized significantly more cells $(0.75 \%$ and $9.37 \%$ respectively). For E. coli $\mathrm{O} 157: \mathrm{H} 7$ passing through the reactor, retardation with respect to the bulk fluid was measured. Retardation factors $\left(\mathrm{R}_{\mathrm{f}}\right)$ indicated that cells traveling through colonized reactors were significantly retarded compared to those traveling through clean control reactors, resulting in a prolonged washout of cells. Quantitative PCR (qPCR) and direct microscopic counts were also used to enumerate $E$. coli $\mathrm{O} 157: \mathrm{H} 7$ cells. Threshold cycle $\left(\mathrm{C}_{\mathrm{T}}\right)$ values from qPCR typically underestimated the plate counts for effluent samples and were highly inconsistent with respect to enumerating cells entrained in biofilm or attached to reactor surfaces. Possible inhibition by biofilm-associated substances was investigated. Direct microscopic counts were not possible when homogenized biofilm was present and otherwise consistently overestimated plate counts by an average of 0.6 orders of magnitude. This data shows that engineered porous media systems colonized with biofilm may be an effective tool for immobilizing pathogens from bulk flow in drinking water distribution systems.
\end{abstract}




\section{INTRODUCTION}

\section{Drinking Water Distribution Systems}

Drinking water distribution systems are fundamental components of centralized water systems (CWS) that deliver finished water from treatment facilities to consumers. In the United States there are almost one million miles of water distribution pipe with 13,200 miles of new pipe installed each year, as well as an estimated 154,000 finished water storage facilities (NRC, 2006). These dispersed systems make up a majority of the physical infrastructure of water utilities. Moreover, the multitude of accesses to these systems makes them vulnerable to contamination by pathogenic microbes (GAO, 2004). Contamination risks may be linked to unintentional microbial outbreaks as well as the potential for intentional contamination, as in a bioterrorist attack.

\section{$\underline{\text { Bioterrorism }}$}

Functional early-warning systems for water distribution system monitoring necessitate real-time methods for detecting contaminants. While real-time pathogen monitoring systems have been investigated (Gilbride et al, 2006; Siragusa et al, 1999), no reliable methods currently exist for the real-time detection of pathogens in drinking water systems (Lim et al, 2005). As a result, minimizing the turn-around time between discovery and response is critical in preventing exposures. For bioterrorist attacks involving human pathogens, practical steps to reducing this turn-around time include: rapidly locating the source, determining the species and associated pathogenicity of the 
responsible microbes, and accurately predicting the fate of introduced cells. While bioterrorism targeting drinking water systems is a novel risk to public health, unintentional microbial outbreaks have been a persistent and significant challenge for drinking water utility managers.

\section{$\underline{\text { Microbial Outbreaks }}$}

Microbial outbreaks occur when human pathogens enter distribution systems and cause illness in consumers. Such outbreaks have been linked to water treatment failures and problems with distribution system integrity. In an effort to protect public health, the Safe Drinking Water Act (SDWA), published in 1974, describes rules and regulations that require drinking water utilities to meet specific standards for water quality.

As part of the SDWA, the Total Coliform Rule (TCR), published in 1989, represents a regulatory effort to prevent microbial outbreaks by requiring that all public water systems monitor their distribution systems for total coliform bacteria. Traditionally, total coliforms are used as indicators of biological contamination because they are abundant in the feces of warm-blooded animals and they are relatively easy to detect compared with pathogenic microbes. Opinions have varied on whether monitoring for total coliforms is sufficient for detecting and preventing microbial outbreaks (Harwood et al, 2005). However, since the TCR was enacted, the number of outbreaks in CWS has, for the most part, decreased (Figure 1) (NRC, 2006). Over that same period however, the percentage of outbreaks which were attributable to problems within the distribution 


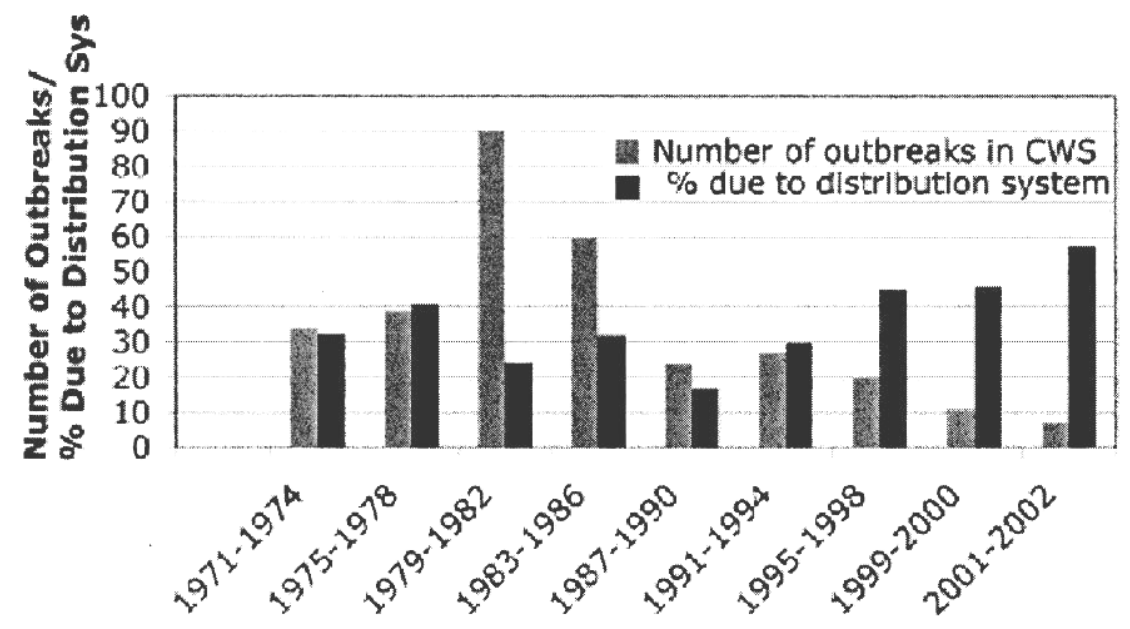

Figure 1: Microbial outbreak frequencies in centralized water systems (CWS) by year, along with the percent attributable to the distribution system (NRC, 2006)

system has steadily increased. This percentage peaked between 2001 and 2002 at nearly $60 \%$.

In 2003, the EPA began a mandated, six-year review of the Total Coliform Rule (TCR), as required by the SDWA. Expert testimony at this review included numerous presentations focused on better integration between distribution system issues and the existing TCR (www.epa.gov/safewater/disinfection/tcr/regulation_revisions.html). The proposed revisions seek to create a more holistic approach to monitoring and preventing future microbial outbreaks. One issue associated with distribution system water quality that was discussed, was the growth and release of biofilm. 


\section{$\underline{\text { Distribution System Biofilms }}$}

Biofilms in drinking water distribution systems are heterogeneous, multi-species microbial communities that colonize the surfaces of pipes (LeChevallier, 1987) (Figure 2). Besides microorganisms, distribution system biofilms are typically characterized by

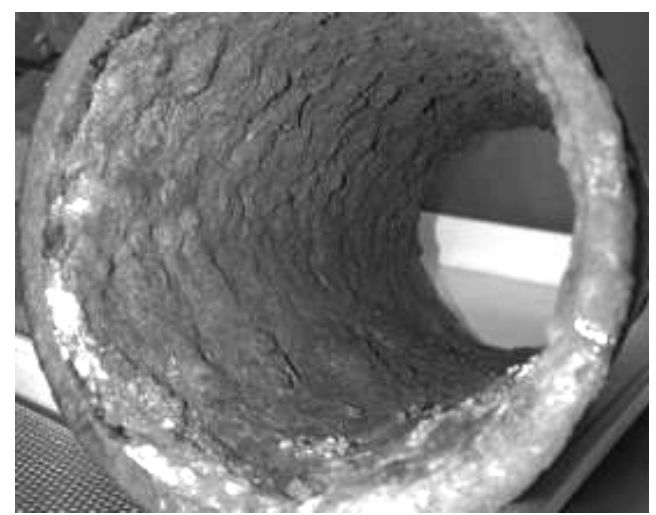

Figure 2: Cross-sectioned water distribution pipe showing colonized biofilm (Davey, 2005)

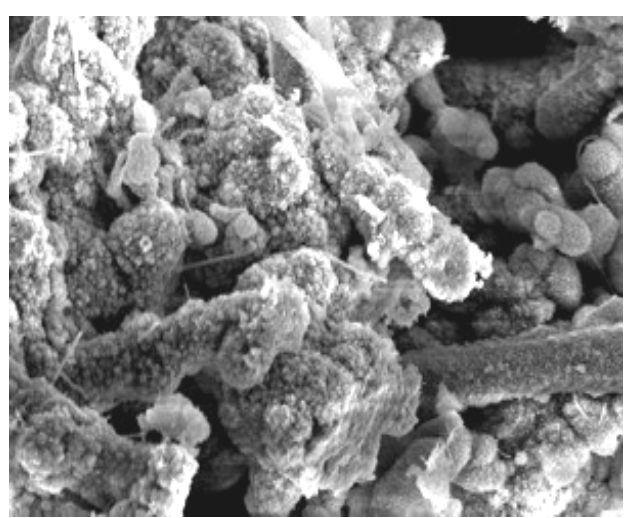

Figure 3: Scanning electron micrograph showing bacteria on pipe surface (Davey, 2005)

extracellular polymers, entrained inorganic and organic materials, and byproducts of microbial influenced corrosion (MIC) (Beech, 2004). In distribution systems that are fed effectively treated water and do not have infiltration issues associated with pipeline fractures, biofilms are suspected to be the primary source of microorganisms (LeChevallier et al, 1987). Biofilms form in a drinking water distribution systems when planktonic cells attach to surfaces and proliferate (Figure 3). As a result, biofilmassociated microbes are typically ubiquitous in the environment and pose little threat to public health. 
However, established biofilms may significantly influence the fate of pathogenic microbes introduced to the bulk flow. Coliforms (Camper et al, 1991; McMath et al, 1999), Legionella (Längmark et al, 2005; Liu et al, 2006; Rogers et al, 1984), Cryptospridium oocysts (Searcy et al, 2006) Helicobacter pylori (Mackay et al, 1998) Escherichia coli (Banning et al, 2003; Camper et al, 1996; Li et al, 2006), Pseudomonas aeruginosa (Banning et al, 2003) and Mycobacterium (September et al, 2004) have all been studied vis-à-vis distribution system biofilms. Interactions between microbes and biofilms are dependent on at least two important factors: the surfaces properties of microbes and the physical structure of biofilm. When microbes are present in aqueous environments their surface charges are neutralized by ions in solution which form a diffuse electric double layer known as the Gouy-Chapman layer (Ellwood et al, 1982).The thickness of this layer, which is dependent on the ionic strength of the solution, influences the attractive forces between microbes and surfaces (Stevik et al, 2003). Using laboratory-scale experiments, researchers have shown that the ionic strength of a solution can impact the adsorption and retention of microbes (Abbott et al, 1983; Jewett et al, 1995). Surface properties of microbes are also dynamic, and changes may be microbially-induced, which can affect the reversibility of attachment (Sharma et al, 1985).

Biofilm structure has been characterized as a complex, 3-dimensional assembly of 'mushroom' shaped towers and strings (Costerton, 1995), and as a porous framework of intertwined filamentous biomass (Okabe et al, 1998). The immobilization of microbes within this matrix is influenced by both physical and chemical properties. The physical 
structure of biofilms can contribute to immobilization by reducing the shear force on cells and by increasing the number of adsorption sites. The structure of biofilm is further complicated by the presence of extracellular polymers. Because polymers are often polysaccharides, they can contribute to the irreversible adhesion of bacteria through hydrogen bonding and dipole-dipole interactions (Costerton, 1984; Fletcher \& Floodgate, 1973). Once trapped in biofilms, pathogens can also be protected from disinfectants and antimicrobials through mass transfer resistance (Stewart et al, 1996) or the formation of persister cells (Roberts \& Stewart, 2005). These relationships could complicate efforts to monitor and detect pathogens in distribution systems as well as prolong contamination by gradually, and unpredictably, releasing pathogens as part of detached biofilm.

Consequently, interactions between biofilms and pathogens have traditionally been viewed as a factor of distribution system water quality that contributes to public health risks.

\section{$\underline{\text { Biofilm Trap }}$}

In 2003, the Army Research Office (ARO) awarded Montana State University a grant aimed at exploring the interactions between microbial pathogens and biofilms in drinking water distribution systems. One component of this exploration was the idea of using pathogen-biofilm interactions as a tool for monitoring and sampling distribution systems. In other words, if biofilms growing on the surfaces of pipes can trap and harbor pathogens from the bulk flow, can an engineered system increase the efficiency of this interaction enough to qualify as a monitoring device? A 'biofilm trap' would not be 
intended to treat microbial outbreaks, but could possibly provide rapid sampling opportunities at critical points within a distribution network. This could reduce the time required to locate a source, characterize the risk, and predict the fate of pathogens in drinking water distribution systems.

\section{Thesis Goal}

This thesis addresses one aspect of the larger biofilm trap project by attempting to isolate and characterize the capacity of a porous media biofilm, grown under drinking water conditions, to immobilize a model pathogen. Biofilms were grown under continuous flow for two and three weeks by feeding porous media reactors a mixture of defined nutrients and dilution water from a biologically activated carbon system (BAC). The latter source was fed by City of Bozeman tap water and produced dechlorinated dilution water as well as a consistent source of indigenous drinking water microorganisms. These microorganisms served as an inoculum for establishing a biofilm on the reactor media and surfaces.

Escherichia coli (E. coli) 0157:H7 was used to model the behavior of waterborne

pathogens. Colonized reactors were injected with a slug dose of approximately $1 \times 10^{9} \mathrm{E}$. coli $\mathrm{O} 157: \mathrm{H7}$. The transport of these cells through the porous media biofilm was described using plate counts, direct microscopic counts, and quantitative PCR (qPCR). Three experiment conditions were tested 1) control - clean and sterile 2) 'thin' biofilm two weeks of biofilm colonization, and 3) 'thick' biofilm - three weeks of biofilm colonization. 


\section{MATERIALS AND METHODS}

\section{$\underline{\text { Porous Media Biofilm Reactor }}$}

A porous media biofilm reactor was constructed by filling a cylindrical polycarbonate container with glass beads (Figure 4A). The reactor dimensions were $6 \mathrm{~cm}$
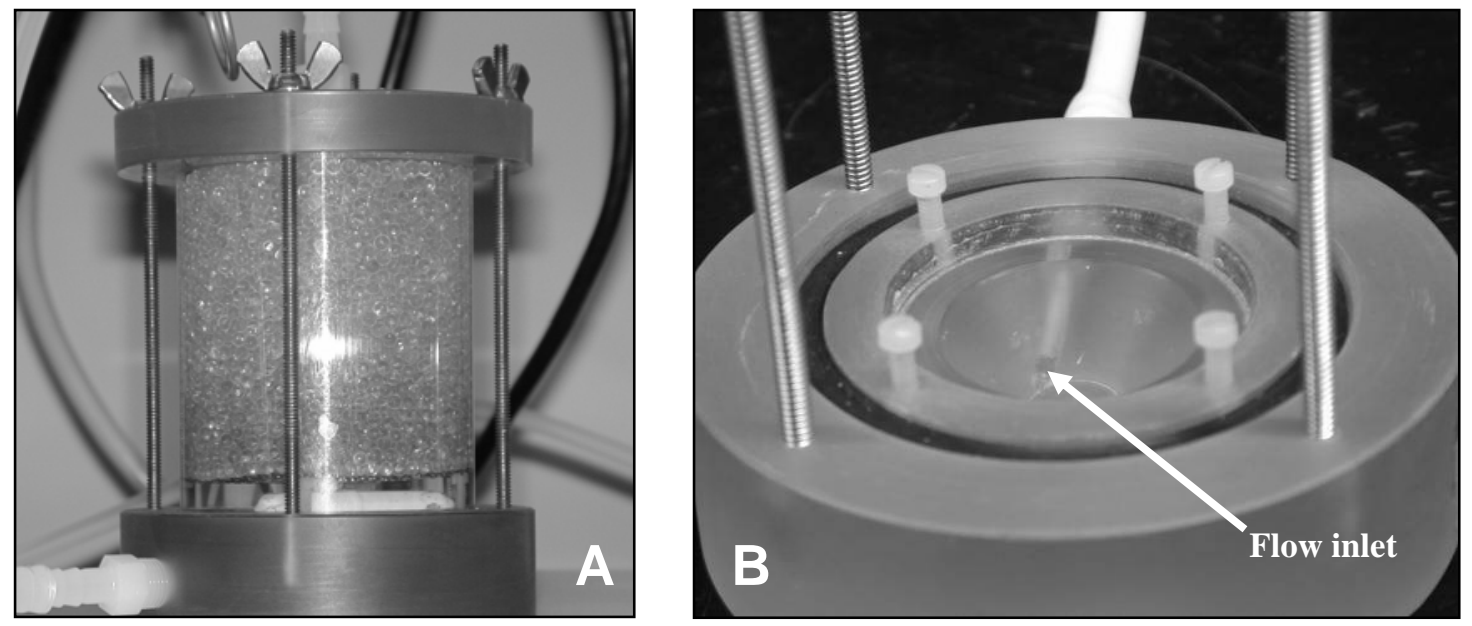

Figure 4. Packed porous media biofilm reactor (A), and close-up of the reactor base (B)

in diameter and $6 \mathrm{~cm}$ in height. A peristaltic pump was used to meter continuous flow through the reactor. Flow entered through the base, directed tangential to a conical recess in the reactor bottom (Figure 4B). A stir bar spun at $200 \mathrm{rpm}$ in an opposite direction to the flow to ensure the system was well-mixed. A fine stainless steel screen separated the stir bar from the reactor media. Reactors were packed with $220 \mathrm{~g}$ of $3 \mathrm{~mm}$ borosilicate (Chemglass Vineland, NJ, USA, CAT \# CG-1101-02) beads for each experiment. 


\section{Flow Conditions}

Reactors for biofilm experiments were colonized under the following flow conditions: Reactors were fed at $24.75 \mathrm{ml} / \mathrm{min}$ from the BAC system with a supplement of $50 \mathrm{mg} / \mathrm{l}$ organic carbon at $0.25 \mathrm{ml} / \mathrm{min}$ for a total flow of $25 \mathrm{ml} / \mathrm{min}$ and a total organic

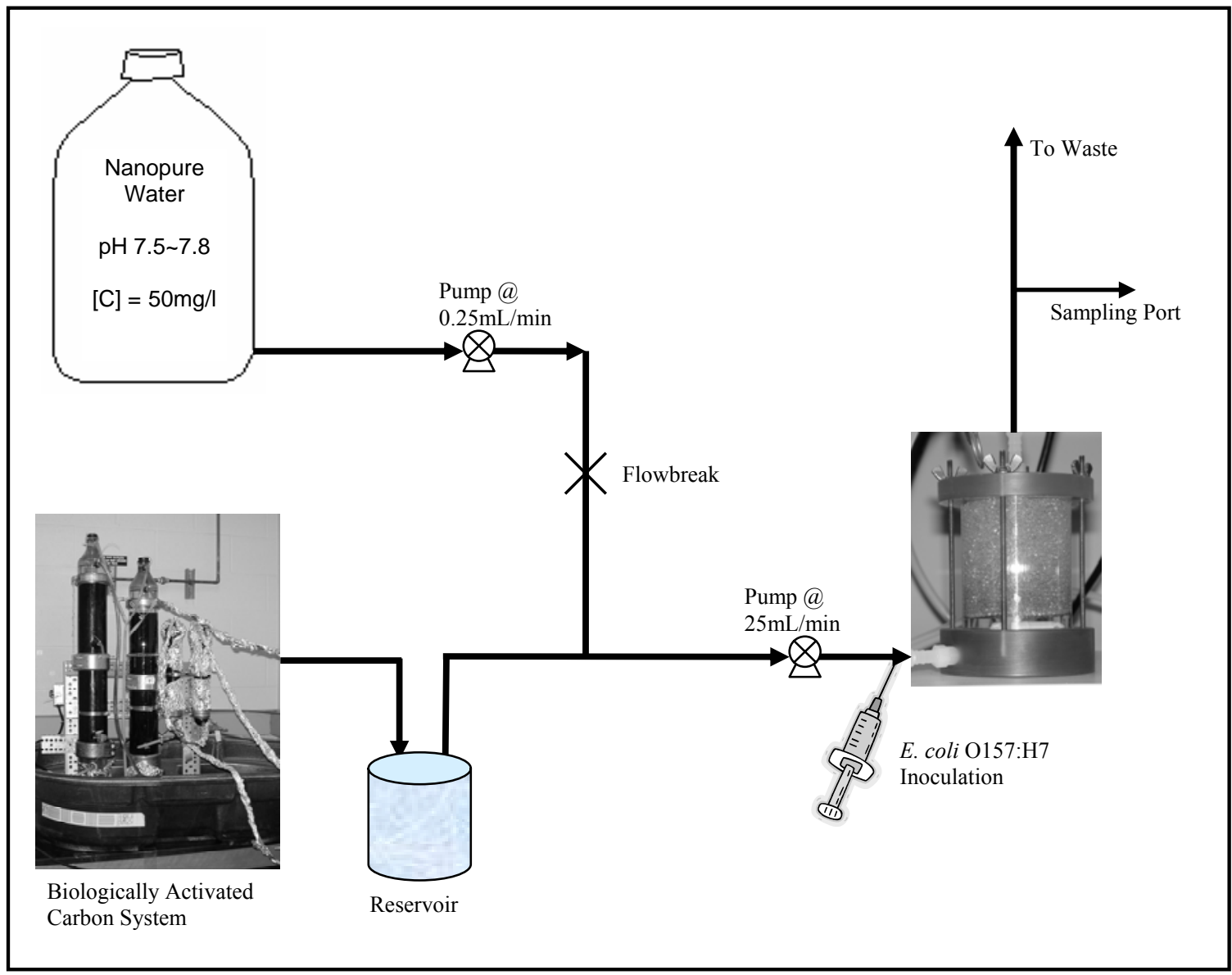

Figure 5. Flow schematic for biofilm experiments

carbon concentration of $0.5 \mathrm{mg} / 1$ (Figure 5). The organic carbon supplement stock solution was a combination of amino acids and carbohydrates with the following concentrations: $4.7 \mathrm{~g} / \mathrm{L}$ glutamic acid, $5.3 \mathrm{~g} / \mathrm{L}$ aspartic acid, $5.5 \mathrm{~g} / \mathrm{L}$ serine, $4.7 \mathrm{~g} / \mathrm{L}$ 
alanine, $4.8 \mathrm{~g} / \mathrm{L}$ glucose, $4.8 \mathrm{~g} / \mathrm{L}$ galactose, $4.8 \mathrm{~g} / \mathrm{L}$ arabinose. This recipe was used to make a concentrated stock solution with around $13,000 \mathrm{mg} / \mathrm{l}$ carbon which was diluted in sterile nanopure water to $50 \mathrm{mg} / \mathrm{l}$. Before diluting, the exact concentration of the stock solution was measured using a Dohrmann DC80 organic carbon analyzer and the $\mathrm{pH}$ was adjusted to 7.5-7.8 with $6 \mathrm{~N}$ sodium hydroxide. Nitrogen $(0.1 \mathrm{mg} / 1)$, provided by amino acids in the carbon supplement, and phosphorous $(0.12 \mathrm{mg} / \mathrm{l})$, from the BAC treated tap water, were sufficiently available to ensure that carbon was a limiting nutrient.

\section{$\underline{\text { Bacteria }}$}

E. coli $\mathrm{O} 157: \mathrm{H} 7$ (strain 932), a human isolate (obtained from Dept. of Microbiology, Montana State University), was used as a model pathogen. To make plate counting and microscopic enumeration of the target organism possible in the presence of a biofilm matrix, the strain was transformed. Genes encoding for a fluorescent protein and conveying antibiotic resistances were chromosomally integrated. The aforementioned

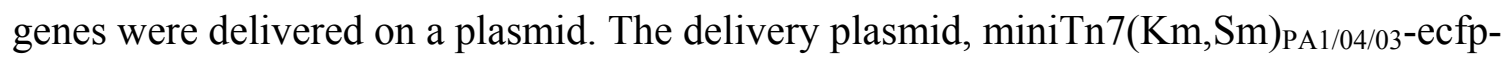
a, and a helper plasmid, pUX-BF13 (Figure 6) were isolated from E. coli carrier strains using a QIAprep Spin Miniprep Kit (Qiagen, Valencia, CA, USA). The delivery plasmid contained genes responsible for antibiotic resistance to kanamycin, streptomycin and chloramphenicol, as well as the gene encoding for the cyan fluorescent protein (CFP). The helper plasmid ensured that the genes inserted into the desired location and orientation within the genome. Electroporation was done in an Electroporator 2510 


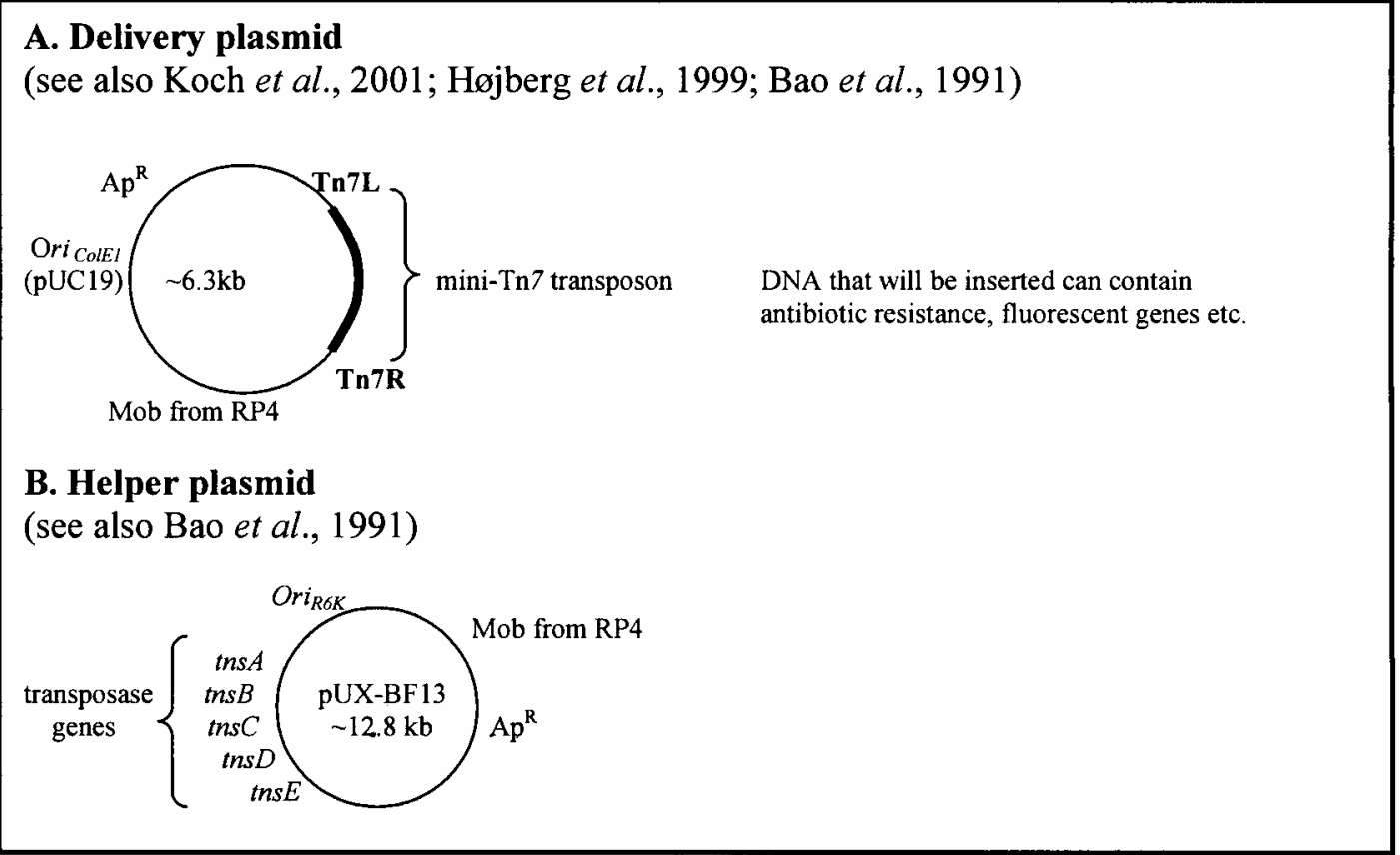

Figure 6. Maps of delivery and helper plasmids

(Eppendorf, Westbury, NY, USA) for $5 \mathrm{~ms}$ at $2400 \mathrm{~V}$, as recommended by the manufacturer.

Electrocompetent cells were prepared based on a protocol from the University of Washington (http://depts.washington.edu/bakerpg/electrocompetent.html) as follows: Two single colonies of $E$. coli $\mathrm{O} 157: \mathrm{H} 7$ were each transferred into 11 media bottles containing $500 \mathrm{ml}$ Luria Bertani (LB) broth (Fisher Scientific, Cat\# BP1426-500). The cultures were grown overnight in a shaking incubator at $37^{\circ} \mathrm{C}$ and $180 \mathrm{rpm}$ to an optical density of $0.5-0.8$ measured at $600 \mathrm{~nm}$. The flasks were transferred to an ice bath for 30 min before chilled cultures were harvested by centrifugation $\left(4^{\circ} \mathrm{C}, 4000 \mathrm{xg}\right.$ for $15 \mathrm{~min}$ in GSA rotor bottles). The harvesting and resuspension steps were repeated four times with decreasing suspension volumes according to the following (solutions were sterile and 
chilled to $4^{\circ} \mathrm{C}$ ): 1) $1 \mathrm{~L}$ water, 2) $0.5 \mathrm{~L}$ water, 3) $20 \mathrm{ml} 10 \%$ glycerol, 4) $2.5 \mathrm{ml} 10 \%$ glycerol. Aliquots of this final cell suspension were immediately frozen and stored at $70^{\circ} \mathrm{C}$.

\section{Inoculum Preparation}

Full strength LB broth supplemented with $6 \mathrm{mg} / \mathrm{l}$ chloramphenicol $(\mathrm{Cm})$ was used to grow $10 \mathrm{ml}$ cultures of transformed E. coli $\mathrm{O} 157: \mathrm{H} 7$ in $50 \mathrm{ml}$ culture tubes. After 16 hours at $37^{\circ} \mathrm{C}$ and $180 \mathrm{rpm}$, stationary phase cells were harvested by centrifugation for $5 \mathrm{~min}$ at $5000 \mathrm{x}$ g. Cell pellets were resuspended in $10 \mathrm{ml}$ filtersterilized BAC effluent. This wash step was repeated once. The final cell suspension was shaken at room temperature at $150 \mathrm{rpm}$ for 24 hours before being introduced to reactors. The purpose of this procedure was to allow possible changes in physiology or size that may be caused by low nutrient concentrations. (Bjergbaek \& Roslev, 2005). Cell

concentrations ranged from $4.87 \times 10^{8}$ to $1.82 \times 10^{9} \mathrm{cfu} / \mathrm{ml}$ according to plate counts and $3.92 \times 10^{9}$ to $1.05 \times 10^{10}$ cells $/ \mathrm{ml}$ as determined by direct counts.

\section{$\underline{\text { Inoculation and Sampling Procedure }}$}

The sampling procedure was performed in the same manner for non-biofilm control experiments and biofilm experiments. For biofilm experiments, a mixed-species biofilm, with organisms originating from the BAC treated tap water, was grown for either two or three weeks at $0.5 \mathrm{mg} / \mathrm{l} \mathrm{C}$. Following biofilm formation, colonized reactors were inoculated with $1 \mathrm{ml}$ of $E$. coli $\mathrm{O} 157: \mathrm{H} 7$ (prepared as described earlier). A fine gauge 
needle was used to pierce the tubing immediately upstream from where flow entered the reactor and introduce $E$. coli $\mathrm{O} 157: \mathrm{H} 7$ cells to the bulk flow. Simultaneously to inoculation, the reactor effluent was diverted to sterile flasks. Effluent samples were collected on $82 \mathrm{~s}$ intervals for $820 \mathrm{~s}$, yielding ten samples of approximately $34 \mathrm{ml}$. The number of pore volumes collected in $820 \mathrm{~s}$ varied for each experiment because free pore spaces were reduced by biofilm accumulation. Samples were placed on ice immediately following collection.

Once all effluent samples were collected, flow to the reactor was stopped and the reactor was relocated from its stir plate to a laminar flow hood for destructive sampling. The pore fluid remaining in the reactor was drained into a sterile graduated cylinder in order to measure its volume. Biofilm volumes were calculated by subtracting the freelyflowing pore fluid drained from the reactor from the measured clean reactor pore space. Any difference in volume was assumed to be attributable to biofilm accumulation. In experiments where biofilm was present, the pore fluid was homogenized for $30 \mathrm{~s}$ (Bio homogenizer M133/1281, Biospec Products, Bartlesville, OK, USA) on ice (to prevent heating the sample). Approximately $35 \mathrm{ml}$ of this pore fluid sample were transferred to a sterile flask and placed in an ice bath.

The reactor was disassembled and the glass beads were transferred to a sterile wide-mouth $250 \mathrm{ml}$ flask using a sterile spatula and funnel. $50 \mathrm{ml}$ of filter-sterilized BAC effluent was added to the flask. To assist in washing any E. coli $\mathrm{O} 157: \mathrm{H} 7$ or biofilm from the beads this solution was vortexed ( $30 \mathrm{~s})$ and sonicated ( $30 \mathrm{~s}$, model fs15, Fisher Scientific). This elution procedure was repeated once before transferring the volume 
through a fine-mesh steel screen into a second sterile flask. For a final rinse, an additional $50 \mathrm{ml}$ of rinse water was added into the first flask followed by vortexing ( $2 \mathrm{~min}$ ). This second rinse was passed through the screen and combined with the volume in the second flask for maximization of $E$. coli $\mathrm{O} 157: \mathrm{H} 7$ recovery. The combined volume was $100 \mathrm{ml}$ plus the volume of accumulated biofilm. When biofilm was present, the sample was homogenized for $30 \mathrm{~s}$ and approximately $35 \mathrm{ml}$ were transferred to a $50 \mathrm{ml}$ tube and placed in an ice bath. To recover biological material associated with the internal reactor surfaces, filter-sterilized BAC effluent was used to rinse the surfaces with the following

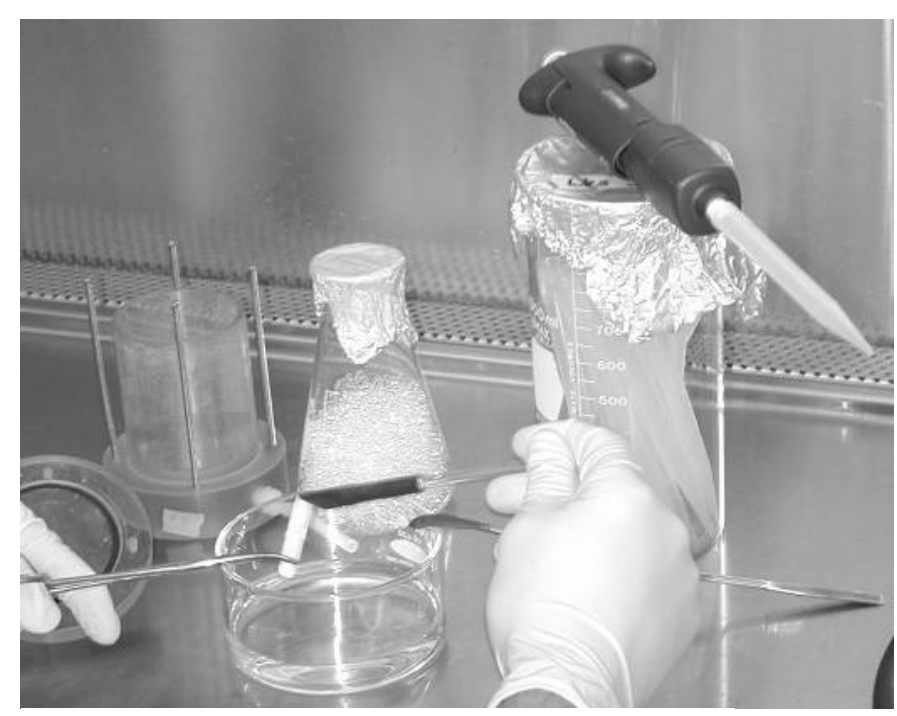

Figure 7. Harvesting biofilm from stirbar

volumes for the respective surfaces: $15 \mathrm{ml}$ top, $30 \mathrm{ml}$ sides, $20 \mathrm{ml}$ screen, $10 \mathrm{ml}$ stir bar, and $25 \mathrm{ml}$ bottom. Surfaces were initially rewet with 5-10 $\mathrm{ml}$ and then scraped with a rubber policeman (Figure 7), followed by a second rinse with the remaining volume. Ideally, any biological material associated with the surfaces was rinsed into a sterile glass container for optimization of E. coli $\mathrm{O} 157: \mathrm{H} 7$ recovery. Harvested material was 
homogenized for $30 \mathrm{~s}$ before transferring approximately $35 \mathrm{ml}$ to a $50 \mathrm{ml}$ tube and storing in an ice bath until further processing.

\section{$\underline{\text { Non-Reactive Tracer Test }}$}

Hydrodynamics of a clean and sterile reactor were described using fluorescein dye as a tracer for breakthrough curves (Sharp, 1999). Under the same flow conditions as described above for clean control reactors, $1 \mathrm{ml}$ of $100 \mathrm{ppm}$ fluorescein dye (Sigma F6377, St. Louis, MO, USA) was injected into a porous media reactor. Effluent was collected on $82 \mathrm{~s}$ intervals for $820 \mathrm{~s}$ and each sample was analyzed using a spectrophotometer at $490 \mathrm{~nm}$.

\section{$\underline{\text { Plate Count Analysis }}$}

E. coli $\mathrm{O} 157: \mathrm{H} 7$ were enumerated by spread plating in triplicate. Samples were serially diluted in filter-sterilized BAC effluent such that $100 \mu 1$ spread on an agar plate produced 30-300 colonies. All samples were plated on LB agar (Fisher Scientific, Cat\#

BP1425-2) supplemented with $6 \mathrm{mg} / \mathrm{l} \mathrm{Cm}$ and incubated at room temperature for 3 days. Colony forming units (cfu) were counted following incubation.

\section{Direct Count Analysis}

Selected samples were serially diluted in filter-sterilized BAC effluent. After vortexing for $30 \mathrm{~s}, 1 \mathrm{ml}$ was filtered through a $0.44 \mu \mathrm{m}$ black polycarbonate filter membrane (GE Water and Process Technologies, Watertown, MA, USA). Dilutions 
having between 20-200 cells per field of view were used for enumeration. Filters were mounted with oil on microscope slides. Twenty fields of view were captured using a black and white camera mounted to a Nikon E800 microscope with a 100 x 1.4 NA oil objective and CFP fluorescence filters (excitation 426-446 nm, dichromic mirror $455 \mathrm{~nm}$, and emission 460-500 nm). MetaVue, Version 6.1, (Universal Imaging, Downington, PA, USA) was used for capturing images and MetaMorph, Version 6.1r, was used to count $E$. coli $\mathrm{O} 157: \mathrm{H} 7$ cells.

\section{DNA Extraction and Purification}

Genomic DNA was extracted and purified using the Power Soil TM DNA Isolation Kit (Mo Bio Laboratories, Carlsbad, CA, USA). The manufacturer's 'Experienced User Protocol" was followed with the following exceptions: 1) $200 \mu$ l of homogenously suspended cells were added to the lysis matrix as opposed to soil, 2) cell lysis was achieved by bead beating in a FastPrep machine (MP Biomedicals, Aurora, OH, USA) for $30 \mathrm{~s}$ at a speed setting of $5.0 \mathrm{~m} / \mathrm{s}$, and 3) only $1350 \mu 1$ were loaded on to the spin filter.

\section{Quantitative PCR}

E. coli O157:H7 DNA was detected by quantitative PCR (qPCR) using a SmartCycler II (Cepheid, Sunnyvale, CA, USA). Multiple protocols and reagents were used in an effort to improve repeatability and optimize efficiency. In all PCR assays $2 \mu 1$ of extracted genomic DNA was added to $23 \mu \mathrm{l}$ of PCR mixture containing $0.3 \mu \mathrm{M}$ of 
primer stx 1 - forward (5' - GACTGCAAAGACGTATGTAGATTCG - 3') (Sharma \& Dean-Nystrom, 2003) and $0.3 \mu \mathrm{M}$ of primer stx 1 - reverse $\left(5^{\prime}-\right.$

ATCTATCCCTCTGACAACTGC - 3') (Sharma \& Dean-Nystrom, 2003). stx1 encodes for shiga toxin 1 and has been shown to successfully distinguish $E$. coli O157:H7 within complex biological matrices (Sharma \& Dean-Nystrom). qPCR assays were either based on SYBR ${ }^{\circledR}$ Green or on Taqman ${ }^{\mathrm{TM}}$ chemistry. Two commercially available PCR master mixes were used for SYBR ${ }^{\circledR}$ Green based assays $-\mathrm{SYBR}^{\circledR}$ Green PCR Master Mix and Power SYBR ${ }^{\circledR}$ Green PCR Master Mix (both Applied Biosystems, Foster City, CA, USA). Both were used according to the manufacturer's protocol. In the case of Taqman ${ }^{\text {TM }}$ assays an stx1-probe was used in conjunction with 1 x AmpliTaq GOLD Master Mix (Applied Biosystems, Foster City, CA, USA) and had a 6-FAM fluorescent label attached to the 5'-end of the stx 1 -probe and a BHQ1 quencher attached to the 3'-end. The PCR reaction chemistries used in each experiment are summarized in Table 1 below.

\begin{tabular}{|c|c|c|c|}
\hline Reactor Condition & qPCR Reaction Chemistry & Reactor Condition & qPCR Reaction Chemistry \\
\hline Control 1 & SYBR $^{\circledR}$ Green & Thin 3 & Power SYBR ${ }^{\circledR}$ Green \\
\hline Control 3 & Taqman $^{\mathrm{TM}}$ & Thin 4 & Power SYBR $^{\circledR}$ Green \\
\hline Control 5 & Taqman $^{\mathrm{TM}}$ & Thin 5 & Power SYBR $^{\circledR}$ Green \\
\hline Control 7 & Power SYBR $^{\circledR}$ Green & Thick 1 & SYBR $^{\circledR}$ Green \\
\hline Thin 1 & SYBR $^{\circledR}$ Green & Thick 2 & SYBR $^{\circledR}$ Green \\
\hline
\end{tabular}

Table 1. PCR reaction chemistries

Cycling parameters for Taqman assays were: $570 \mathrm{~s}$ at $95^{\circ} \mathrm{C}$ followed by 45 cycles of $20 \mathrm{~s}$ at $95^{\circ} \mathrm{C}, 30 \mathrm{~s}$ at $57^{\circ} \mathrm{C}$, and $25 \mathrm{~s}$ at $72^{\circ} \mathrm{C}$. For $\mathrm{SYBR}^{\circledR}$ Green based assays the cycle parameters were: $8 \mathrm{~min}$ at $95^{\circ} \mathrm{C}$ followed by 50 cycles of $20 \mathrm{~s}$ at $95^{\circ} \mathrm{C}, 25 \mathrm{~s}$ at $55^{\circ} \mathrm{C}$ and 
$25 \mathrm{~s}$ at $72^{\circ} \mathrm{C}$. For assays using $\mathrm{SYBR}^{\circledR}$ Green, melt curve analyses were performed following PCR cycling by heating PCR products from $65^{\circ} \mathrm{C}$ to $95^{\circ} \mathrm{C}$ in increments of 0.2

deg/s. Threshold cycles were only considered valid for those reactions which showed the correct melt temperatures. Initially, correct product lengths were verified by loading an aliquot of qPCR product on 2\% agarose gels stained with ethidium bromide.

Threshold cycle values $\left(\mathrm{C}_{\mathrm{t}}\right)$ were determined for all samples by the primary curve method, with background subtraction, using the SmartCycler II software. The $\mathrm{C}_{t}$ values represented the PCR cycle at which fluorescence, as a surrogate measure of target DNA concentration, rose above the user-defined threshold of 30 fluorescent units. Numerical data was exported to a Microsoft ${ }^{\circledR}$ Office Excel spreadsheet for analysis. DNA templates for creating standard curves were obtained in one of two ways: 1) DNA was extracted from a series of cell suspensions generated from serially diluting the inoculum, or 2) genomic DNA extracted from the undiluted inoculum was serially diluted. Standard curves were produced for each experiment and the concentration of E. coli $\mathrm{O} 157: \mathrm{H} 7$ cells in unknown samples were calculated by fitting their $C_{t}$ values to this standard curve.

\section{$\underline{\text { PCR Inhibition Assays }}$}

Two assays were performed to investigate potential qPCR inhibition originating from the presence of biofilm. The biofilm for these assays was grown for two weeks in a porous media biofilm reactor as described earlier. All biofilm from the reactor was recovered and suspended in 100ml of filter-sterilized BAC effluent. The suspended biofilm was then homogenized for $1 \mathrm{~min}$. 
The first assay was performed to investigate if the observed differences in amplification were caused by the co-purification of biofilm-related inhibitory substances. An E. coli O157:H7 culture was grown as described earlier and diluted to the following concentrations of $1 \times 10^{7}, 1 \times 10^{5}, 1 \times 10^{4}$ and $1 \times 10^{2} \mathrm{cfu} / \mathrm{ml}$. Genomic DNA was extracted and purified from the undiluted homogenized biofilm and the four samples of E. coli $\mathrm{O} 157: \mathrm{H} 7$ independently. Mixes of $1 \mu 1$ of E. coli $\mathrm{O} 157: \mathrm{H} 7$ DNA with $1 \mu 1$ of either water or biofilm DNA served as templates for qPCR using Power SYBR ${ }^{\circledR}$ green reaction chemistry and cycling parameters described above.

The second assay investigated if the observed differences in amplification were caused by differences in the DNA extraction and purification efficiency of E. coli O157:H7 DNA in the presence of biofilm. The concentration of homogenized biofilm was varied between samples of $E$. coli $\mathrm{O} 157: \mathrm{H} 7$ (growth conditions described earlier, $\left.\left[\sim 10^{9} \mathrm{cfu} / \mathrm{ml}\right]\right)$. Samples were created by mixing $5 \mathrm{ml}$ of an E. coli $\mathrm{O} 157: \mathrm{H} 7$ culture with $5 \mathrm{ml}$ of homogenized biofilm (approximately $1 \times 10^{7} \mathrm{cfu} / \mathrm{ml}$ ). Four concentrations of biofilm were used - undiluted, 1:10 diluted, 1:100 diluted and 1:10,000 diluted. Genomic DNA was extracted from $200 \mu 1$ aliquots of these four mixtures using the Power Soil TM DNA Isolation Kit as described earlier. This DNA served as a template for qPCR using the same parameters as the first inhibition assay.

\section{Mass Balance on E. coli $\mathrm{O} 157: \mathrm{H} 7$}

A mass balance on E. coli $\mathrm{O} 157: \mathrm{H} 7$ around the reactor was closed using plate count data to compare the total number of cells input to the reactor with the number 
recovered. Recovered cells included all cells in the effluent and pore fluid, in addition to those that were immobilized within the reactor. Immobilized cells were either attached to beads and reactor surfaces for control experiments or entrained in the harvested biofilm attached to those surfaces for test experiments. Cell concentrations from each sample were multiplied by the total final volume in which they were suspended. The mean and standard error of the log differences between input and recovered cells were calculated. A 95\% confidence interval was then determined based on the mean and standard error and 13 degrees of freedom $(n=14)$.

\section{$\underline{\text { Statistics }}$}

To determine if differences in the fraction of inocula immobilized between the three reactor conditions was statistically significant, a two sample, one-sided t-test was used. The null hypothesis for this test was that the geometric means of the percent of cells immobilized was equal for all conditions. The mean and standard error of log differences between $E$. coli $\mathrm{O} 157: \mathrm{H} 7$ cells input and $E$. coli $\mathrm{O} 157: \mathrm{H} 7$ cells immobilized were calculated. Because the number of samples for each condition varied, degrees of freedom were computed using the Welch-Satterwaithe approximation (Ames \& Webster, 1991). The null hypothesis was considered invalid when p-values were less than 0.05 . 


\section{RESULTS}

A porous media biofilm reactor was colonized with an undefined drinking water biofilm. Experiments aimed at testing the ability of the reactor to immobilize a slug dose of the model pathogen, E. coli O157:H7, from bulk flow. Reproducible biofilms were grown for either two or three weeks while controlling three important factors - the flow rate, the organic loading, and the species of the biofilm inoculum (White, 1999). Following two weeks of continuous flow (thin biofilm), a clear gradient of biofilm accumulation was observed which decreased along the direction of flow with no biofilm visible near the effluent port. One additional week (thick biofilm) of growth was sufficient to close this gradient such that biofilm appeared equally along the entire flow path. The average biofilm volumes were $20.8 \pm 1.92 \mathrm{ml}$ ( $23 \%$ of available pore space) for thin biofilms and $52.5 \pm 3.54 \mathrm{ml}$ ( $59 \%$ of available pore space) for thick biofilms.

\section{Fate and Recovery of E. coli $\mathrm{O} 157: \mathrm{H} 7$}

Enumeration of E. coli $\mathrm{O} 157: \mathrm{H} 7$ which passed through reactors and cells which were immobilized within the reactors by plate counting succeeded in closing the mass balance. Data from direct counting and qPCR, while not able to close the mass balance, were compared with plate counts. Table 2 is a summary of experiments showing reactor conditions and the E. coli $\mathrm{O} 157: \mathrm{H} 7$ enumeration methods applied. 


\begin{tabular}{|l|c|c|c|l|c|c|c|}
\hline $\begin{array}{l}\text { Reactor } \\
\text { Condition }\end{array}$ & $\begin{array}{c}\text { Plate } \\
\text { Counts }\end{array}$ & $\begin{array}{c}\text { Total } \\
\text { Direct } \\
\text { Counts }\end{array}$ & $\mathrm{qPCR}$ & $\begin{array}{l}\text { Reactor } \\
\text { Condition }\end{array}$ & $\begin{array}{c}\text { Plate } \\
\text { Counts }\end{array}$ & $\begin{array}{c}\text { Total } \\
\text { Direct } \\
\text { Counts }\end{array}$ & qPCR \\
\hline Control 1 & $\mathrm{X}$ & & $\mathrm{X}$ & Thin 1 & $\mathrm{X}$ & & $\mathrm{X}$ \\
\hline Control 2 & $\mathrm{X}$ & & & Thin 2 & $\mathrm{X}$ & $\mathrm{X}$ & \\
\hline Control 3 & $\mathrm{X}$ & & $\mathrm{X}$ & Thin 3 & $\mathrm{X}$ & & $\mathrm{X}$ \\
\hline Control 4 & $\mathrm{X}$ & & & Thin 4 & $\mathrm{X}$ & & $\mathrm{X}$ \\
\hline Control 5 & $\mathrm{X}$ & $\mathrm{X}$ & $\mathrm{X}$ & Thin 5 & $\mathrm{X}$ & $\mathrm{X}$ & $\mathrm{X}$ \\
\hline Control 6 & $\mathrm{X}$ & $\mathrm{X}$ & & Thick 1 & $\mathrm{X}$ & $\mathrm{X}$ & $\mathrm{X}$ \\
\hline Control 7 & $\mathrm{X}$ & & $\mathrm{X}$ & Thick 2 & $\mathrm{X}$ & $\mathrm{X}$ & $\mathrm{X}$ \\
\hline
\end{tabular}

Table 2. Summary of experiments and E. coli $\mathrm{O} 157: \mathrm{H} 7$ enumeration methods

Quantification of E. coli $\mathrm{O} 157: \mathrm{H} 7$ by plate counting was used to close a mass balance around the reactor. Percent recovery of the inoculum was calculated for each experiment by taking ratios between the total number of cells recovered and the total number of cells in the inoculum (Table 3 ). The $95 \%$ confidence interval for percent recoveries was $94-121 \%$. In other words, $95 \%$ of subsequent experiments would be expected to have a percent recovery between 94 and $121 \%$.

\begin{tabular}{|c|c|c|c|c|c|c|c|}
\hline $\begin{array}{l}\text { Reactor } \\
\text { Condition }\end{array}$ & $\begin{array}{c}\text { Recovered } \\
\left(\mathrm{cfu} * 10^{9}\right)\end{array}$ & $\begin{array}{c}\text { Inoculum } \\
\left(\mathrm{cfu} * 10^{9}\right)\end{array}$ & $\begin{array}{c}\text { Percent } \\
\text { Recovered } \\
(\%)\end{array}$ & $\begin{array}{l}\text { Reactor } \\
\text { Condition }\end{array}$ & $\begin{array}{c}\text { Recovered } \\
\left(\mathrm{cfu} * 10^{9}\right)\end{array}$ & $\begin{array}{c}\text { Percent } \\
\text { Inoculum } \\
\left(\mathrm{cfu} * 10^{9}\right)\end{array}$ & $\begin{array}{c}\text { Recovered } \\
(\%)\end{array}$ \\
\hline Control & 1.56 & 1.22 & 127 & Thin & 0.76 & 1.11 & 68 \\
\hline Control & 1.01 & 0.73 & 138 & Thin & 0.95 & 1.11 & 85 \\
\hline Control & 1.54 & 1.82 & 85 & Thin & 1.15 & 1.05 & 109 \\
\hline Control & 0.53 & 0.46 & 116 & Thin & 1.30 & 1.00 & 130 \\
\hline Control & 2.07 & 1.38 & 150 & Thin & 1.74 & 1.78 & 98 \\
\hline Control & 1.41 & 1.70 & 83 & Thick & 1.40 & 1.40 & 100 \\
\hline Control & 1.09 & 1.06 & 103 & Thick & 0.86 & 0.77 & 111 \\
\hline
\end{tabular}

Table 3. Percent recoveries for E. coli $\mathrm{O} 157: \mathrm{H} 7$ 
Plate counts were used to determine the total number of E. coli $\mathrm{O} 157: \mathrm{H} 7$ cells remaining in reactors after $820 \mathrm{~s}$ of continuous flow (Figure 8). Each bar represents the mean of all experiments of each type with error bars displaying inter-experiment standard deviations. The term 'pore fluid' refers to cells that were recovered from the freely-

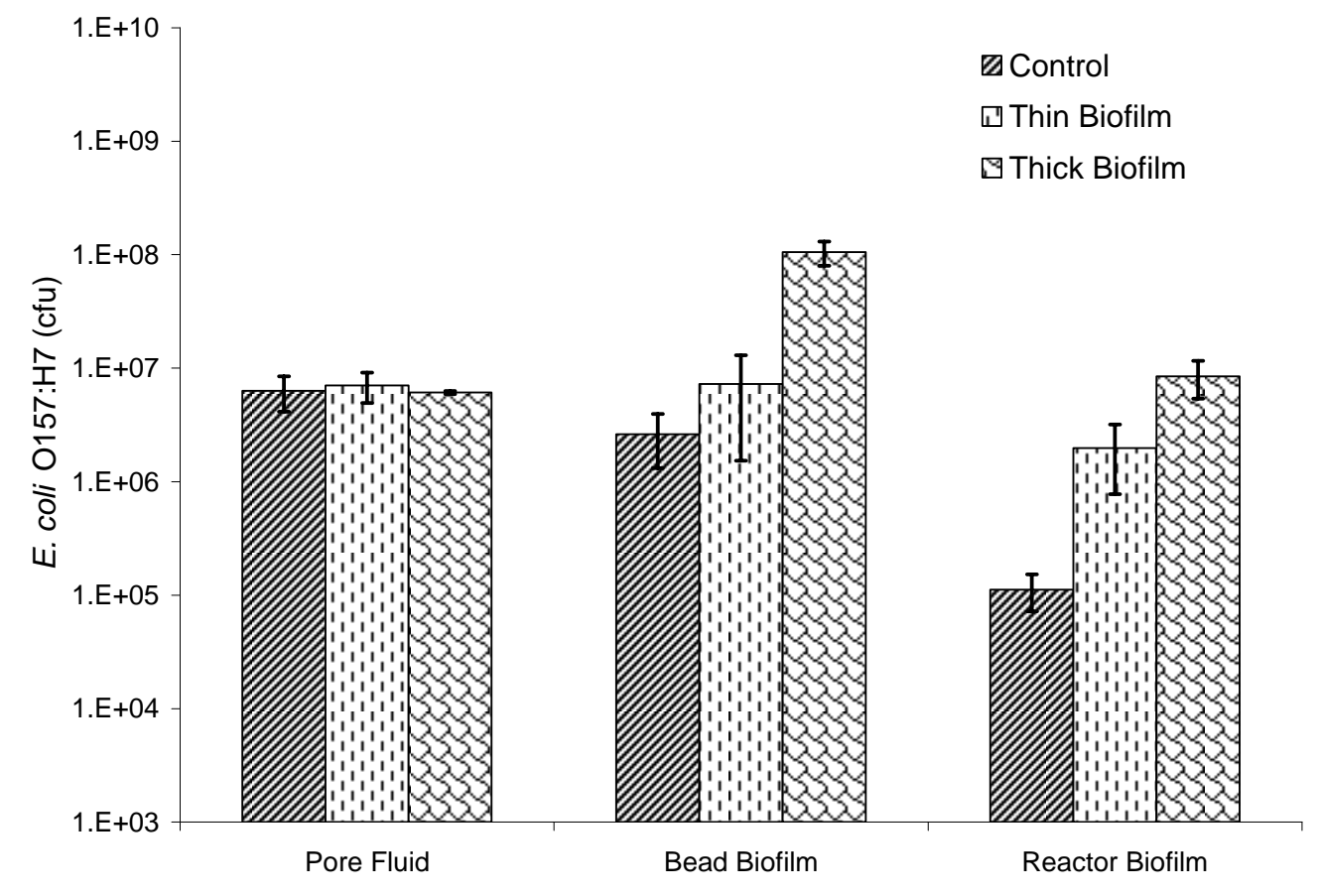

Figure 8. Total number of E. coli O157:H7 within reactors, $\mathrm{n}=7$ for control, $\mathrm{n}=5$ for thin, and $\mathrm{n}=2$ for thick

flowing pore fluid drained from the reactor prior to destructive sampling. 'Bead biofilm' refers to cells either attached to glass beads for control experiments, or recovered from biofilm that was harvested from glass beads for biofilm experiments. Lastly, 'reactor biofilm' refers to cells either attached to reactor surfaces or recovered from biofilm that was harvested from reactor surfaces. E. coli $\mathrm{O} 157: \mathrm{H} 7$ concentrations in pore fluid 
samples did not vary significantly between the three reactor conditions. For thin biofilm experiments, the number of $E$. coli $\mathrm{O} 157: \mathrm{H} 7$ cells in bead biofilm samples increased approximately 0.5 orders of magnitude whereas the number in reactor biofilm samples increased by approximately 1.5 orders of magnitude. For thick biofilm experiments the increase was around 2 orders of magnitude for both bead and reactor biofilm samples.

E. coli $\mathrm{O} 157: \mathrm{H} 7$ concentrations in effluent samples were also determined by plate counts. The average total number of $E$. coli $\mathrm{O} 157: \mathrm{H} 7$ cells in each sample plotted versus sample number (Figure 9). Each bar represents the mean of all experiments of each type with error bars displaying inter-experiment standard deviations. The three reactor conditions showed a similar trend for E. coli $\mathrm{O} 157: \mathrm{H} 7$ washout from the reactor - cell

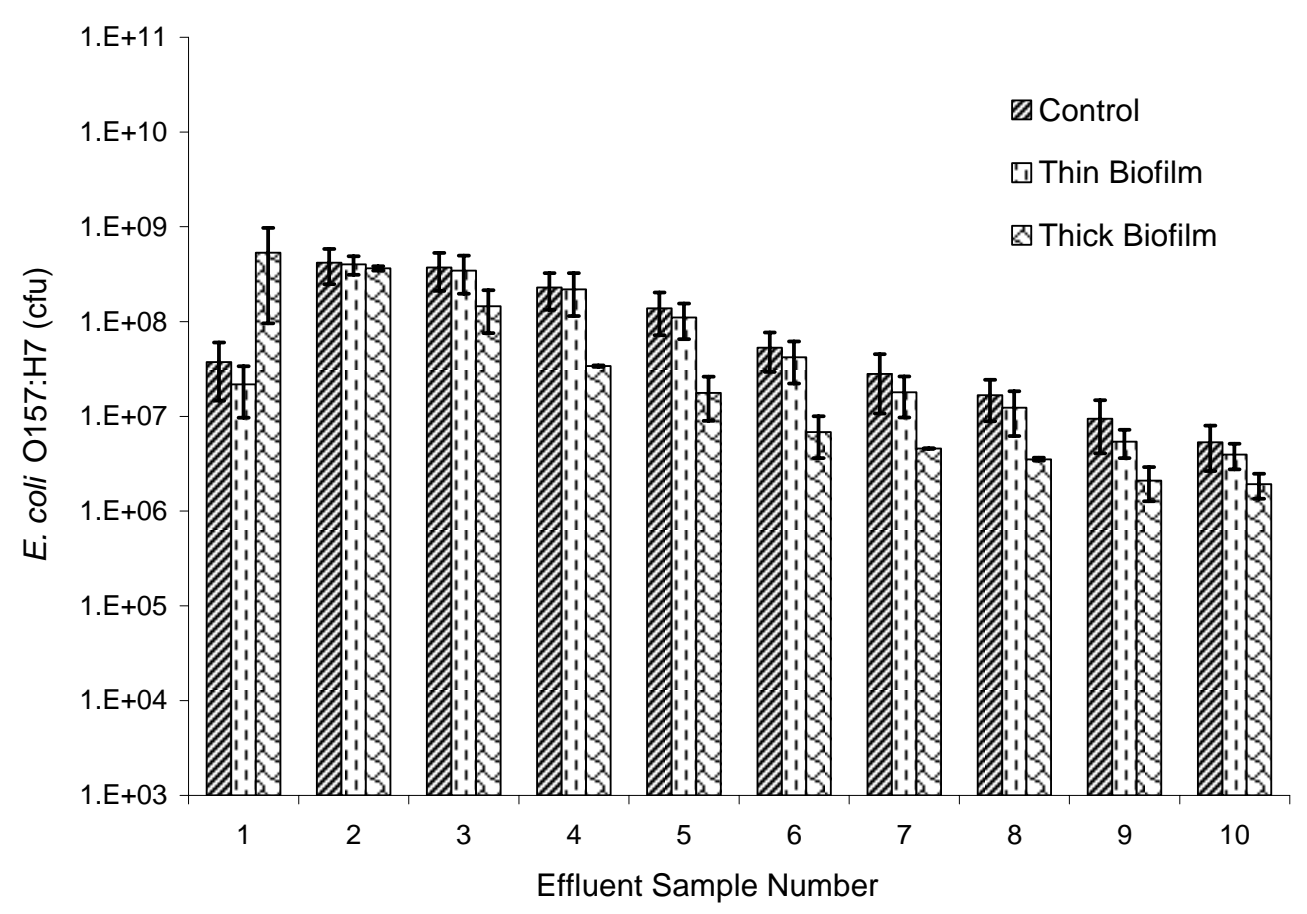

Figure 9. Total number of $E$. coli $\mathrm{O} 157: \mathrm{H} 7$ in effluent samples collected over $82 \mathrm{~s}, \mathrm{n}=7$ for control, $\mathrm{n}=5$ for thin, and $\mathrm{n}=2$ for thick 
numbers peak early after inoculation and decrease gradually over the 820 s sampling period. Also, it appears that more cells leave the reactor earlier when biofilm is present, resulting in lower concentrations of $E$. coli $\mathrm{O} 157: \mathrm{H} 7$ in later samples.

\section{Breakthrough Curves}

The rates at which E. coli $\mathrm{O} 157: \mathrm{H} 7$ cells passed through reactors were described using breakthrough curves. A breakthrough curve is defined here as the average concentration of $E$. coli $\mathrm{O} 157: \mathrm{H} 7$ observed in effluent samples for each reactor condition (C), normalized to average inocula concentrations $\left(\mathrm{C}_{\mathrm{o}}\right)$, plotted versus the pore volume in which they were recovered (Figure 10). Because the free pore space within the reactors decreased as biofilm accumulated, each $34.44 \mathrm{ml}$ effluent sample $\left(\mathrm{V}_{\mathrm{S}}=25 \mathrm{ml} / \mathrm{min} \mathrm{x} 82 \mathrm{~s}\right)$

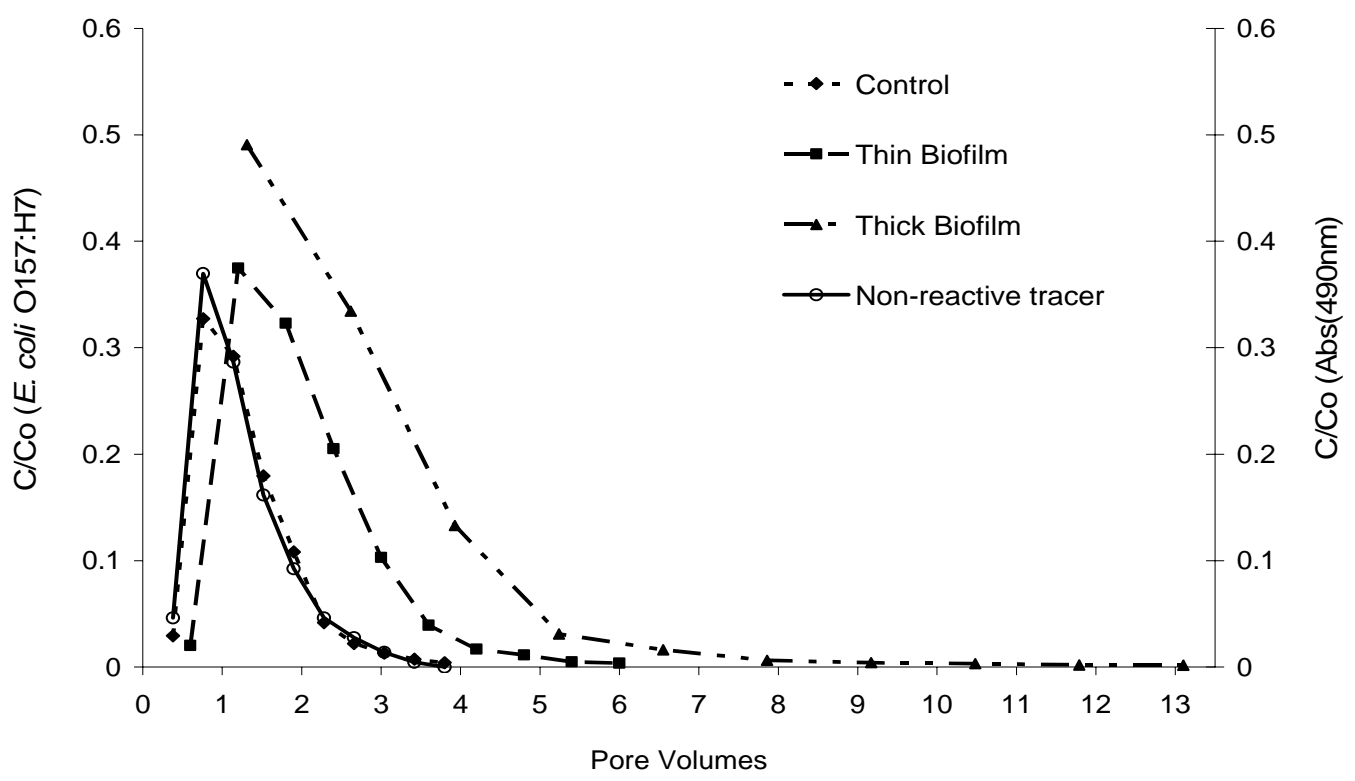

Figure 10. Breakthrough curves. Co $=1.27 \times 10^{9}$ for control experiments, $1.07 \times 10^{9}$ for thin biofilm experiments, $1.09 \times 10^{9}$ for thick biofilm experiments and 7.4 for the non-reactive tracer 
contained a different fraction of one pore volume for each reactor condition. The average fraction of a pore volume $\left(P V_{F r a c}\right)$ was calculated for each biofilm condition using Equation 1, where $\mathrm{V}_{\mathrm{s}}$ was constant and $\mathrm{V}_{\mathrm{p}}$ was measured during each experiment and averaged for each reactor condition. Based on this formula, each effluent sample

$$
\frac{V_{S}}{\overline{V_{P}}}=P V_{\text {Frac }}
$$

Equation 1. Average fraction of one pore volume collected in each effluent sample

contained 0.38 pore volumes for control reactors, 0.59 pore volumes for thin biofilm reactors, and 1.31 pore volumes for thick biofilm reactors.

The breakthrough curve for E. coli O157:H7 cells traveling through control reactors was similar to the breakthrough curve for the non-reactive tracer which served as a control. However, reactors colonized with biofilm exhibit greater dispersion as well as a prolonged washout of $E$. coli $\mathrm{O} 157: \mathrm{H} 7$ relative to the non-reactive tracer. The degree to which cells were slowed with respect to the bulk fluid can be quantified using retardation factors $\left(\mathrm{R}_{\mathrm{f}}\right)$.

\section{$\underline{\text { Retardation Factors }}$}

A retardation factor $\left(\mathrm{R}_{\mathrm{f}}\right)$ is defined here as the ratio of the mean cell residence time to the hydraulic residence time (Johnson et al, 1998) and quantifies the attenuation of cells as they travel through porous media (Table 4). Average hydraulic residence times $\left(\theta_{H}\right)$ (Table 4$)$ were calculated for each reactor condition using equation 2 . The flow rate, $Q$, was constant $(25 \mathrm{ml} / \mathrm{min})$ and the volume of free pore space, $V_{P}$, was measured for 


\begin{tabular}{|c|c|c|c|}
\hline & $\begin{array}{c}\text { Ave. hydraulic } \\
\text { residence times, } \theta_{\mathrm{h}}(\mathrm{s})\end{array}$ & $\begin{array}{c}\text { Ave. mean cell } \\
\text { residence times, } \theta \mathrm{c}(\mathrm{s})\end{array}$ & $\begin{array}{c}\text { Ave. retardation factors, } \\
\mathrm{R}_{\mathrm{f}}=\theta_{\mathrm{c}} / \theta_{\mathrm{h}}\end{array}$ \\
\hline Non-reactive tracer & 212 & 223.1 & 1.05 \\
\hline Control & 212 & 234.9 & 1.11 \\
\hline Thin Biofilm & 139.7 & 226.9 & 1.74 \\
\hline Thick Biofilm & 63.6 & 110.7 & 1.62 \\
\hline
\end{tabular}

Table 4. Average hydraulic residence times, mean cell residence times and retardation factors

each experiment. Average mean cell residence times $\left(\theta_{C}\right)$ (Table 4) were calculated for each reactor condition using equation 3 , where time was the time at which the corresponding concentrations of $E$. coli $\mathrm{O} 157: \mathrm{H} 7$ were observed in the effluent and $\mathrm{N}$ is the number of experiments of each type.

$$
\frac{\overline{V_{P}}}{Q}=\theta_{H}
$$

Equation 2. Average hydraulic residence time

$$
\frac{\sum_{i=1}^{N}\left(\frac{\sum([\text { E.coli }] * \text { time }}{\sum \text { E.coli }}\right)}{N}=\theta_{C}
$$

Equation 3. Average mean cell residence time

\section{$\underline{\text { Immobilization Efficiency }}$}

The total number of cells remaining immobilized within the reactor after $820 \mathrm{~s}$ was considered the sum of cells from bead biofilm and reactor biofilm samples. The 
average numbers of immobilized cells were calculated for each reactor condition and compared with the average number of cells in the corresponding inocula, (Figure 11).

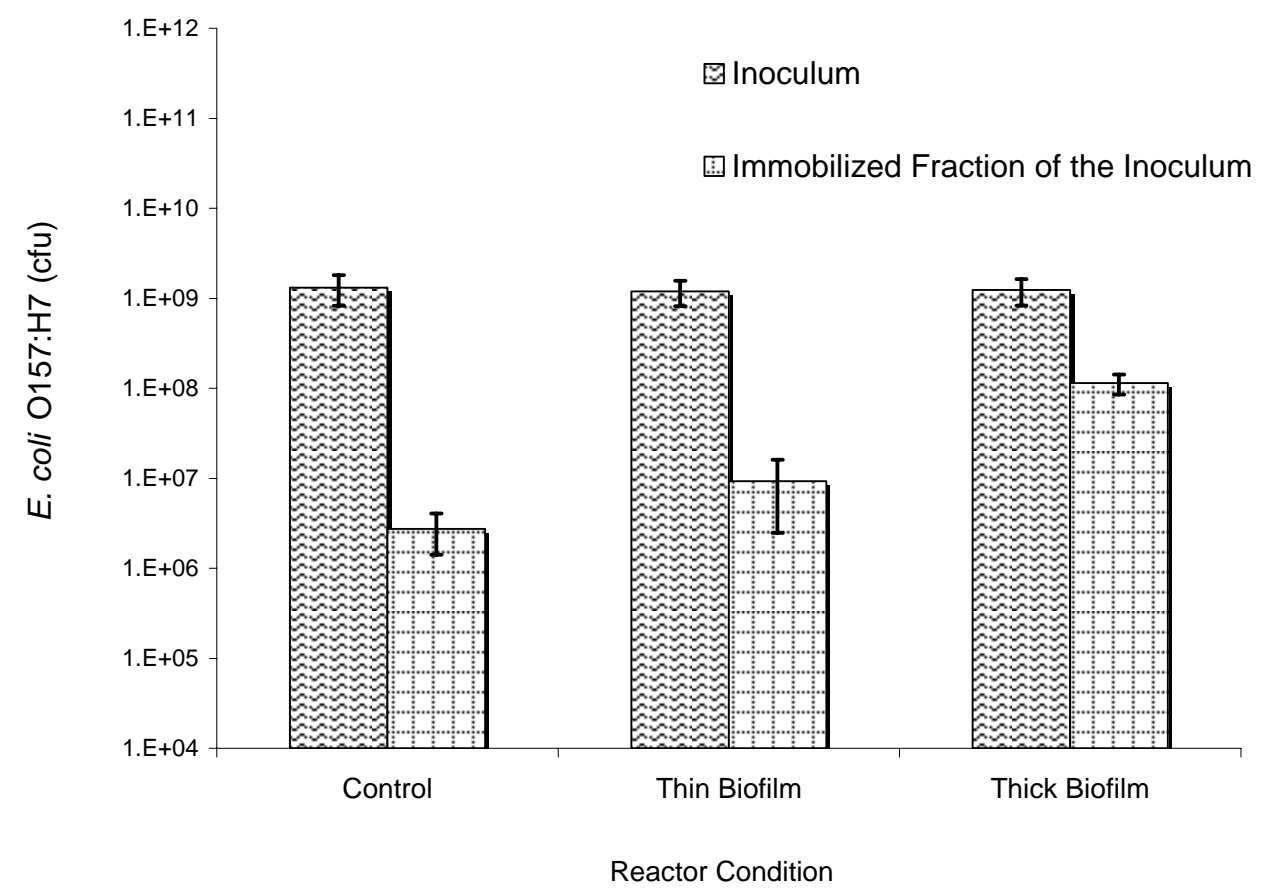

Figure 11. Average total number of E. coli $\mathrm{O} 157: \mathrm{H} 7$ in inocula, and the average immobilized fraction of inocula

On average, control reactors immobilized $0.22 \%$ of cells from the inoculum, thin biofilm reactors $0.75 \%$ and thick biofilm reactors $9.37 \%$. The differences in immobilization between the three reactor conditions are statistically significant at the 0.05 level $(p=0.02$ between control and thin, $p<0.001$ between control and thick and $p$ $<0.001$ between thin and thick). 


\section{Direct Counts}

Direct counts of E. coli O157:H7, based on fluorescent microscopy, were compared with the corresponding plate counts (considered the standard) for selected samples (Figures 12-14). Concentrations of E. coli O157:H7 are plotted versus sample

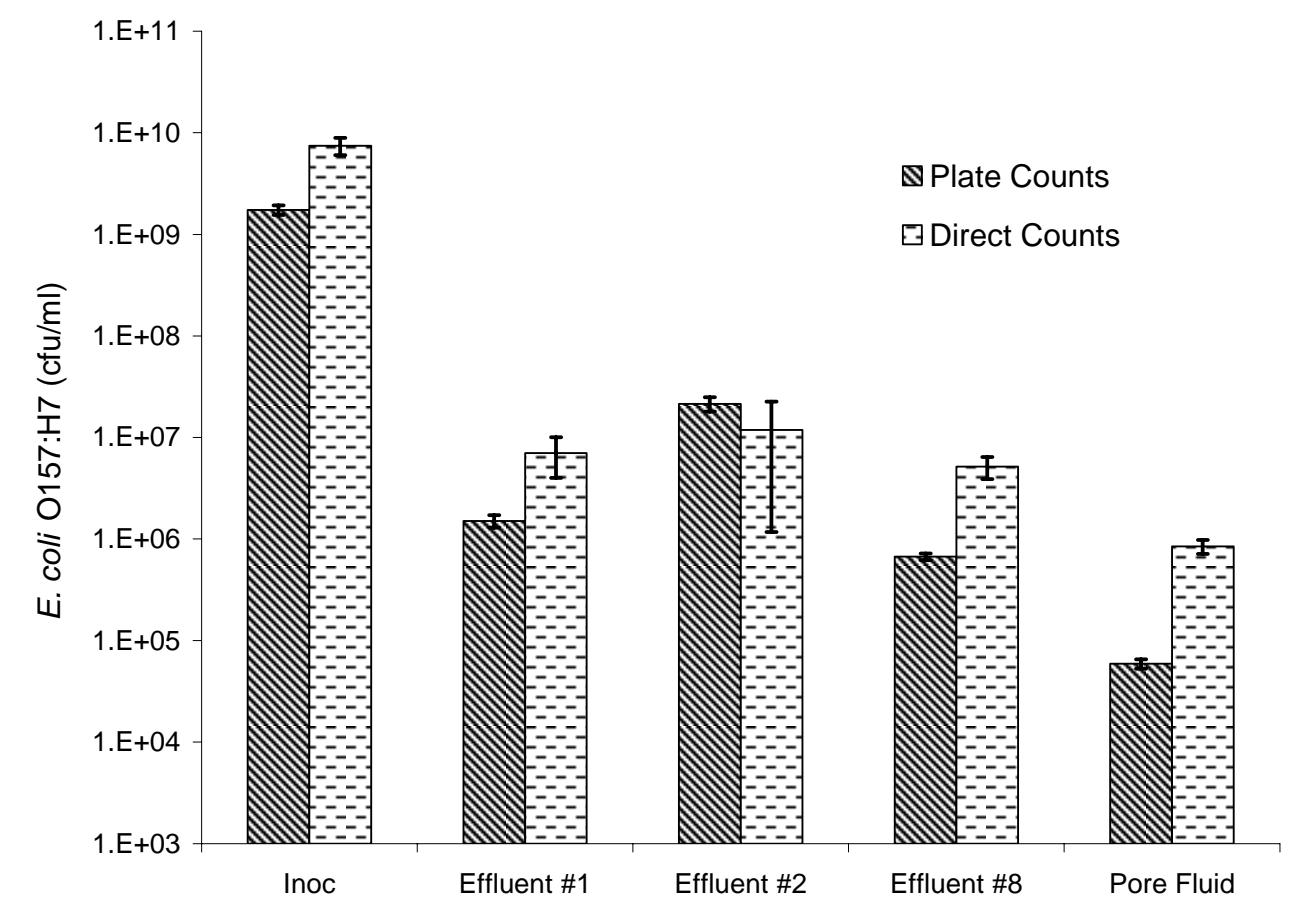

Figure 12. Plate counts compared with direct counts for control experiment \#5

name and error bars represent intra-sample standard deviations. Of these comparisons, one example from each biofilm condition is presented here. The remaining comparisons between direct counts and plate counts can be found in Appendix A. 


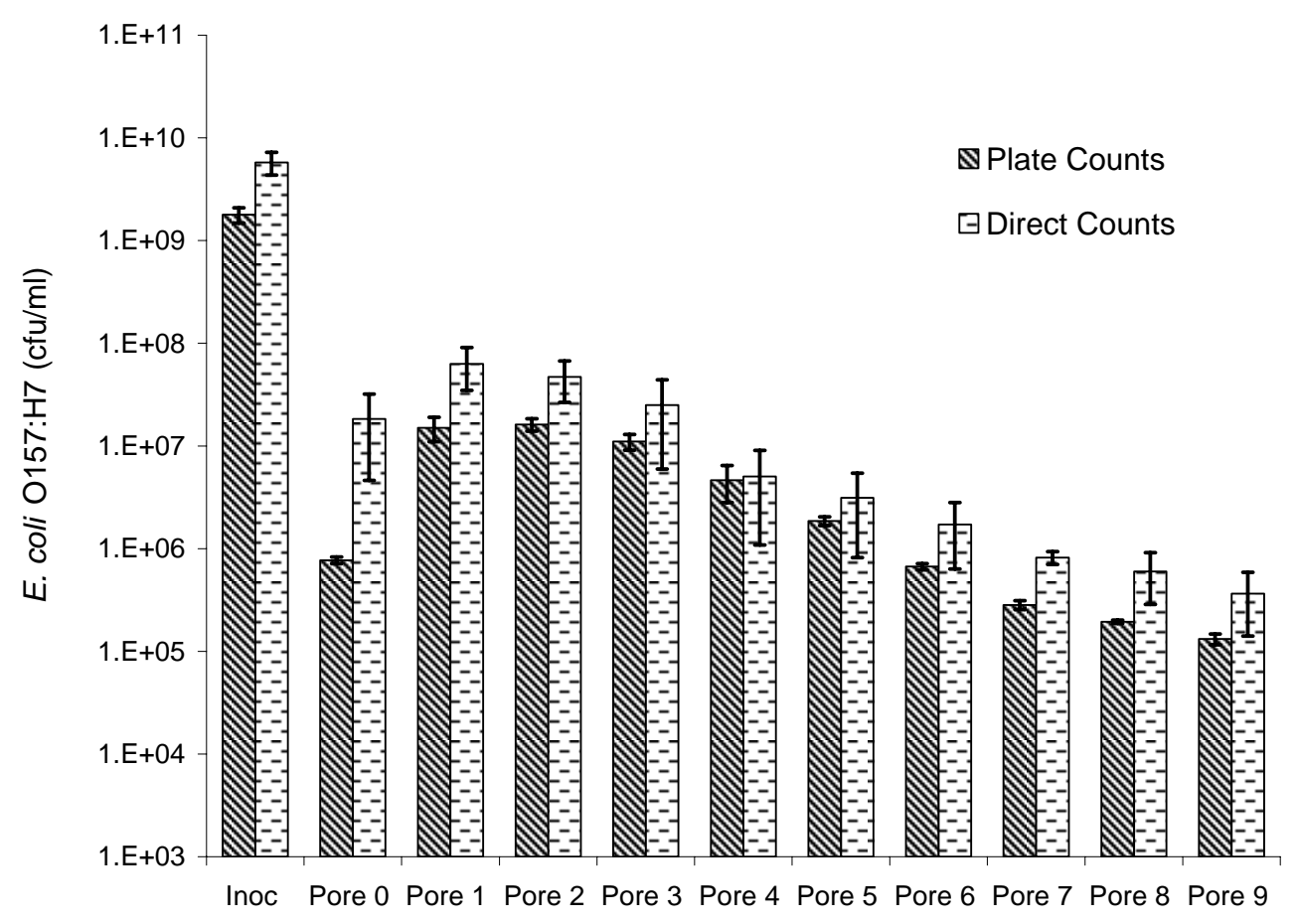

Figure 13. Plate counts compared with direct counts for thin biofilm experiment \#5

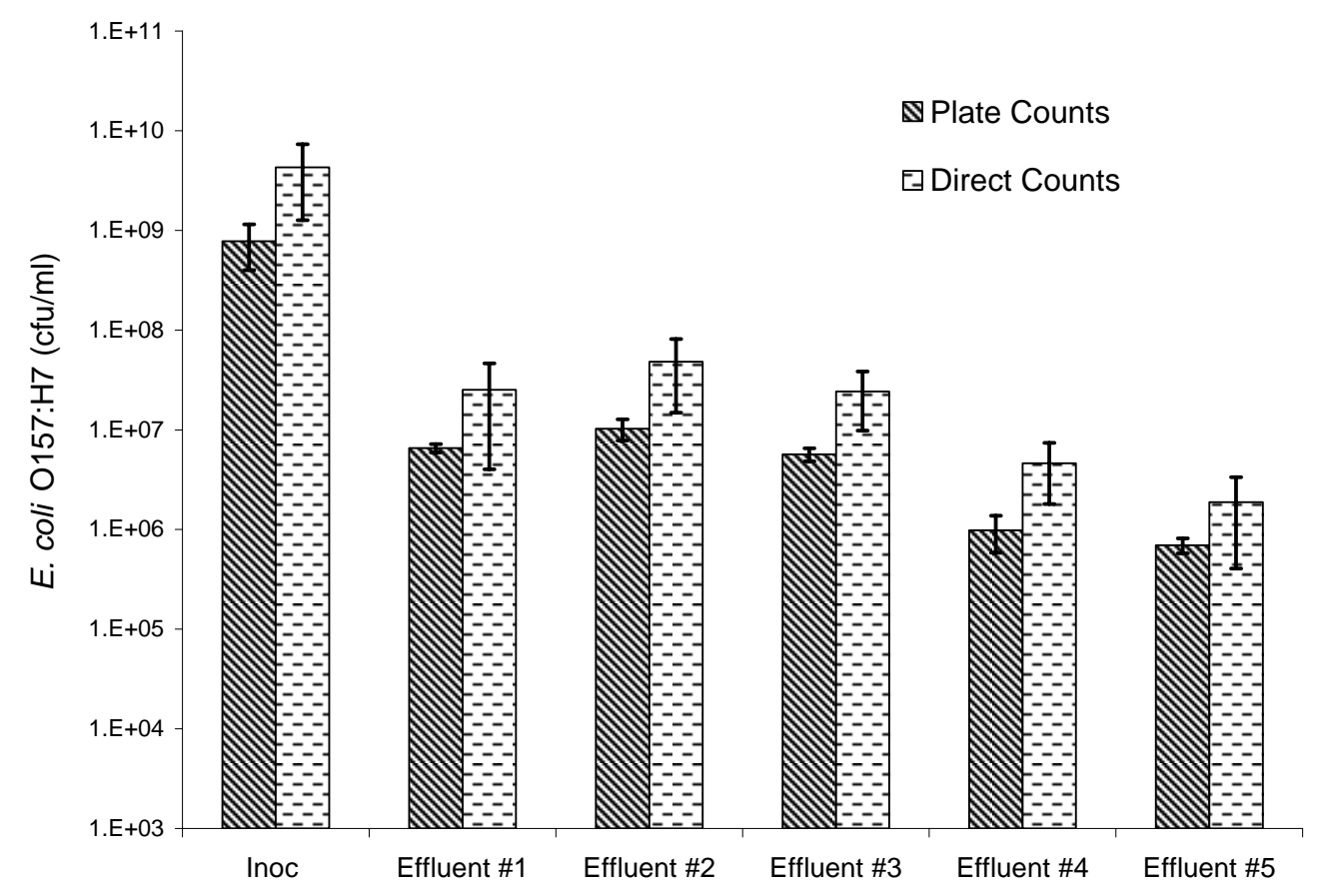

Figure 14. Plate counts compared with direct counts for thick biofilm experiment \#2 
Direct counts consistently overestimated the number of E. coli $\mathrm{O} 157: \mathrm{H} 7$ relative to plate counts. This trend was independent of reactor conditions. For all experiments run the average $\log$ difference with which plate counts were overestimated was 0.6 .

\section{Quantitative PCR}

Quantitative PCR was used as a third method to determine concentrations of $E$. coli $\mathrm{O} 157: \mathrm{H} 7$. Obtained values were compared with the numbers obtained from plate counting (Figures 15-20 \& 26-39). For each experiment, two figures are presented: the first showing concentrations of cells in effluent samples and the second showing the concentrations of cells remaining in the reactor after flow was stopped. One example from each experiment type is shown. The remaining comparisons between quantitative PCR and plate counts can be found in Appendix B.

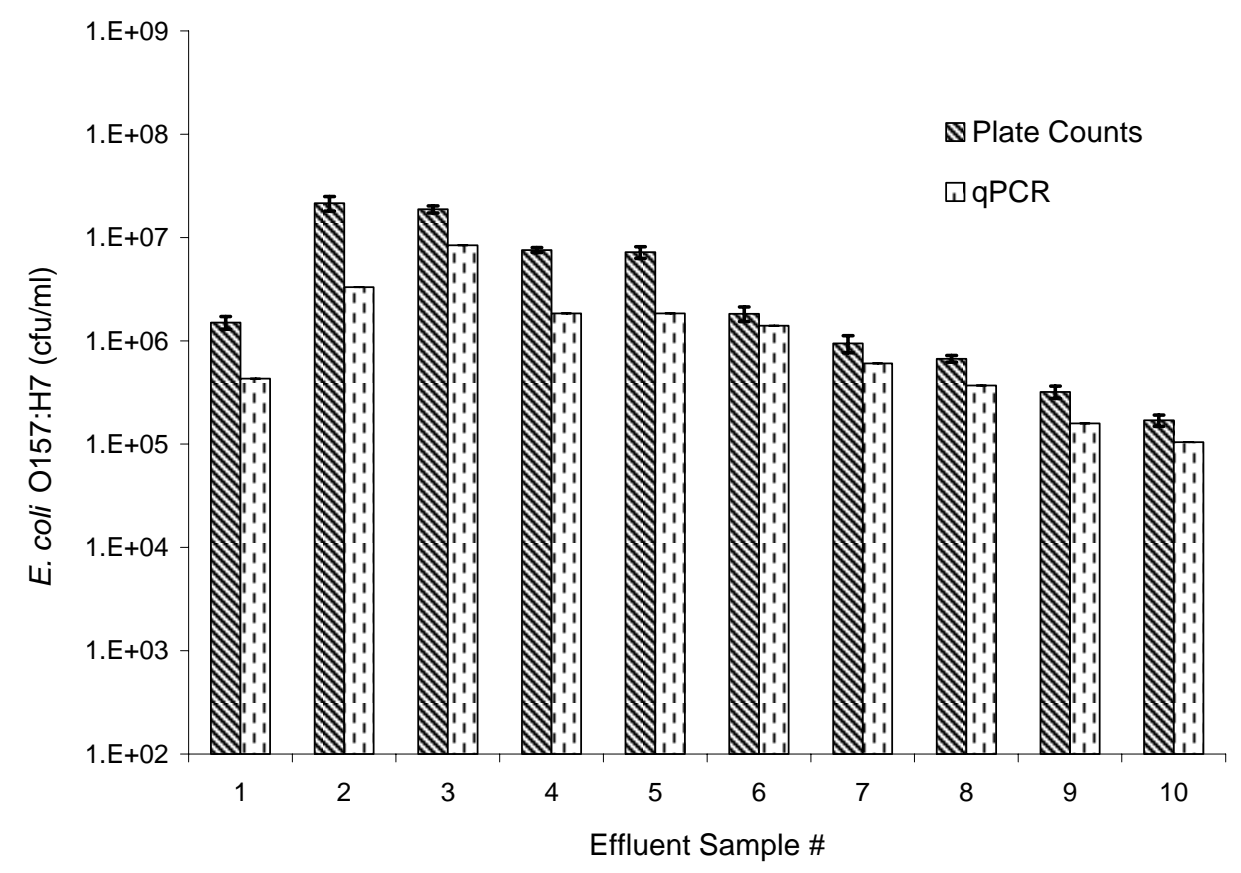

Figure 15. Plate counts compared with qPCR for effluent samples from control experiment \#5 


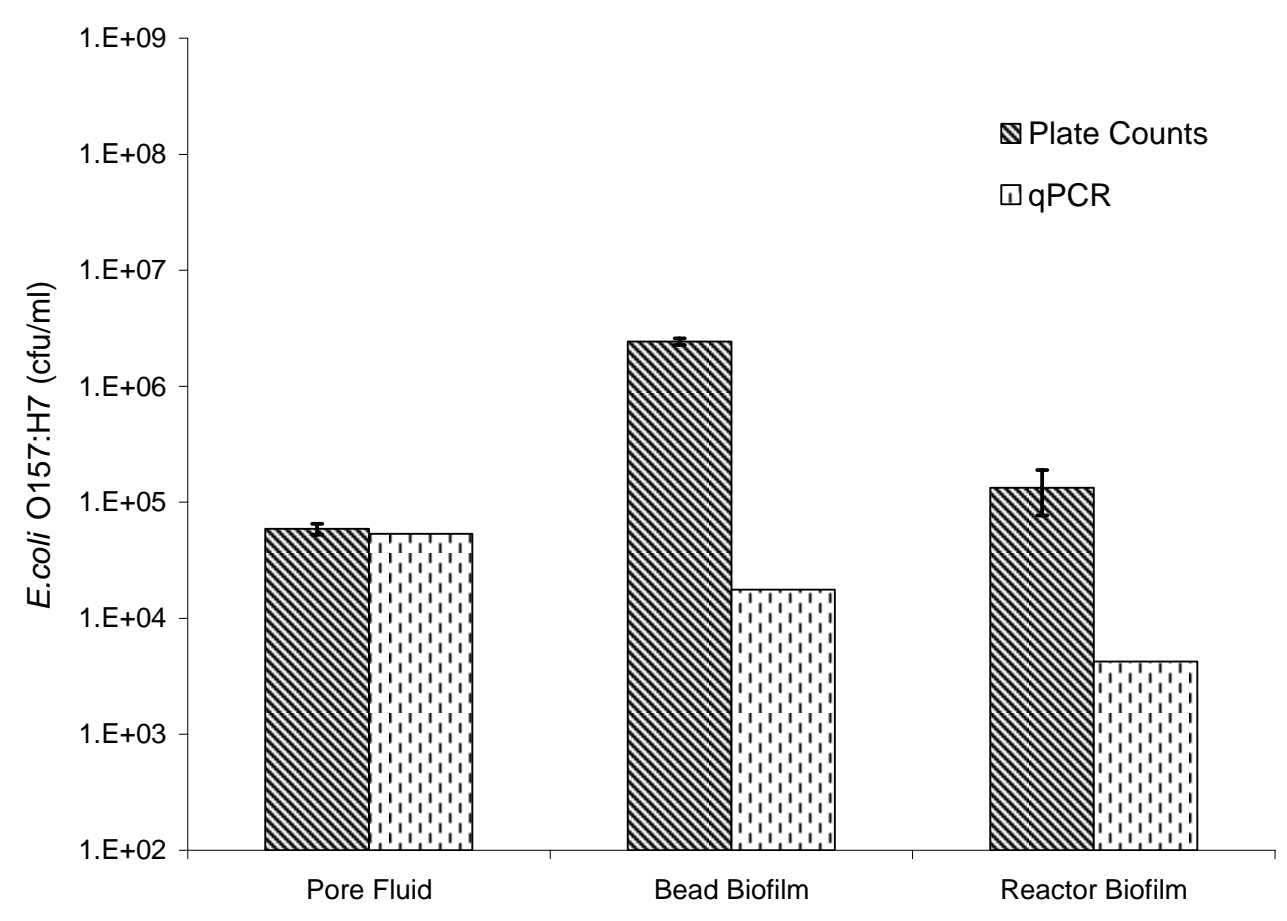

Figure 16. Plate counts compared with qPCR for control experiment \#5

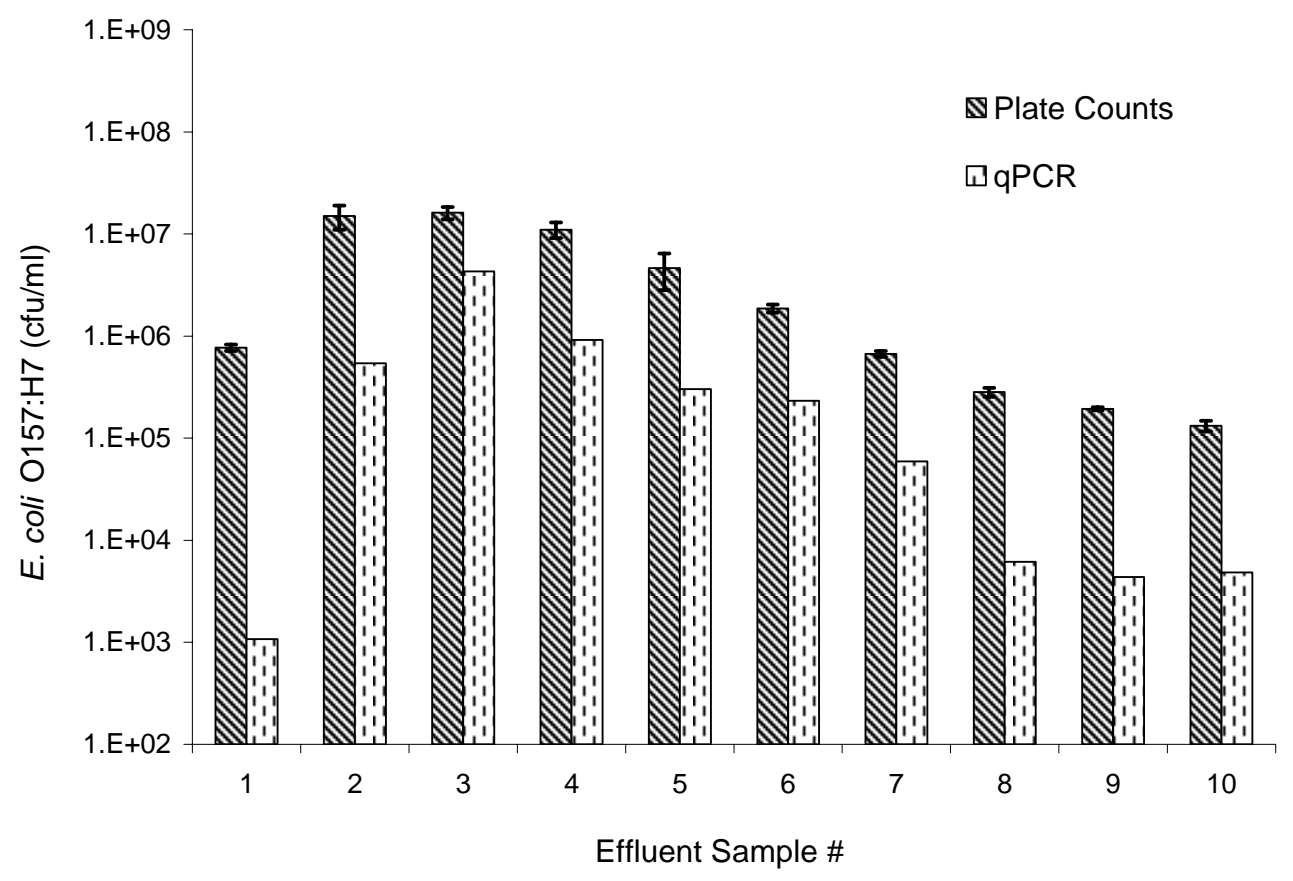

Figure 17. Plate counts compared with qPCR for effluent samples from thin biofilm experiment \#5 


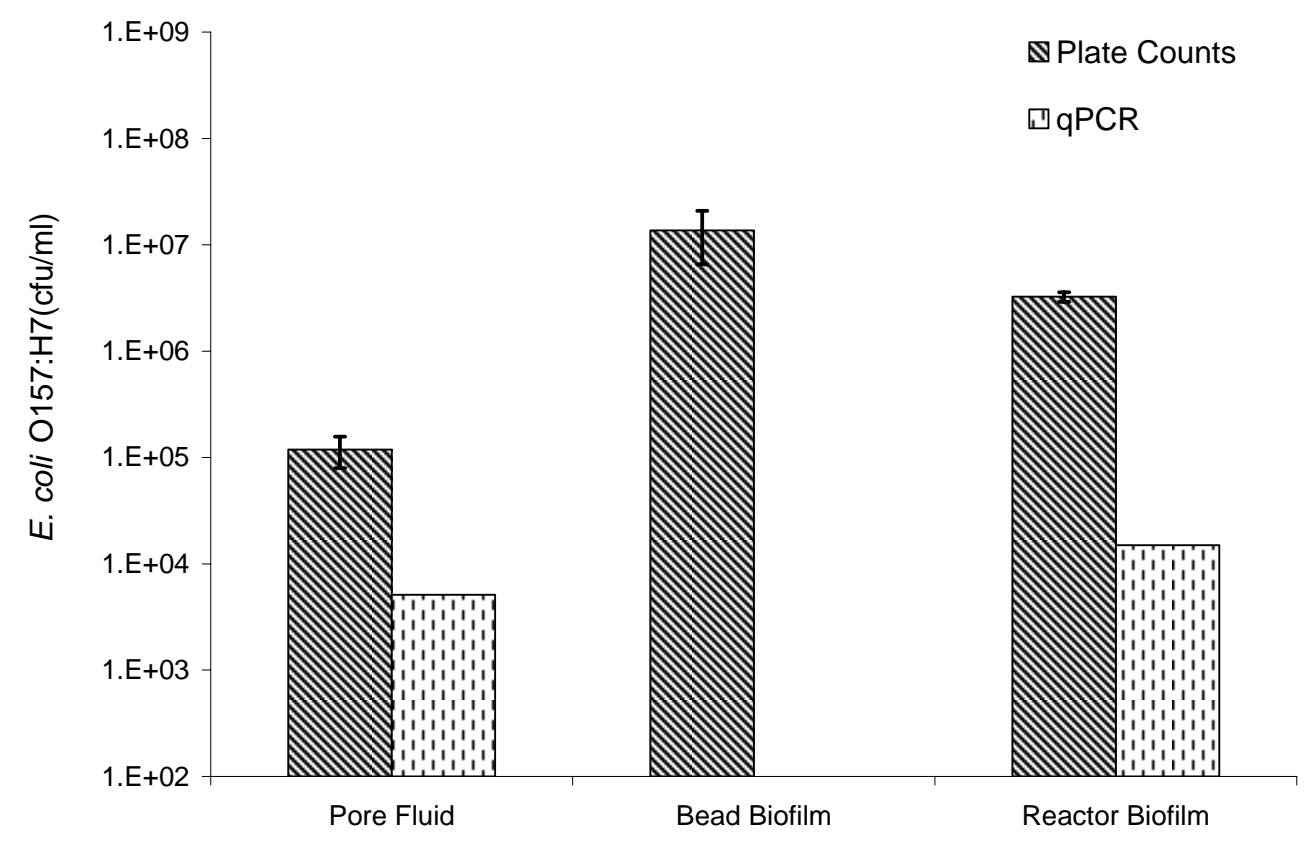

Figure 18. Plate counts compared with qPCR for thin biofilm experiment $\# 5$

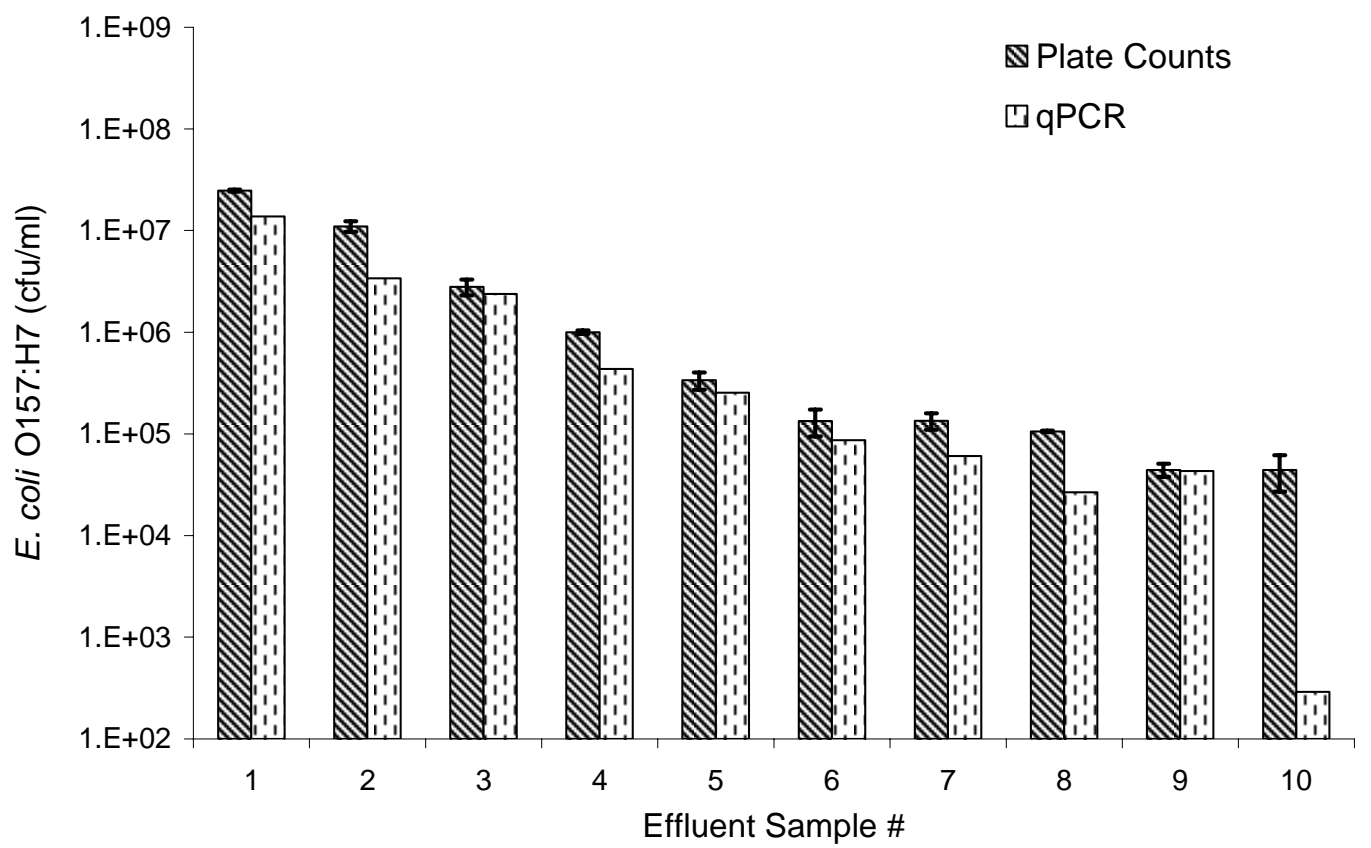

Figure 19. Plate counts compared with qPCR for effluent samples from thick biofilm experiment \#2 


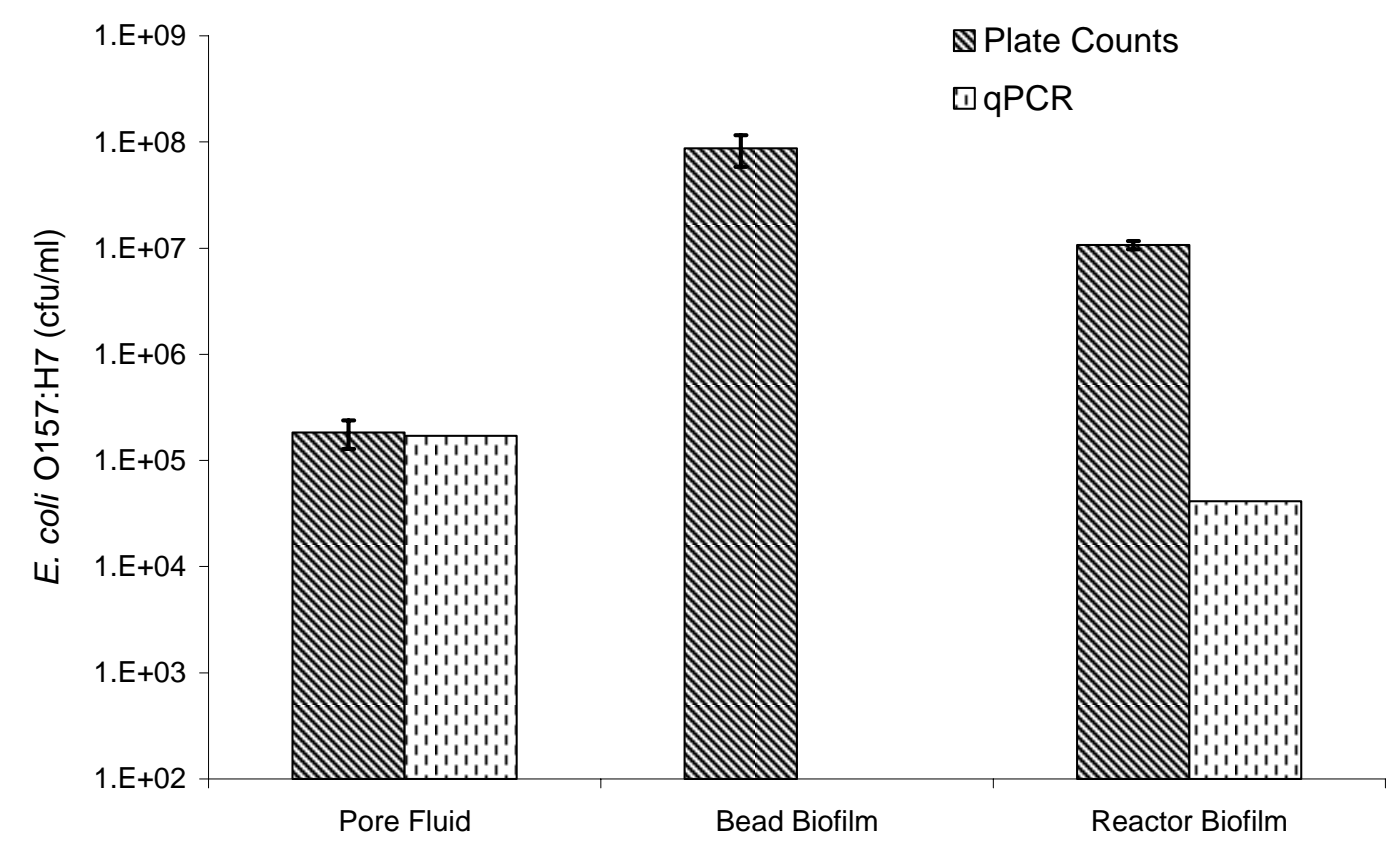

Figure 20. Plate counts compared with qPCR for thick biofilm experiment \#2

qPCR data from control experiments, with a few exceptions, underestimated plate counts. For effluent samples from control experiments, qPCR data reflected plate counts rather closely in most cases with approximately $15 \%$ of samples exhibiting underestimations of 1-2.5 orders of magnitude and one sample that did not detect any $E$. coli O157:H7 (Figures 15, 26, 28, 30) For pore fluid samples, qPCR data and plate counts varied only slightly; however, qPCR for bead and reactor biofilm samples routinely underestimated the concentrations of $E$. coli $\mathrm{O} 157: \mathrm{H} 7$ relative to plate counts by between 1 and 3 orders of magnitude (Figures 16, 27, 29, 31).

For effluent samples from thin biofilm experiments, qPCR again underestimated most $E$. coli $\mathrm{O} 157: \mathrm{H} 7$ concentrations for effluent samples relative to plate counts, although qPCR failed to detect any E. coli $\mathrm{O} 157: \mathrm{H} 7$ in 5\% of effluent samples (Figures 
17, 32, 34, 36). For thin biofilms, qPCR data for pore fluid, bead biofilm, and reactor biofilm samples from 2 out of 4 experiments underestimated concentrations relative to plate counts by $0.2-3$ orders of magnitude. Thin biofilm experiment \#3 overestimated plate counts by $0.5-2$ orders of magnitude and experiment $\# 5$ failed to detect $E$. coli O157:H7 in the bead biofilm sample (Figures 18, 33, 35, 37).

Lastly, qPCR data from thick biofilm experiments exhibited similar trends as control and thin biofilm experiments, except that $E$. coli $\mathrm{O} 157: \mathrm{H} 7$ could not be detected in bead biofilm samples from either experiment (Figures 20 \& 39). Plate counts and qPCR for effluent samples varied only slightly in experiment 1 with the exception of sample 10 in which qPCR underestimated the plate counts by 2.5 orders of magnitude (Figure 38). Differences for effluent samples from experiment 2 are not consistent and vary from 0.1-2 orders of magnitude (Figure 19).

Differences between qPCR data and plate counts for enumerating E. coli O157:H7 in effluent samples are consistently different within experiments for 7 out of 10 experiments, possibly revealing systematic errors. For samples obtained by destructively sampling reactors the trends are not as clear. Plate counts from pore fluid samples are more closely estimated by qPCR than bead and reactor biofilm samples. E. coli O157:H7 was detected by qPCR in all bead biofilm samples from control experiments, but only in $50 \%$ of samples from biofilm experiments. 


\section{$\underline{\text { PCR Inhibition Assays }}$}

The possible inhibition of qPCR by the presence of a drinking water biofilm was investigated. The first assay compared $\mathrm{C}_{\mathrm{t}}$ values from qPCR for five concentrations of $E$. coli O157:H7 DNA quantified in the presence of either PCR-grade water or purified genomic DNA from homogenized biofilm (Figure 21).

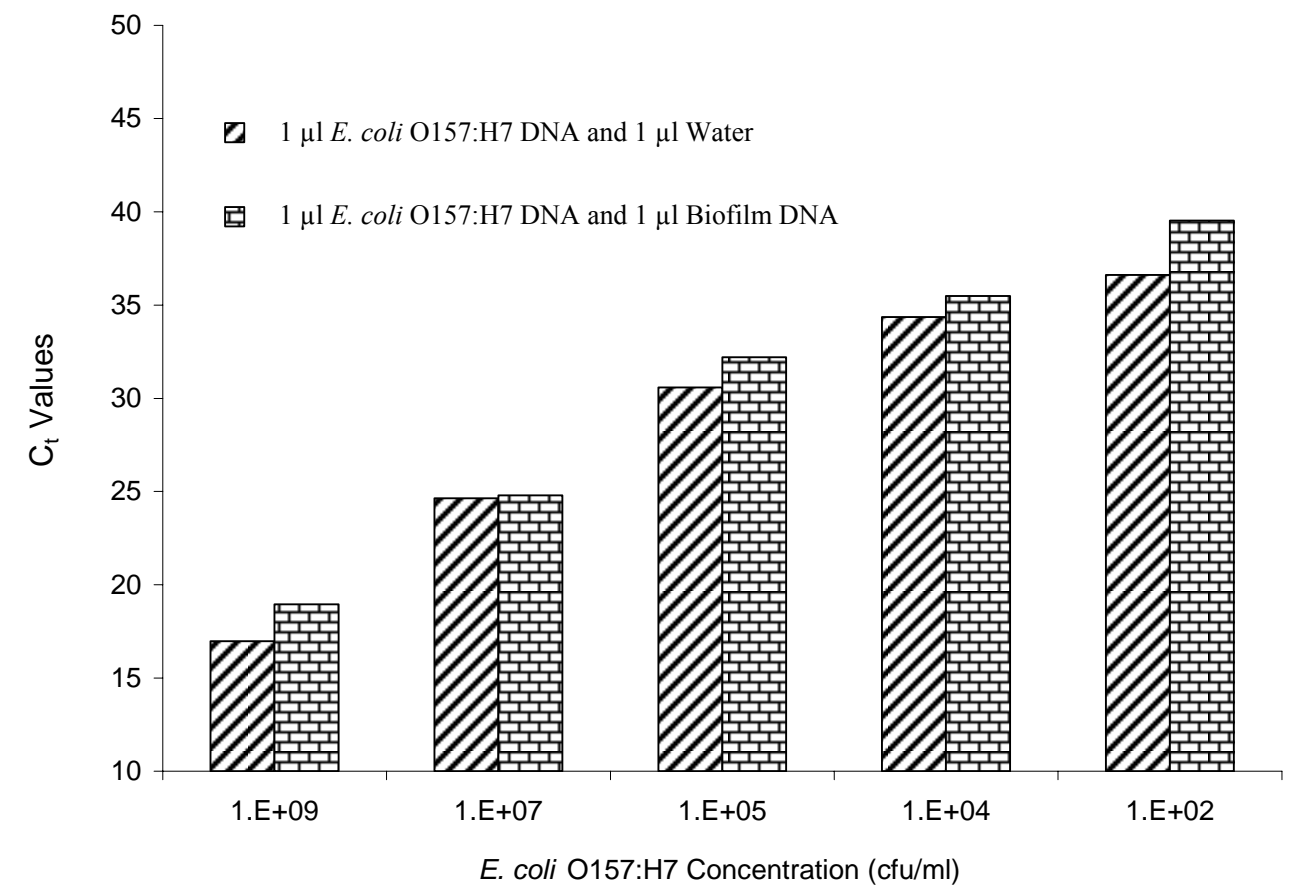

Figure 21. $\mathrm{C}_{\mathrm{t}}$ values from qPCR for five concentrations of $E$. coli $\mathrm{O} 157: \mathrm{H} 7$ enumerated in the presence of either PCR-grade water or purified genomic DNA from a drinking water biofilm

Consistent with some form of inhibition, $\mathrm{Ct}$ values from $\mathrm{qPCR}$ performed with a mixture of $E$. coli $\mathrm{O} 157: \mathrm{H} 7 \mathrm{DNA}$ and biofilm DNA were higher than those performed with $E$. coli $\mathrm{O} 157: \mathrm{H} 7 \mathrm{DNA}$ mixed with water. The average difference was 1.6 cycles, 
which based on PCR-reaction theory corresponds to about 0.5 orders of magnitude difference in starting E. coli O157:H7 DNA template concentration.

The second assay compared $\mathrm{C}_{\mathrm{t}}$ values from qPCR for a sample of approximately 1 x $10^{9} \mathrm{cfu} / \mathrm{ml}$ E. coli $\mathrm{O} 157: \mathrm{H} 7$ whose DNA was extracted in the presence of various concentrations of homogenized biofilm (Figure 22). Data is presented as the difference in

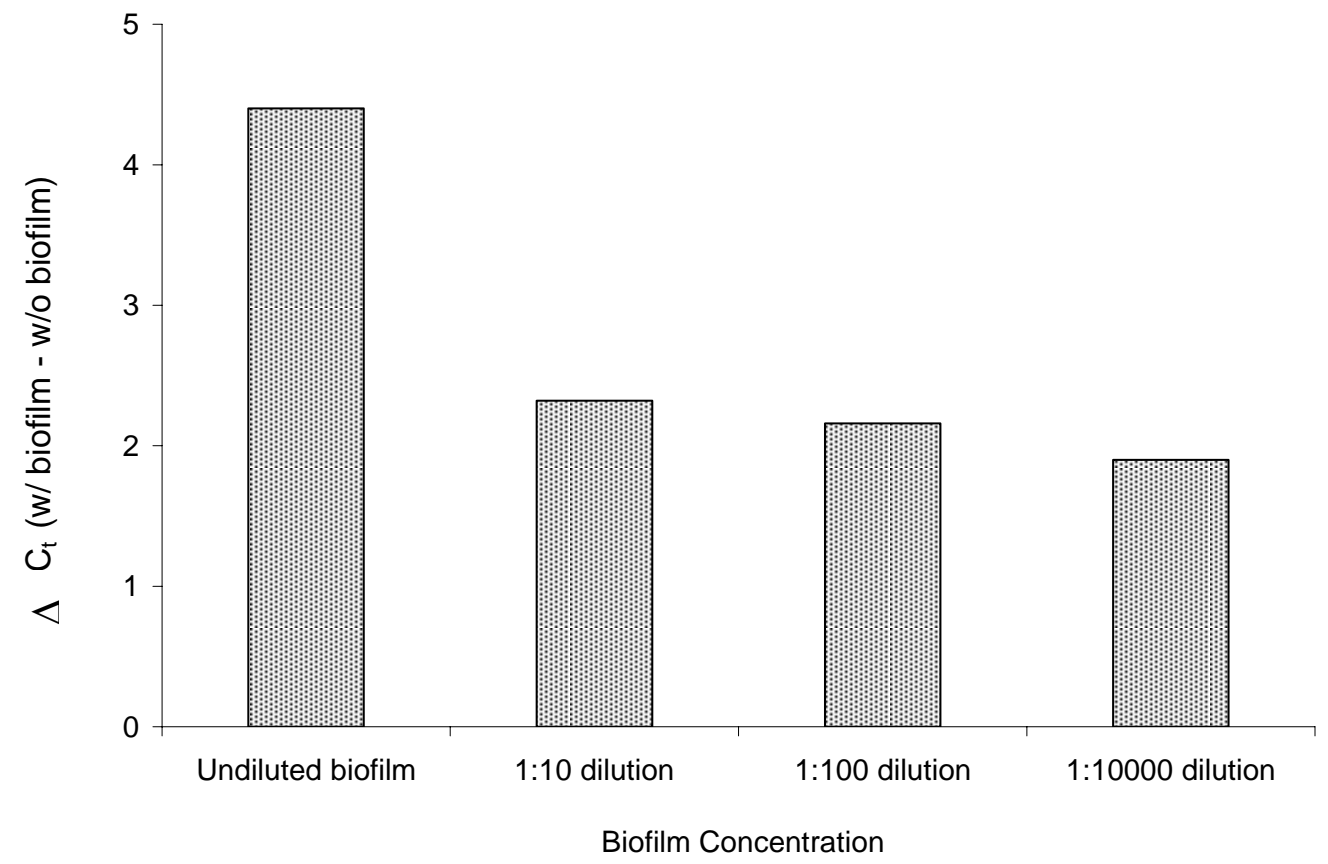

Figure 22. Change in $\mathrm{C}_{\mathrm{t}}$ values from qPCR between samples of $E$. coli $\mathrm{O} 157: \mathrm{H} 7$ whose DNA was extracted in the presence of biofilm and a control where no biofilm was present during extraction

$\mathrm{C}_{\mathrm{t}}$ value between the samples containing biofilm and a positive control that had no biofilm. A difference of 4.5 cycles, corresponding to about 1.5 orders of magnitude difference in E. coli O157:H7 concentration was observed with undiluted biofilm. 
Diluting the biofilm 10-fold decreased this difference significantly to around 2.25 cycles.

Further dilution had little effect on the change in $\mathrm{C}_{\mathrm{t}}$ values. 


\section{DISCUSSION}

The results presented in this study suggest that porous media reactors colonized with drinking water biofilms were able to immobilize significantly more E. coli $\mathrm{O} 157: \mathrm{H} 7$ than clean control reactors. The fraction of immobilized cells increased with increasing biofilm biomass in the reactor. Biofilms also contributed to greater dispersion and retardation of $E$. coli $\mathrm{O} 157: \mathrm{H} 7$ which prolonged the washout of cells.

\section{Transport Phenomena}

Changes in the hydrodynamic properties of porous media systems caused by the accumulation of biofilm have been investigated by a number of researchers. These investigations describe dynamic channel formation (Sharp et al, 2005), reduced porosity (Dunsmore et al, 2004; Tiwari \& Bowers, 2004), reduced permeability (Tiwari \& Bowers, 2004), and increased friction factors (Cunningham et al, 1991). A similar investigation which aimed at describing flow in biofilm-colonized porous media observed increased dispersion and accelerated breakthrough of a non-reactive tracer (Sharp et al, 1999). Unlike these investigations, the laboratory-scale reactor system used in these experiments did not allow direct observations of biofilm thickness or heterogeneity. As a result, hydrodynamics were described using a non-reactive tracer. An effort is made here to describe the transport of $E$. coli $\mathrm{O} 157: \mathrm{H} 7$ relative to the tracer and the influence of biofilm on E. coli $\mathrm{O} 157: \mathrm{H} 7$ transport.

The transport of $E$. coli $\mathrm{O} 157: \mathrm{H} 7$ through porous media reactors was described using breakthrough curves to normalize the differences in hydraulic residence times 
between reactor conditions (Figure 10). This graph demonstrates two possible influences of biofilm on the transport of $E$. coli $\mathrm{O} 157: \mathrm{H} 7$ through the porous media matrix preferential channeling and prolonged washout. Prolonged washout refers to the number of pore volumes required for $\mathrm{C} / \mathrm{C}_{\mathrm{o}}$ to approach zero and is affected by both dispersion (the flattening of the breakthrough curve) and retardation (the shifting of the centroid of breakthrough curves to the right). Prolonged washout was observed with thin and thick biofilm experiments with dispersion and retardation increasing with increasing biofilm biomass within reactors. Prolonged washout was interpreted as a consequence of interactions with biofilm. Preferential channeling occurs as biofilm accumulates heterogeneously within reactors, blocking or slowing flow through some areas of the reactor while increasing flow in others areas (Sharp, 1999), accelerating breakthrough. Preferential channeling may explain why the breakthrough of E. coli O157:H7 occurred earlier and at a higher concentration in thick biofilm experiments relative to control and thin biofilm experiments.

These results suggest that E. coli $\mathrm{O} 157: \mathrm{H} 7$ transport through thick biofilms colonizing porous media may be dualistic, with cells either washed out rapidly through preferential channeling or significantly retarded via interactions with biofilm. This dualistic transport through thick biofilms was also observed by Sharp et al (1999) using porous media reactors and fluorescein dye. This observation is important, as cells which are retarded by biofilm remain in the reactors longer, per pore volume, and may be more likely to be immobilized. 
By colonizing a porous media system with biofilm over three weeks under drinking water conditions, it was possible to retain, over 820 s, up to approximately $9 \%$ of E. coli $\mathrm{O} 157: \mathrm{H} 7$ introduced as a slug dose. Interactions with biofilm within the reactor are believed to have contributed significantly to the degree of pathogen retention. These interactions may be characterized by frequent and occasionally reversible attachment events caused by decreases in average pore size, protection from fluid shear, and an increase in available sorption sites (Stevik et al, 2004). Mechanisms of attachment may include adsorption as well as physical straining or filtration. Factors which may affect the physical straining of pathogens in similar experiments include porous media diameter and pathogen size (Stevik et al, 2004). As mentioned earlier, the frequency and reversibility of adsorption is strongly influenced by the ionic strength of the bulk fluid (Stevik et al, 2004).

It should be noted here that the techniques for measuring pore fluid volumes, and thus calculating retardation factors and plotting breakthrough curves, differed between control (also the non-reactive tracer) and biofilm experiments. Pore fluid volumes were determined for control reactors by measuring the volume of water that was required to fill reactors, thus eliminating any capillary force effects that would be involved in measuring the pore fluid volume by draining filled reactors. Because this was not possible for biofilm-colonized reactors, the pore fluid volumes of these reactors were measured by draining the freely-flowing liquid as described earlier. Some error is expected in these measurements due to pore blockage by biofilm and capillary forces that may prevent fully recovering the entire liquid fraction within the reactor that experienced flux. In 
hindsight, a non-reactive tracer test should have been performed on each reactor, prior to inoculating with E. coli O157:H7, so that hydraulic residence times could be more accurately determined.

\section{Detection and Quantification of E. coli $\mathrm{O} 157: \mathrm{H} 7$}

Enumeration of antibiotic resistant E. coli $\mathrm{O} 157: \mathrm{H} 7$ using plate counting succeeded in closing the mass balance around the reactor. Based on the narrow range of the $95 \%$ confidence interval around $100 \%$ for percent recoveries, this method was considered the standard for analyses. Because experiments typically took about 2 hours to perform and samples were stored on ice following collection, the proliferation of E. coli O157:H7 cells was not considered a source of error in the mass balance.

Direct counts could not be used to close a mass balance on E. coli O157:H7 because CFP-labeled E. coli $\mathrm{O} 157: \mathrm{H} 7$ were indistinguishable in the presence of homogenized biofilm. Homogenized biofilm increased the intensity of background fluorescence and also increased the thickness of material on the polycarbonate filters such that E. coli $\mathrm{O} 157: \mathrm{H} 7$ were distributed over multiple focal planes. Possible explanations for the consistent differences between plate counts and direct counts may include the presence of auto-fluorescent microorganisms in the drinking water as well as E. coli O157:H7 cells that were non-culturable before inoculating but continued to fluoresce (Byrd et al, 1991).

Quantitative PCR is an emerging technique that has the potential to increase specificity and sensitivity while decreasing sampling times for pathogen detection in 
drinking water systems (Lemarchand, 2004). In this study however, qPCR was not as reliable as plate counting for detection or quantification of E. coli $\mathrm{O} 157: \mathrm{H} 7$. Inhibition by biofilm-associated substances may have played a role in the inconsistencies observed in qPCR results as demonstrated in the qPCR inhibition assays (Braid et al, 2003). Investigating additional techniques for increasing the purity of extracted DNA, and further optimizing qPCR protocols, may make it possible to accurately quantify E. coli O157:H7 entrained in biofilm matrices.

In developing the protocols for performing $\mathrm{qPCR}$, it was observed that nonlinearities can exist in the DNA extraction and purification efficiency of E. coli O157:H7 over large ranges of concentration. Consequently, two methods for creating standard curves were used (as described earlier): 1) DNA was extracted/purified from multiple samples created by serially diluting a sample with a known concentration of $E$. coli O157:H7, and 2) A single extraction/purification was performed on a sample with a known concentration of $E$. coli $\mathrm{O} 157: \mathrm{H} 7$, and the resulting genomic DNA was then diluted. The latter method would inherently remove nonlinearities created during DNA extraction and purification that could result in artifacts in downstream analyses. In summary, well-purified DNA along with carefully constructed standard curves are prerequisite for acquiring quantitative information from PCR-based techniques.

These experiments corroborate observations from previous studies regarding microbial transport through biofilms growing in pilot-scale and laboratory-scale distribution systems. Cryptosporidium oocysts (Searcy et al, 2006), Escherichia coli (Banning et al, 2003; Camper et al, 1996; Li et al, 2006), Pseudomonas aeruginosa 
(Banning et al, 2003), Helicobacter (Mackay et al, 1998), Mycobacterium (September et al, 2004), Legionella (Längmark et al, 2005; Liu et al, 2006; Rogers et al, 1984), and coliforms (Camper et al, 1991; McMath et al, 1999) have all been demonstrated to concentrate in drinking water biofilms relative to the bulk fluid. While these studies explored biofilm-pathogen interactions as a possible source of prolonged contamination, the data supports the concept of using biofilm as a capture mechanism for waterborne pathogens. Based on these observations and the data presented in this study, it may be feasible to use porous media 'biofilm traps' as novel monitoring tools for drinking water distribution systems. 


\section{CONCLUSIONS}

- Porous media biofilm reactors, colonized with biofilm under drinking water conditions, retained significantly more E. coli $\mathrm{O} 157: \mathrm{H} 7$ than clean control reactors

- This has implications in distribution system monitoring as currently the Total Coliform Rule only requires sampling for waterborne coliforms

- The retardation of $E$. coli $\mathrm{O} 157: \mathrm{H} 7$ which passed through reactors, caused by biofilm, prolonged washout

- Engineered porous media systems, acting as a substrate for the colonization of biofilm in drinking water distribution systems, may be a feasible and novel tool for monitoring and detecting the contamination of water supplies by human pathogens 


\section{REFERENCES}

http://depts.washington.edu/bakerpg/electrocompetent.html

www.epa.gov/safewater/disinfection/tcr/regulation_revisions.html

Abbott, A., Rutter, P.R., Berkeley, R.C.W. (1983) The influence of ionic strength, pH, and a protein layer on the interaction between Streptococcus mutans and glass surfaces. J. Gen. Microb. 129, 439-445.

Ames, M. H., Webster, J. T. (1991). On estimating approximate degrees of freedom,. American Statistician. 45, 45-50.

Banning, N., Toze, S., Mee, B.J. (2003) Persistence of biofilm-associated Escherichia coli and Pseudomonas aeruginosa in groundwater and treated effluent in a laboratory model system. Society for General Microb. 149, 47-55.

Beech, I.B. (2004) Corrosion of technical materials in the pesence of bofilms: Current understanding and state-of-the-art methods of study. International Biodeterioration \& Biodegradatoin. 53, 177-183.

Bjergbaek, L.A., Roslev, P. (2005) Formation of nonculturable Escherichia coli in drinking water. J. Appl. Microb. 99, 1090-1098.

Braid, M.D., Daniels, L.M., Kitts, C.L. (2003) Removal of PCR inhibitors from soil DNA by chemical flocculation. J. Microb. Methods. 52, 389-393.

Byrd, J.J., Xu H.S., Colwell, R.R. (1991) Viable but nonculturable bacteria in drinkingwater. Appl. \& Eniviron. Microb. 57, 875-878.

Camper, A.K., Jones, W.L., Hayes, J.T. (1996) Effect of growth conditions and substratum composition on the persistence of coliforms in mixed-population biofilms. Appl. Environ. Microb. 62, 4014-4018.

Camper, A.K., Mcfeters, G.A., Characklis, W.G., Jones, W.L. (1991) Growth-kinetics of coliform bacteria under conditions relevant to drinking-water distribtion-systems. Appl. Environ. Microb. 57, 2233-2239.

Costerton, J.W. (1984) The etiology and persistence of cryptic bacterial infections a hypothesis. Rev. Infect Dis. 6, 608-616.

Costerton, J.W. (1995) Overview of microbial biofilms. J. Ind. Microb. 15, 137-140. 
Cunningham, A.B., Characklis, W.G., Abedeen, F., Crawford, D. (1991) Influence of biofilm accumulation on porous-media hydrodynamics. Eviron. Sci. \& Tech. 25, 13051311.

Davey, T. (2005) Jail sentence follows Walkerton saga. Environ.Sci. \& Eng.

Dunsmore, B.C., Bass, C.J., Lappin-Scott, H.M. (2004) A novel approach to investigate biofilm accumulation and bacterial transport in porous matrices. Envirion. Microb.6, 183187.

Ellwood, D.C., Deevil, C.W., Marsh, P.D., Brown, C.M., Wardell, J.N. (1982) Surfaceassociated growth. Philos Tans R Sco London. 297, 517-532.

Fletcher, M., Floodgate, G.D. Electron-microscope demonstration of an acidic polysaccharide involved in the adhesion of marine bacterium to solid surfaces. J. Gen. Microb. 74, 325-334.

Gilbride, K.A., Lee D.Y., Beaudette, L.A. (2006) Molecular techniques in wastewater: Understanding microbial communities, detecting pathogens, and real-time process control. J. Microb. Methods. 66, 1-20.

Government Accountability Office (GAO-04-1098T Drinking Water Security). (2004) Drinking water: Experts' views on how federal funding can best be spent to improve security.

Harwood, V.J., Levine, A.D., Scott, T.M., Chivukula, V., Lukasik, J., Farrah, S.R., Rose, J.B. (2005) Validity of the indicator organism paradigm for pathogen reduction in reclaimed water and public health protection. Appl. Environ. Microb. 71, 3163-3170.

Jewett, D.G., Hilbert, T.A., Logan, B.E., Arnold, R.G. Bales, R.C. (1995) Bacterial transport in laboratory columns and filters: Influence of ionic strength and $\mathrm{pH}$ on collision efficiency. Water Res. 29, 1673-1680.

Johnson, W.P., Cabral, K., Lion, L.W., Corapcioglu, Y.M. (1998) Reconciliation of expressions for the modified retardation factor and incorporation of non-linear contaminant sorption to the stationary phase. J. Contam. Hydrology. 32, 247-266.

Längmark, J., Storey, M.V., Ashbolt, N.J., Stenström, T. (2005) Accumulation and fate of microorganisms and microspheres in biofilms formed in a pilot-scale water distribution system. Appl. Environ. Microb. 71, 706-712.

LeChevallier, M.W., Babcock, T.M., Lee, R.G. (1987) Examination and characterization of distribution system biofilms. Appl. Environ. Microb. 53, 2714-2724. 
Lemarchand, K., Masson, L., Brousseau, R. (2004) Molecular biology and DNA microarray technology for microbial quality monitoring of water. Crit. Rev. in Microb. $30,145-172$.

Li, J., McLellan, S., Oyawa, S. (2006) Accumulation and fate of green fluorescent labeled Escherichia coli in laboratory-scale drinking water biofilters. Water Res. 40, 3023-3028.

Lim, D.V., Simpson, J.M., Kearns, E.A., and Kramer, M.F. (2005) Current and developing technologies for monitoring agents of bioterrorism and biowarfare. Clin. Microb. Rev. 18, 583-607.

Liu, Z., Lin, Y.E., Stout, J.E., Hwang, C.C., Vidic, R.D., Yu, V.L. (2006) Effect of flow regimes on the presence of Legionella within the biofilm of a model plumbing system J. Appl. Microb. 101, 437-442.

Mackay, W.G., Gribbon, L.T., Barer. M.R., Reid, D.C. (1998) Biofilms in drinking water sytsems - A possible reservoir for Helicobacter Pylori. Water Science Tech. 38, 181-185.

McMath, S.M., Sumpter, C., Holt, D.M., Delanoue, A., Chamberlain, A.H.L. (1999) The fate of environmental coliforms in a model water distribution system. Letters in Appl. Microb. 28, 93-97.

National Research Council (NRC). (2006) Drinking water distribution systems: Assessing and reducing risks. Committee on Public Water Supply Distribution Systems.

Okabe, S., Kuroda, H., Watanabe, Y. (1998) Significance of biofilm structure on transport of inert particles into biofilms. Water Science Tech. 38, 163-170.

Roberts M.E., Stewart P.S. (2005) Modelling protection from antimicrobial agents in biofilms through the formation of persister cells. Microb.-SGM. 151, 75-80.

Searcy, K.E., Packman, A.I., Atwill, E.R., Harter, T. (2006) Capture and retention of Cryptosporidium parvum oocysts by Psuedomonas aeruginosa biofilms. Appl. Environ. Microb. 72, 6242-6247.

September, S.M., Brözel, V.S., Venter, S.N. (2004) Diversity of nontuberculoid Mycobacterium species in biofilms of urban and semiurban drinking water distribution systems. Appl. Environ. Microb. 70, 7571-7573.

Sharma, M.M., Chang, Y.I., Yen, T.F. (1985) Reversible and irreversible surface charge modification of bacteria for facilitating transport through porous media. Colloids Surf. 16, 193-206. 
Sharma, V.K., Dean-Nystrom, E.A. (2003) Detection of enterohemorrhagic Escherichia coli O157:H7 by using a multiplex real-time PCR assay for genes encoding intimin and shiga toxins. Veterinary Microb. 93, 247-260.

Sharp, R.R., Stoodley, P., Adgie, M. (2005) Visualization and characterization of dynamic patterns of flow, growth and activity of biofilms growing in porous media. Water Sci. \& Tech. 52, 85-90.

Sharp, R.R., Cunningham, A.B., Komlos, J., Billmayer, J. (1999) Observation of thick biofilm accumulation and structure in porous media and corresponding hydrodynamic and mass transfer effects Water Science Tech. 39, 195-201.

Siragusa, G.R., Nawotka, K., Spilman, S.D., Contag, P.R., Contag, C.H. (1999) Realtime monitoring of Escherichia coli O157: H7 adherence to beef carcass surface tissues with a bioluminescent reporter. Appl. Environ. Microb. 65, 1738-1745.

Stevik, T.K., Aa, K. Ausland, G., Hanssen, J.F. (2004) Retention and removal of pathogenic bacteria in wastewater percolating through porous media: A Review. Water Res. 38, 1355-1367.

Stewart P.S., Hamilton M.A., Goldstein B.R., Schneider, B.T. (1996) Modeling biocide action against biofilms. Biotech. \& Bioengin. 49, 445-455.

Tiwari, S.K., Bowers, K.L. (2001) Modeling biofilm growth for porous media applications. Mathematical \& Computer Modelling. 33, 299-319. 
APPENDICES 
$\underline{\text { APPENDIX A }}$

ADDITIONAL DIRECT COUNT DATA 


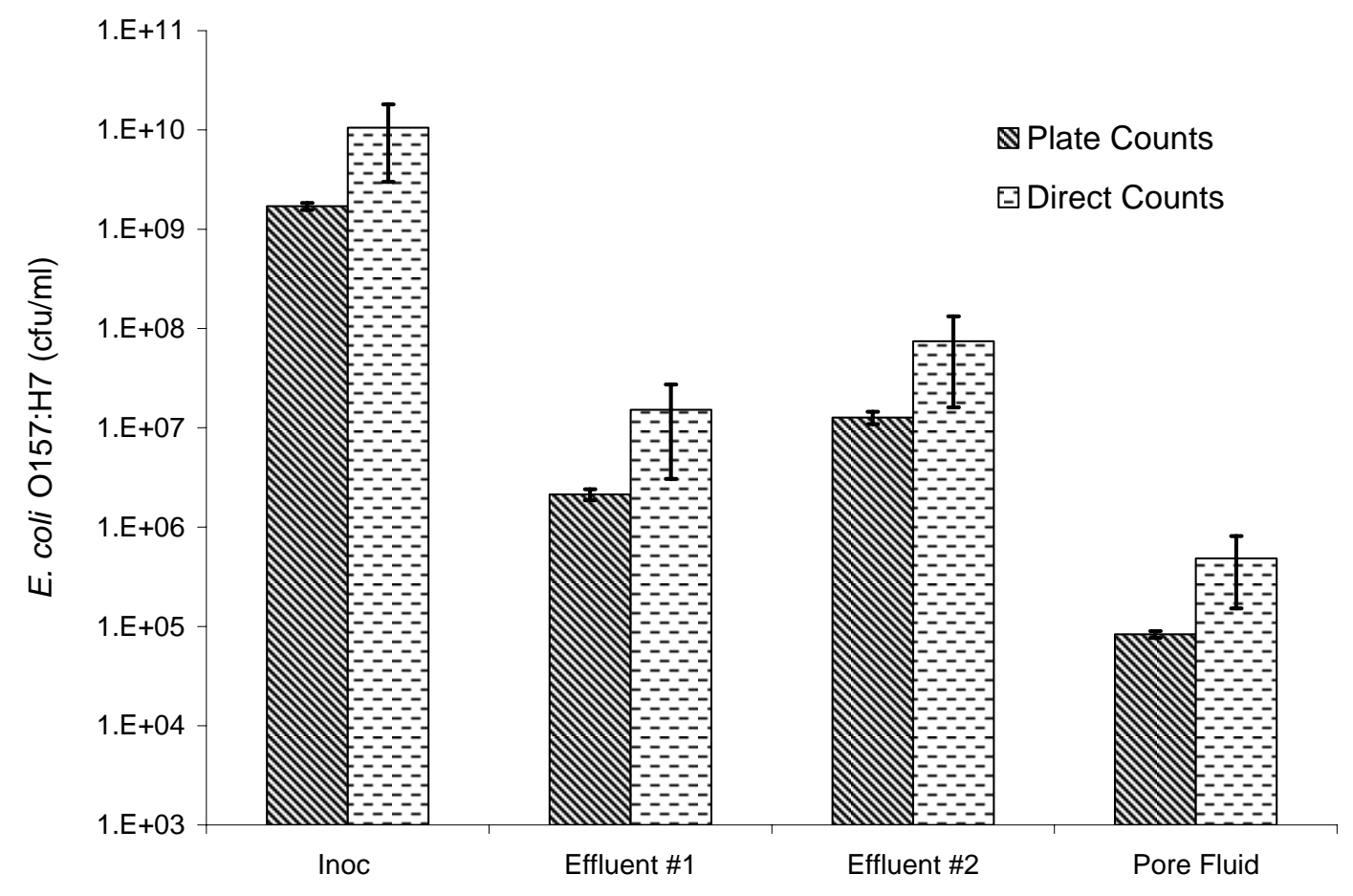

Figure A1. Plate counts compared with direct counts for control experiment \#6

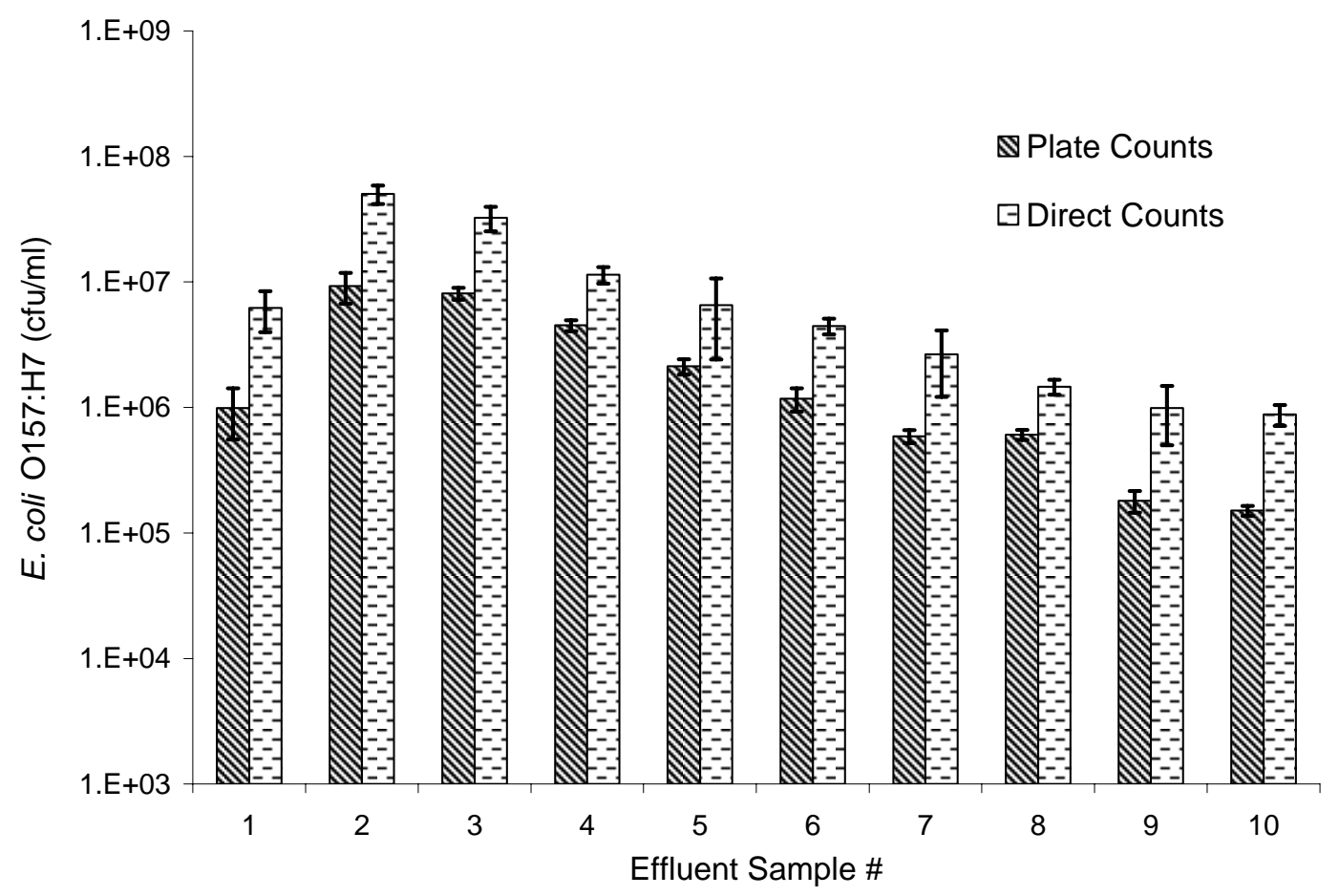

Figure A2. Plate counts compared with direct counts for thin biofilm experiment \#2 


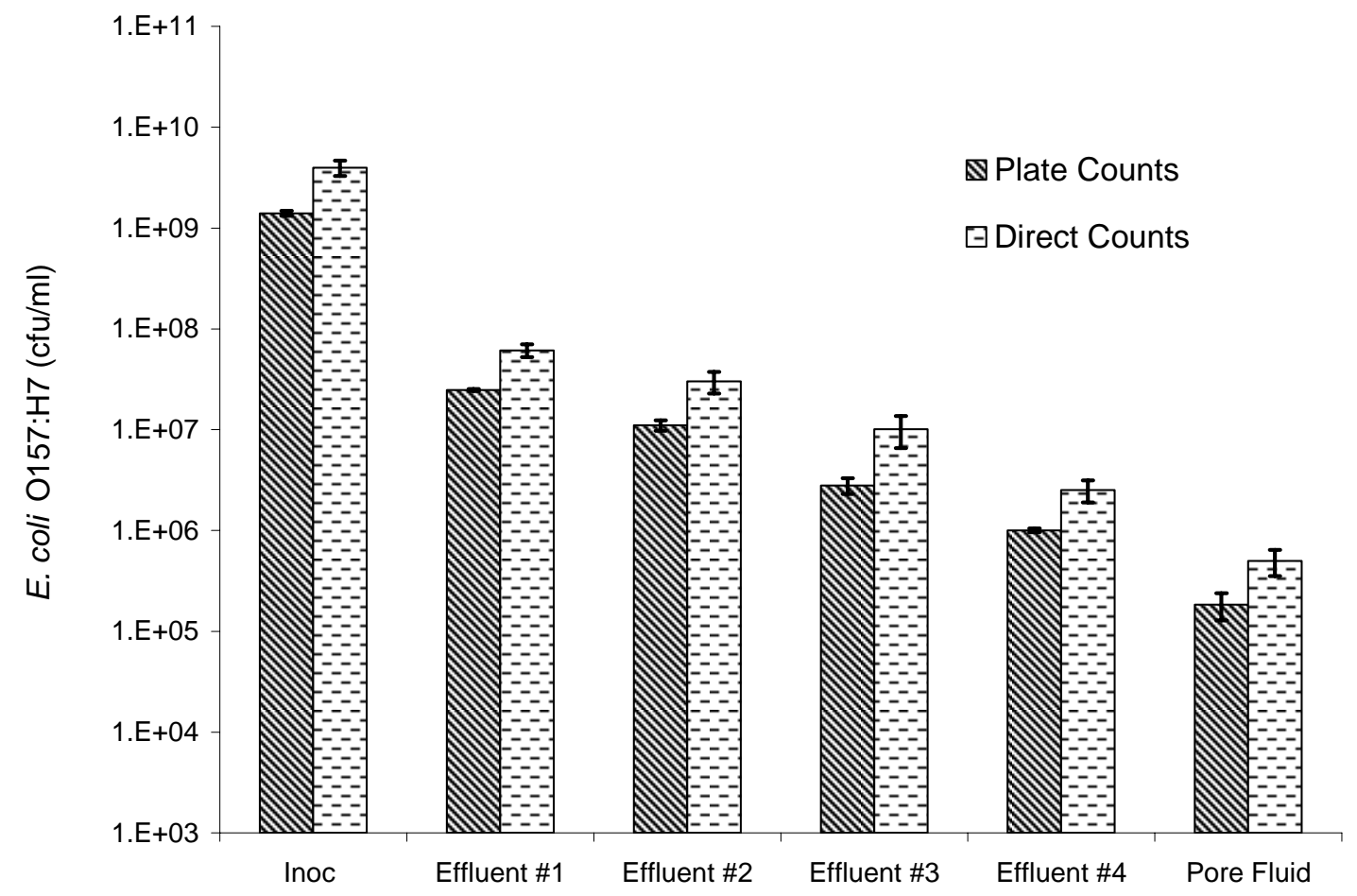

Figure A3. Plate counts compared with direct counts for thick biofilm experiment \#1 
$\underline{\text { APPENDIX B }}$

ADDITIONAL QUANTITATIVE PCR DATA 


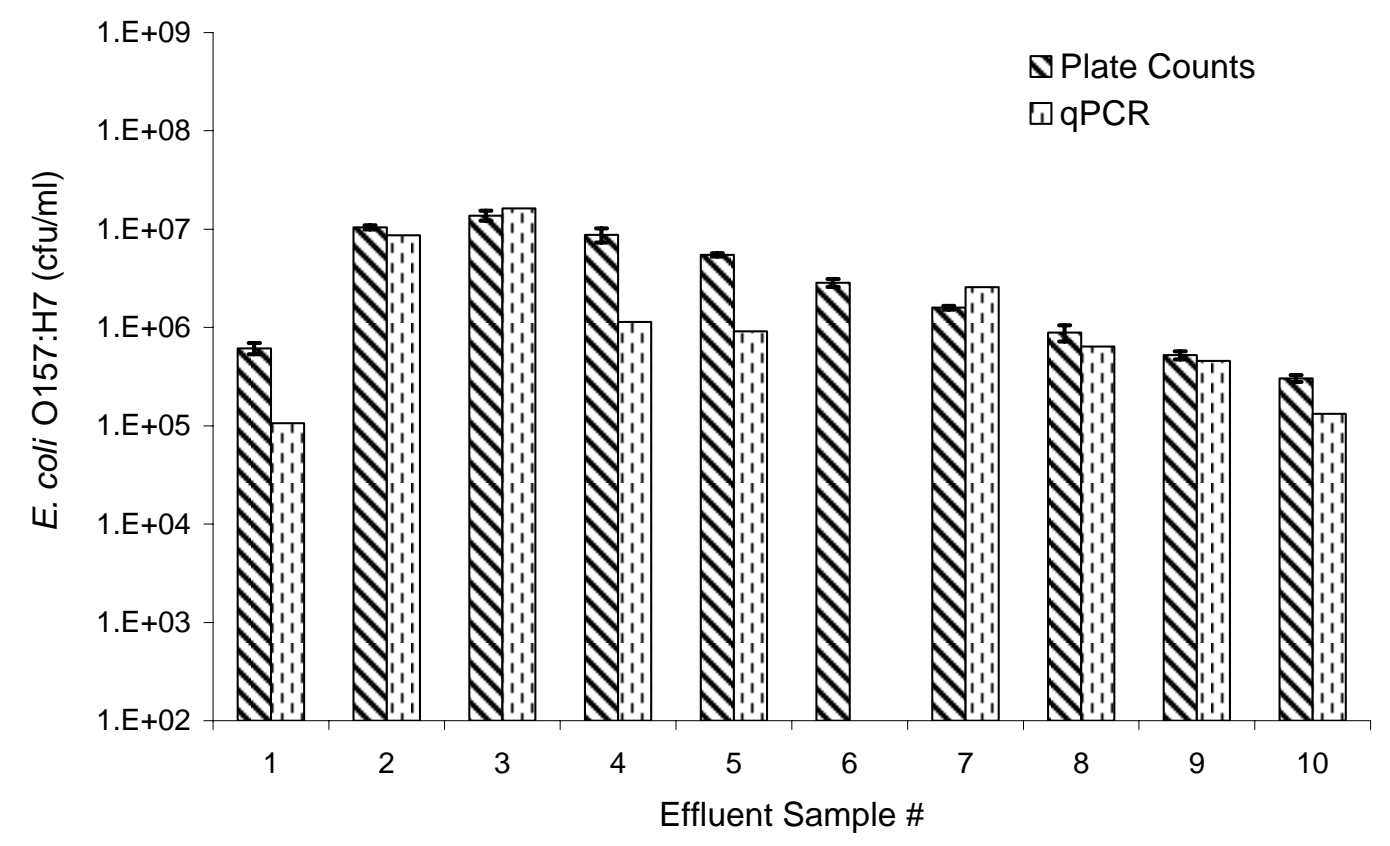

Figure B1. Plate counts compared with qPCR for effluent samples from control experiment \#1

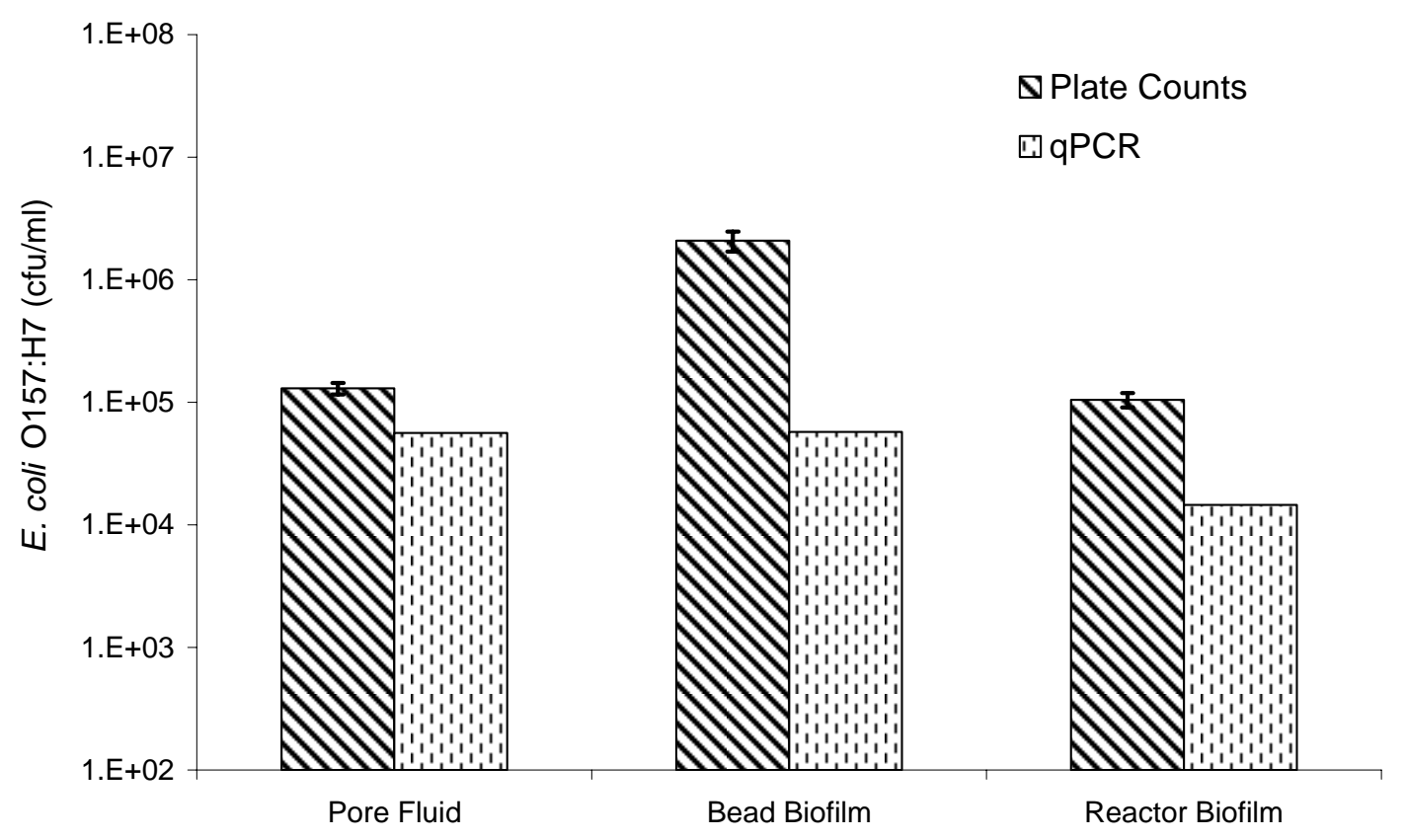

Figure B2. Plate counts compared with qPCR for control experiment \#1 


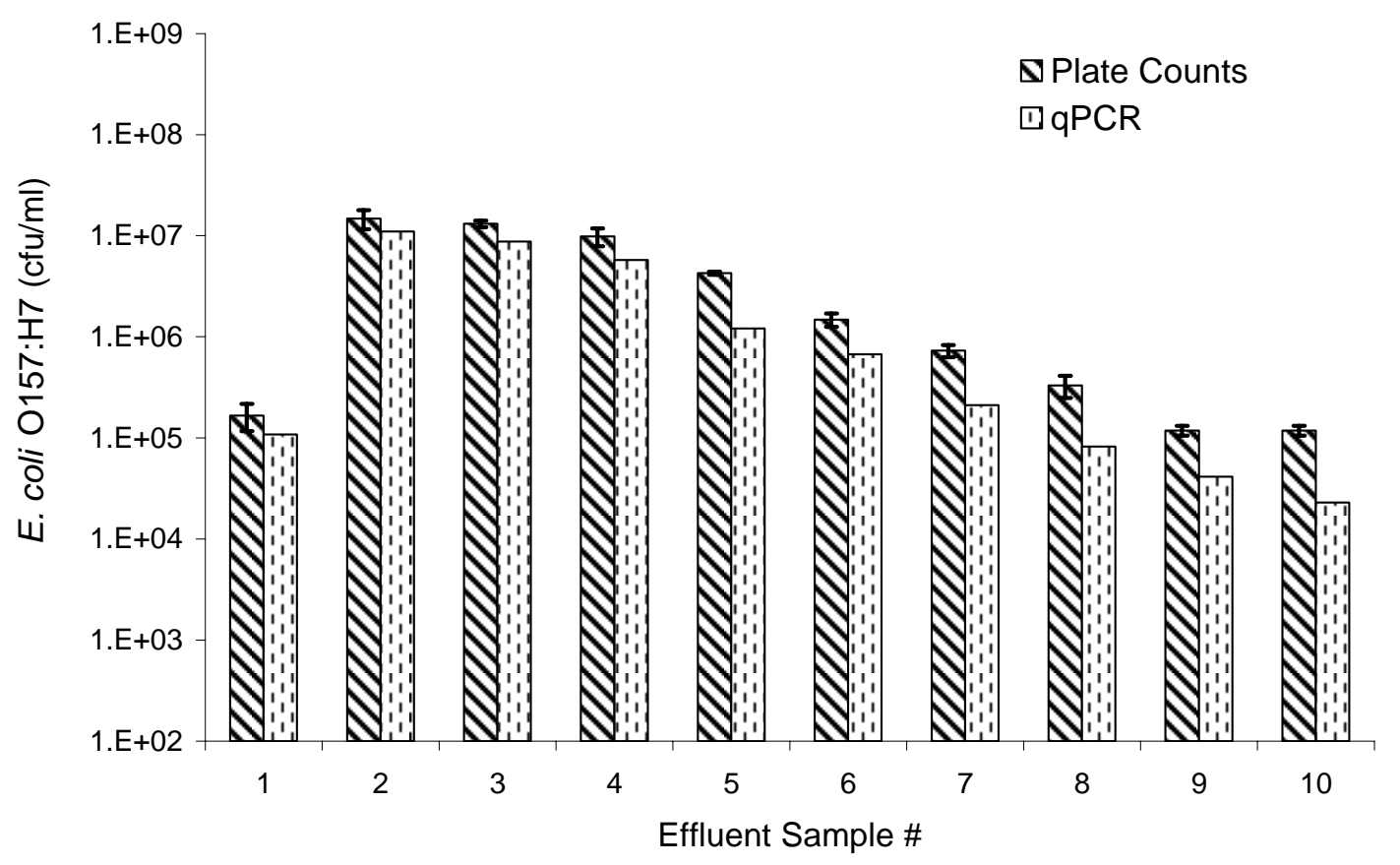

Figure B3. Plate counts compared with qPCR for effluent samples from control experiment \#3

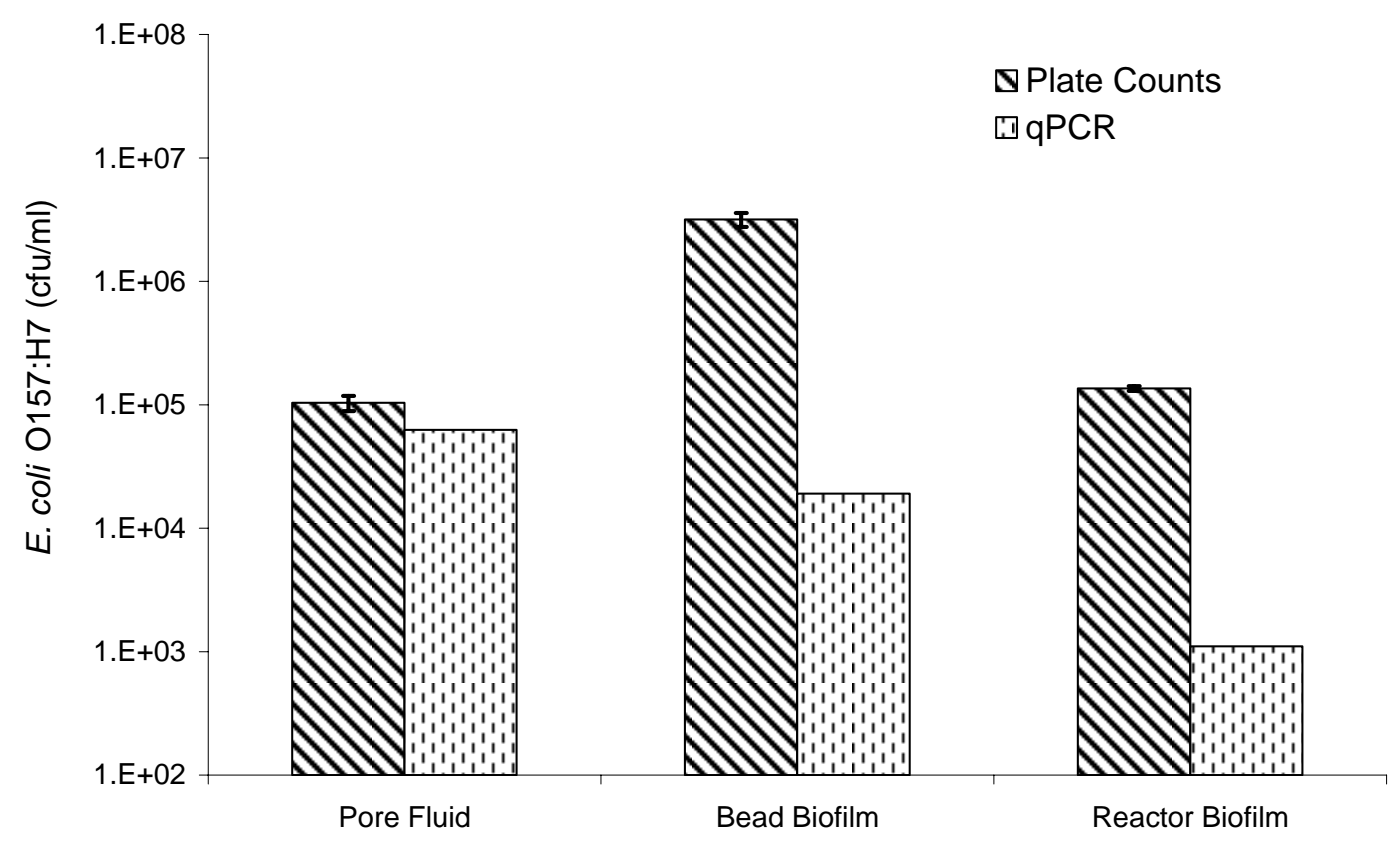

Figure B4. Plate counts compared with qPCR for control experiment \#3 


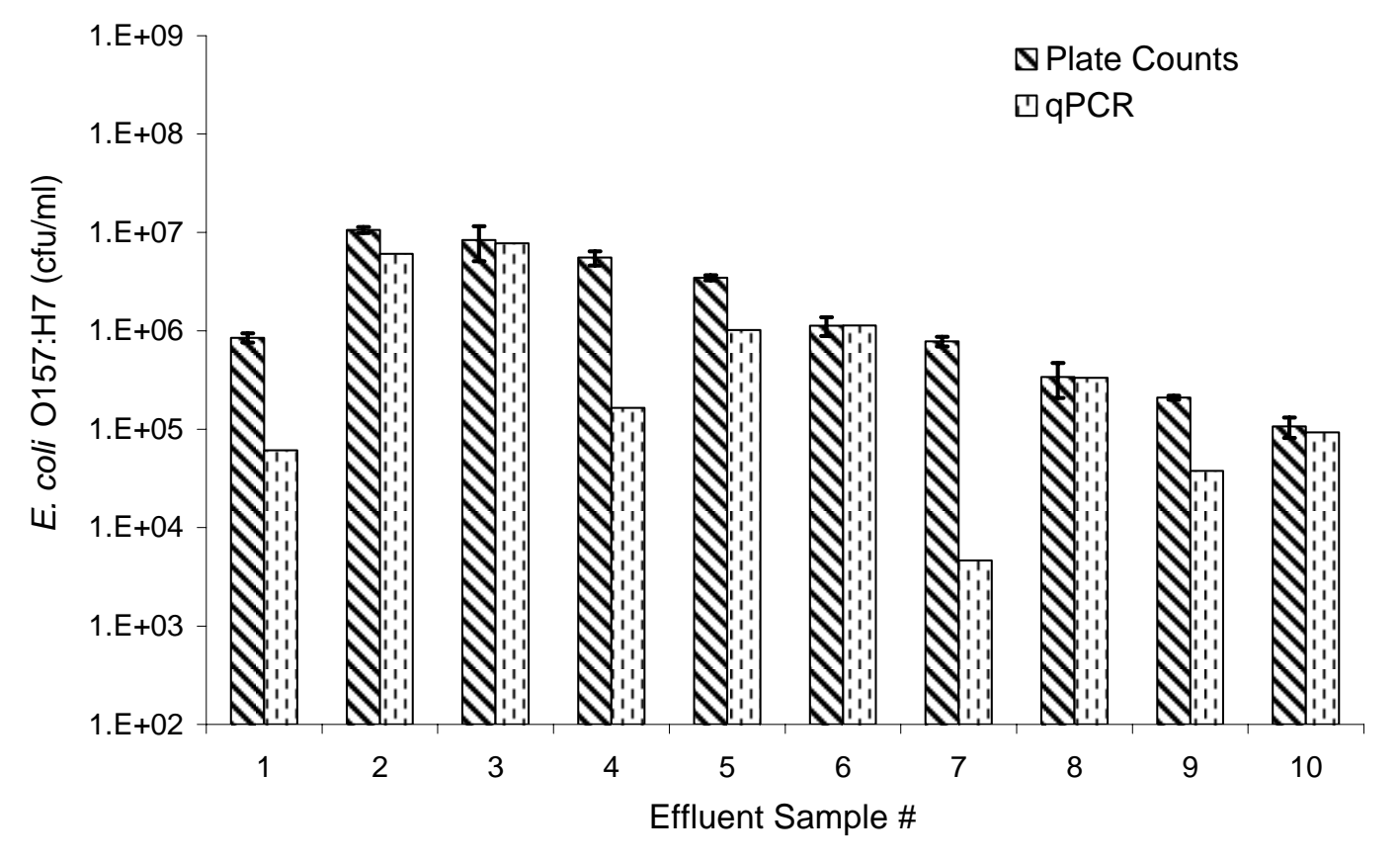

Figure B5. Plate counts compared with qPCR for effluent samples from control experiment \#7

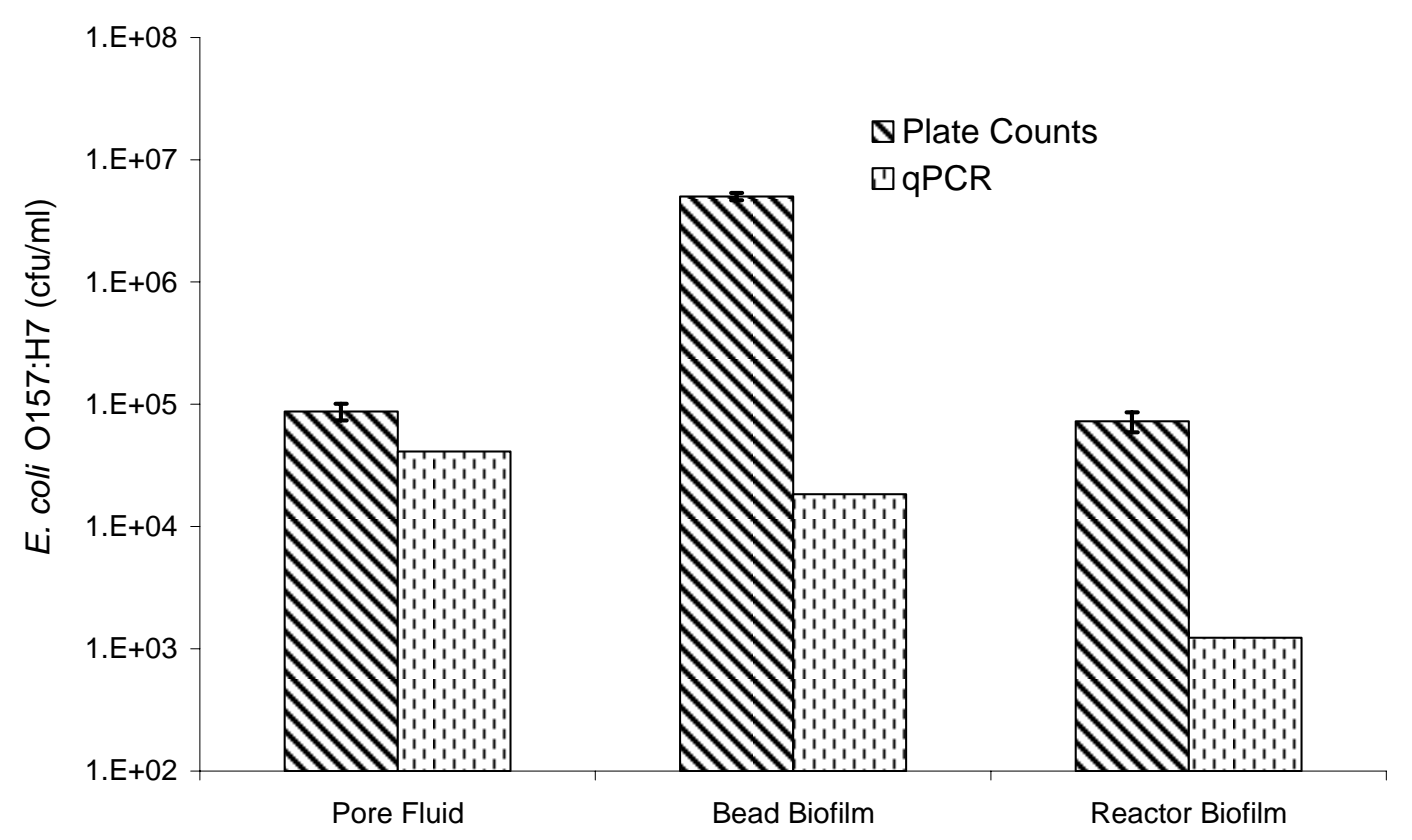

Figure B6. Plate counts compared with qPCR for control experiment \#7 


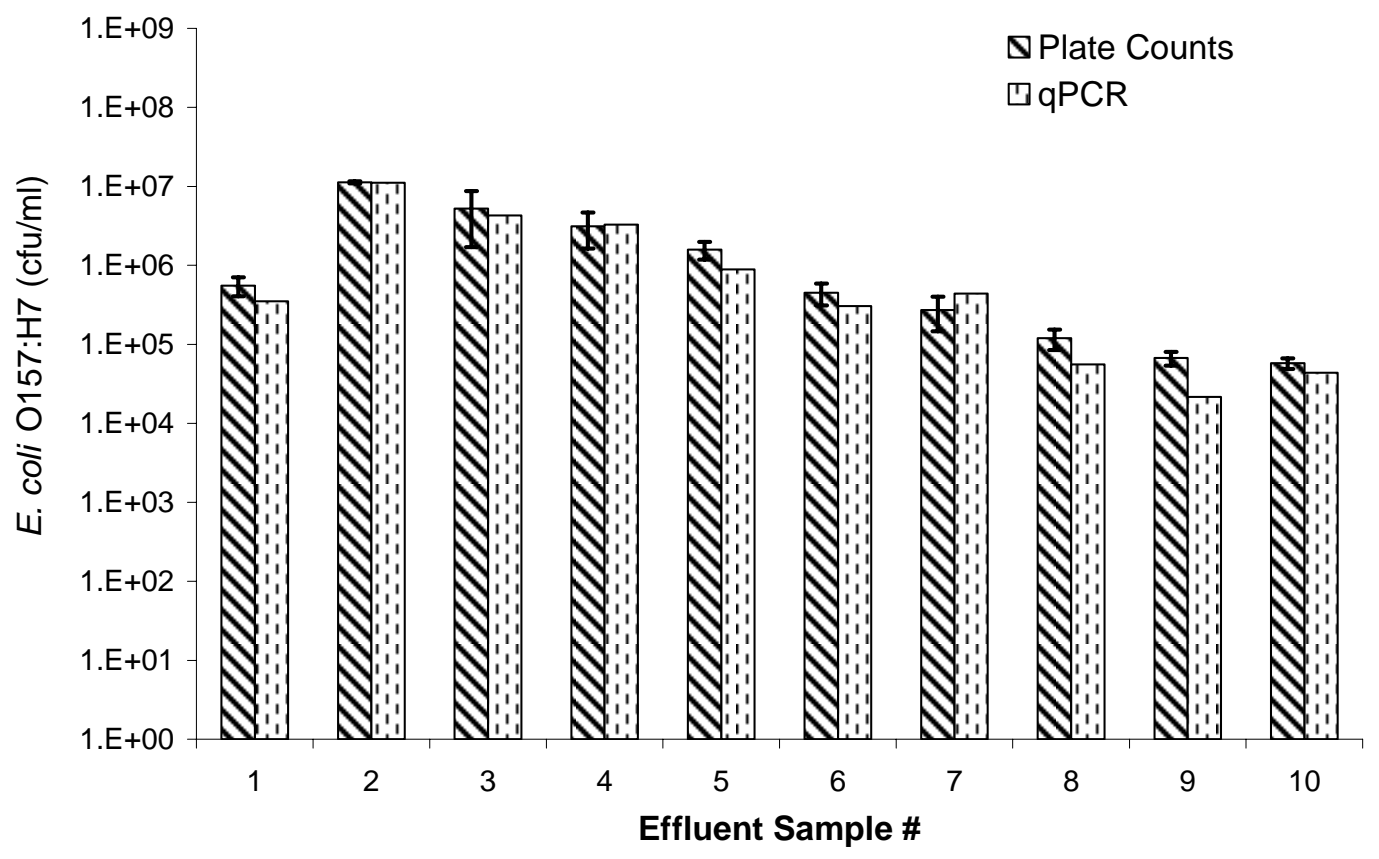

Figure B7. Plate counts compared with qPCR for effluent samples from thin biofilm experiment \#1

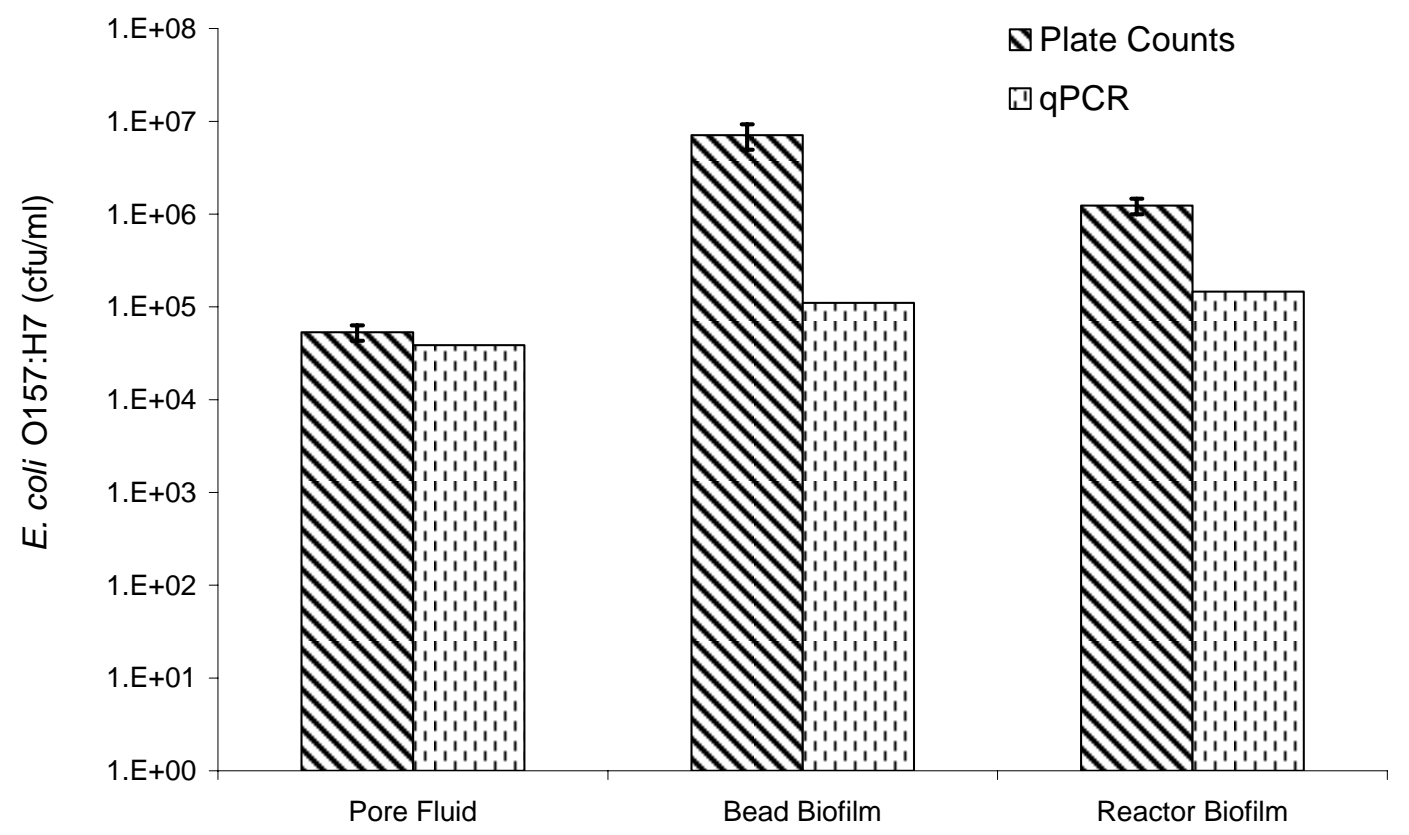

Figure B8. Plate counts compared with qPCR for thin biofilm experiment \#1 


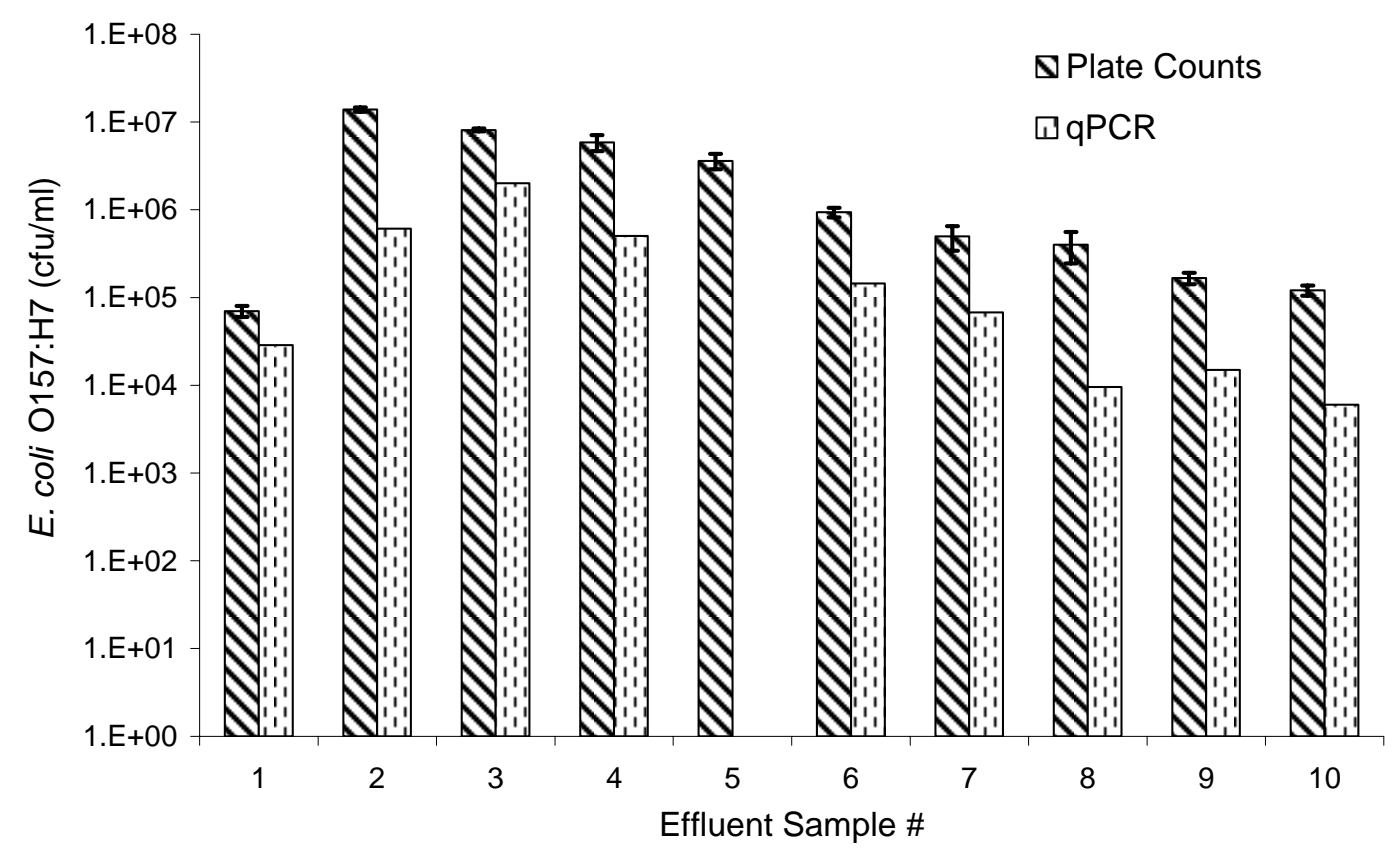

Figure B9. Plate counts compared with qPCR for effluent samples from thin biofilm experiment \#3

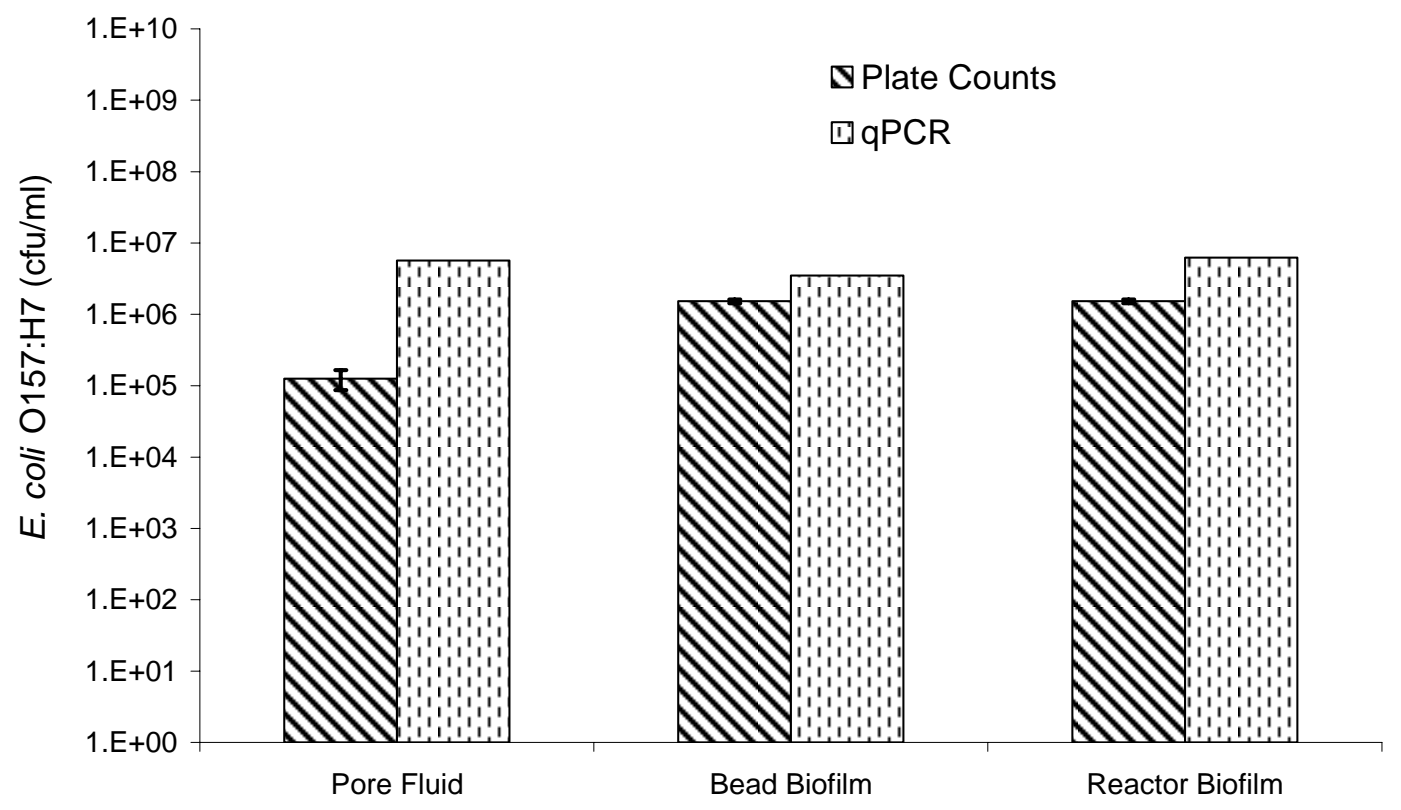

Figure B10. Plate counts compared with qPCR for thin biofilm experiment \#3 


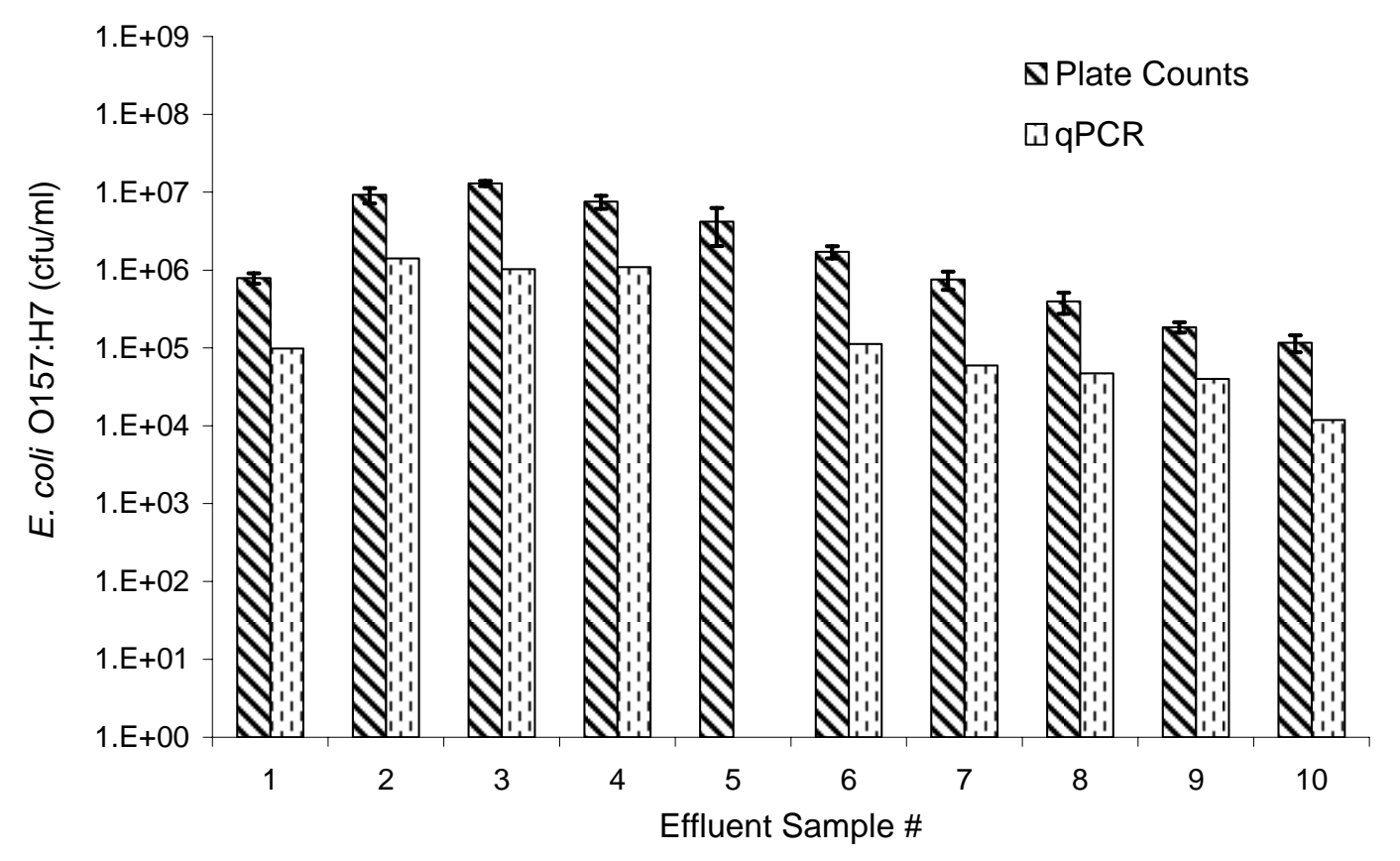

Figure B11. Plate counts compared with qPCR for effluent samples from thin biofilm experiment \#4

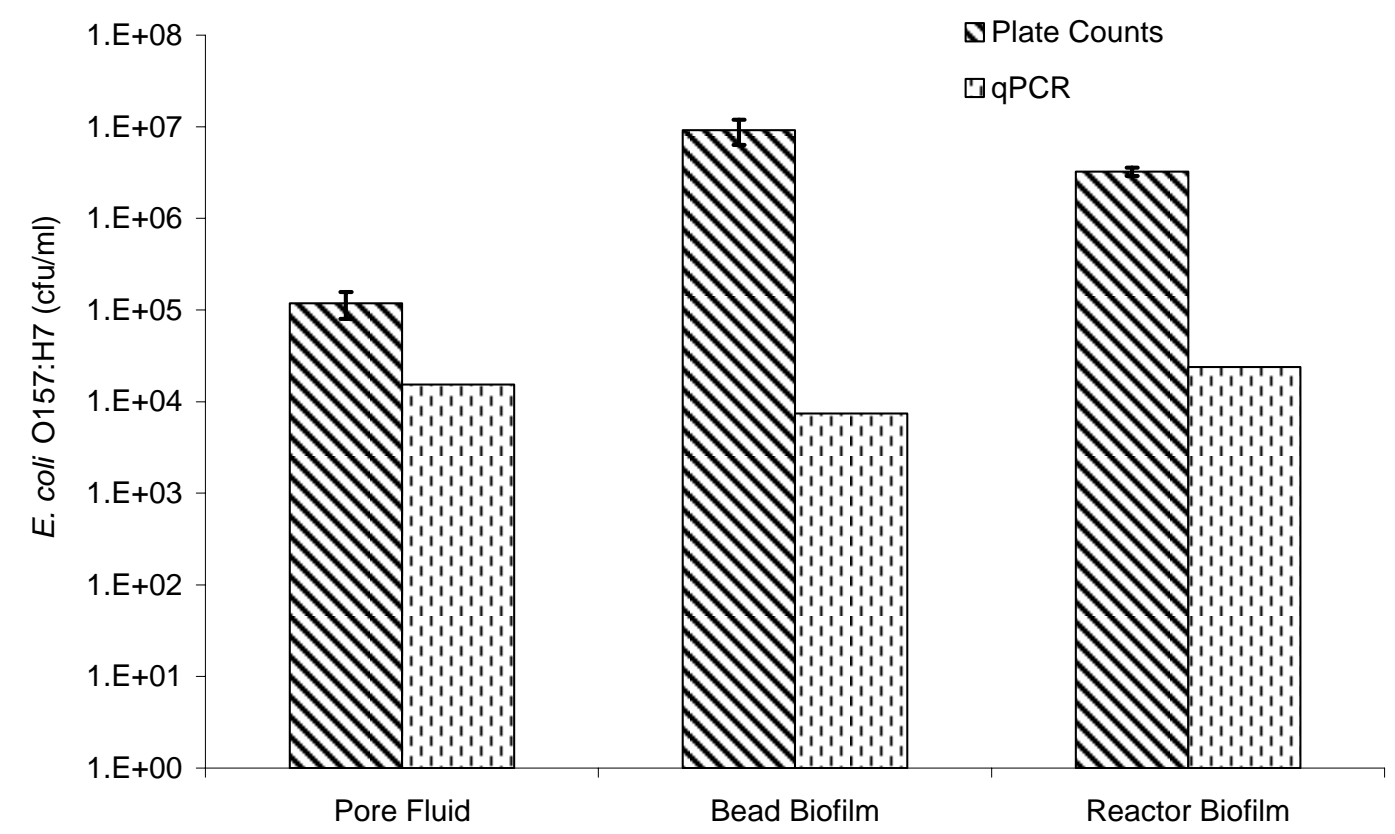

Figure B12. Plate counts compared with qPCR for thin biofilm experiment \#4 


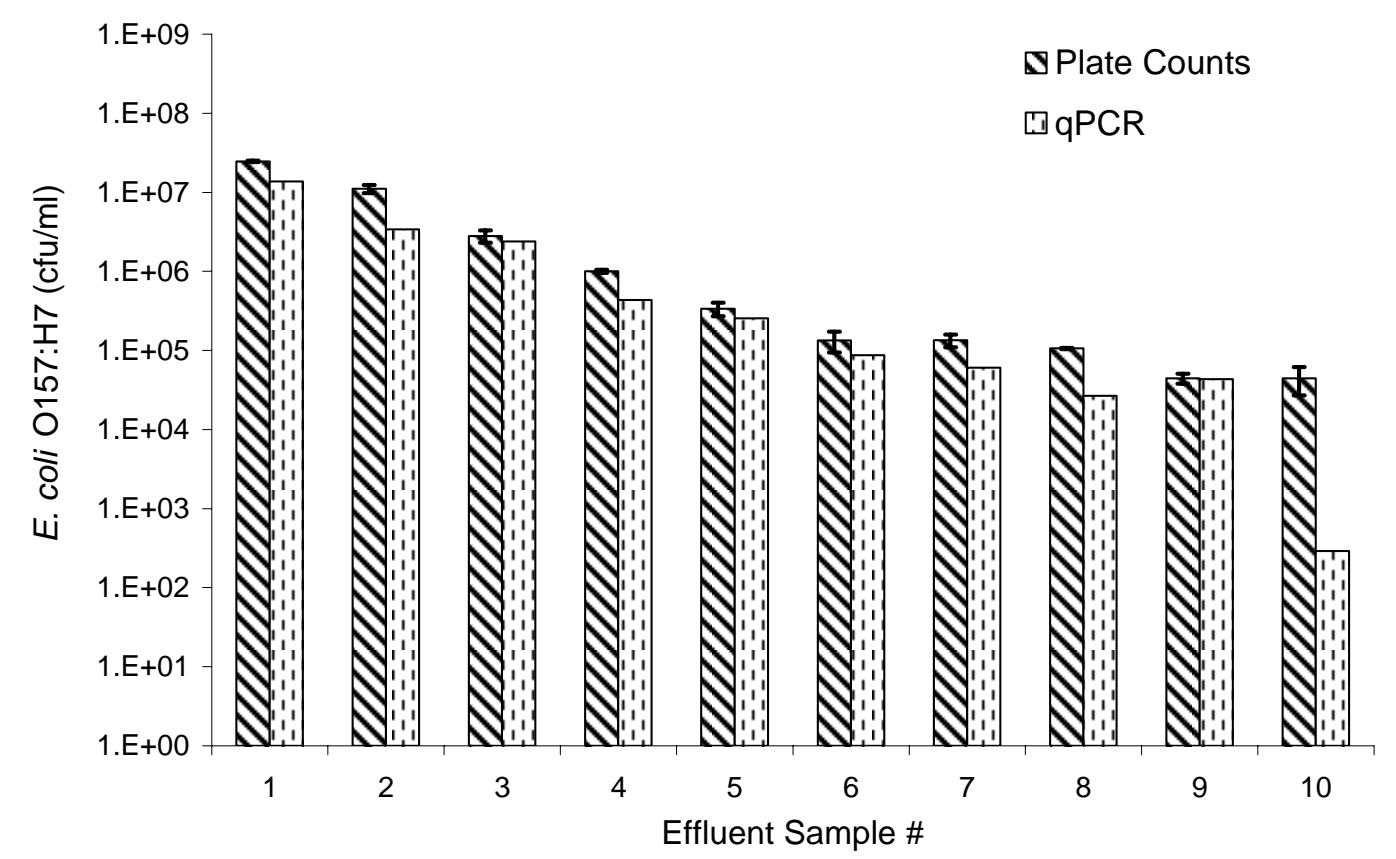

Figure B13. Plate counts compared with qPCR for effluent samples from thick biofilm expeirment \#1

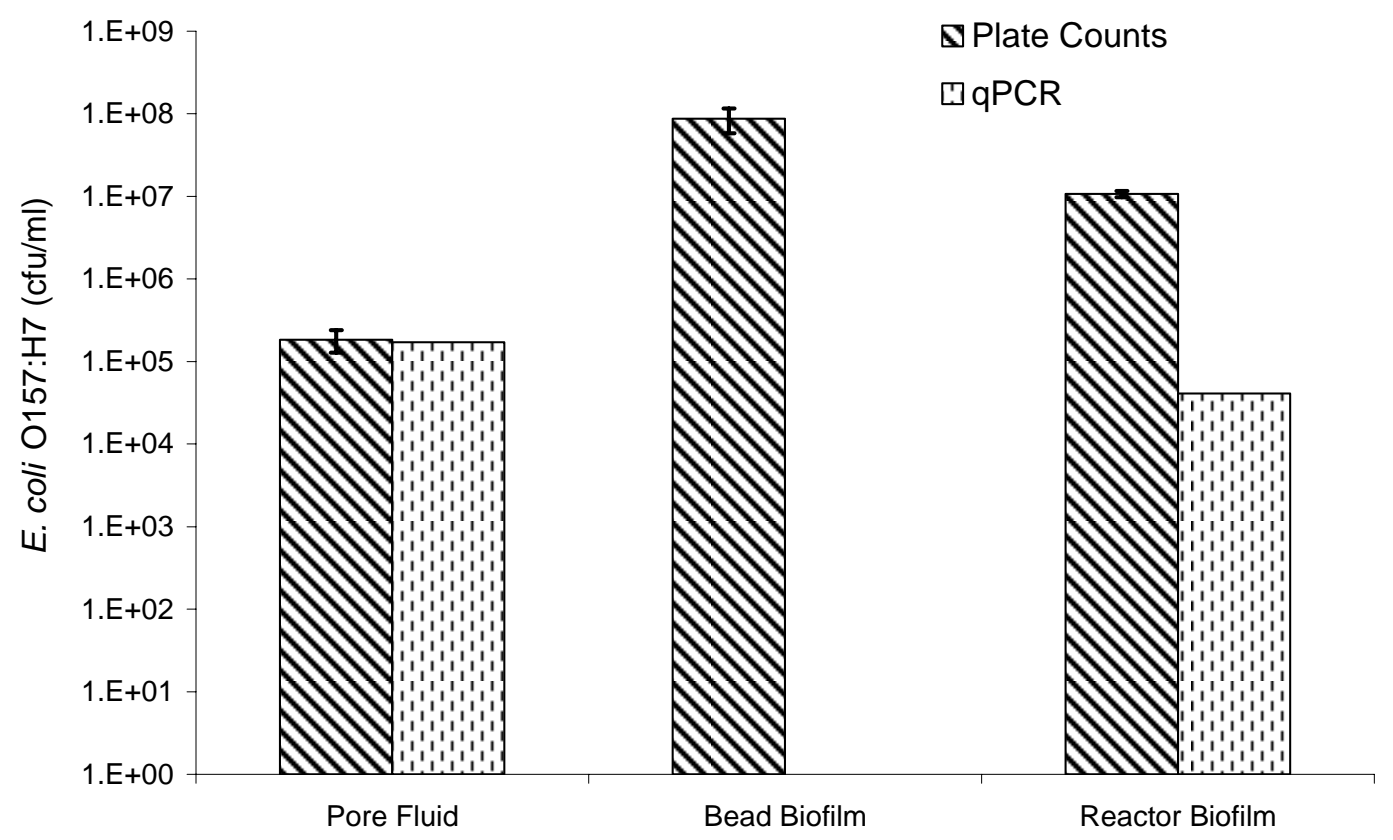

Figure B14. Plate counts compared with qPCR for thick biofilm experiment \#1 